GEOLOGIC DATA COLLECTED AND ANALYTICAL

PROCEDURES USED DURING A GEOCHEMICAL

INVESTIGATION OF THE UNSATURATED ZONE,

RADIOACTIVE WASTE MANAGEMENT COMPLEX,

IDAHO NATIONAL ENGINEERING LABORATORY, IDAHO

by C.T. Rightmire and B.D. Lewis

U.S . GEOLOGICAL SURVEY

Open-File Report 87-246

Prepared in cooperation with the

U.S. DEPARTMENT OF ENERGY

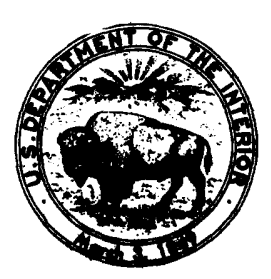

Idaho Falls, Idaho

September 1987 
DEPARTMENT OF THE INTERIOR

DONALD PAUL HODEL, Secretary

U.S. GEOLOGICAL SURVEY

Dallas L. Peck, Director

For additional information write to:

Project Office

U.S. Geological Survey

P.O. Box 2230

INEL, CF-690, Room 164

Idaho Falls, Idaho 83403-2230
Copies of this report can be purchased from:

Books and Open-File Reports Section Western Distribution Branch Box 25425, Federal Center Denver, CO 80225

Telephone: (303) 234-5888 
Abstract . . . . . . . . . . . . . . . . . . 1

Introduction . . . . . . . . . . . . . . . . . . . . . . . . . . 1

Purpose and scope . . . . . . . . . . . . . . . . . . . . . 3

Previous investigations . . . . . . . . . . . . . . . . . . 5

Acknowledgments . . . . . . . . . . . . . . . . . . 5

Generalized geology. . . . . . . . . . . . . . . . . . . . 6

Core sample descriptions . . . . . . . . . . . . . . . . . . . . 8

Wel1 76-1........................ . 9

Well 76-2....................... . 15

Well 76-3......................... 19

Wel1 76-4... . . . . . . . . . . . . . . . . . . . . . 26

Well 76-4A. . . . . . . . . . . . . . . . . . . 30

We11 76-5....................... . 35

Well 76-6.......................... 44

Well 77-2........................ . 53

Thin-section analyses. . . . . . . . . . . . . . . . . . . . . . 59

Well 76-1...................... 59

We11 76-2....................... 63

We11 76-3... ...................... 63

We11 76-4 and 76-4A.... . . . . . . . . . . . . . . . 64

EWR subpit samples. . . . . . . . . . . . . . . . . . . 67

Scanning electron microscopy. . . . . . . . . . . . . . . . 67

Analytical Procedures. . . . . . . . . . . . . . . . . . . 70

Geochemical use of stable isotope data. . . . . . . . . . 72

Standards and $\delta$ notation. . . . . . . . . . . . . . . 73

Fractionation factors . . . . . . . . . . . . . . . . 74

Natural fractionation . . . . . . . . . . . . . . . 75

Paleotemperature determinations . . . . . . . . . . . . . . 79

X-ray analyses. . . . . . . . . . . . . . . . . . . . 80

Isotope analyses. . . . . . . . . . . . . . . . . . . . . . 80

Summary. . . . . . . . . . . . . . . . . . . . . . . . . . . . . 81

References . . . . . . . . . . . . . . . . 82

\section{IILUSTRATIONS}

Figure 1. Location of the INEL and eastern Snake River Plain, and the relationship of the RWMC and adjacent wells to the diversion areas and the Big Lost River (from Rightmire, 1984). . · · · ·

2. Location of wells and waste disposal pits and trenches at the RWMC.

3. Photograph of a thin section from sample $76-1-i$, showing a basalt-sedimentary contact in a fracture located at $26.21 \mathrm{~m}$ in well $76-1 . \cdot \dot{H}^{\circ} \cdot \dot{j} \cdot \dot{b}^{\cdot}$

4. Photograph of a thin section from sample 76-1-3(b), showing replacement of secondary silica by laterstage secondary carbonate

5. Photograph of a thin section from sample 76-3-il(b), showing cross-bedded(?) clay material in a fracture located at $25.15 \mathrm{~m}$ in well 76-3 
6. Photograph of a portion of the thin figure 5 , showing small opaque particles within the clay. . . . . . . . . . . . . . . . . . . . . 66

7. SEM photograph of sample 76-1-4(c), showing clay platelets (smectite) surrounded by calcite crystals on the upper surface of a fracture located at

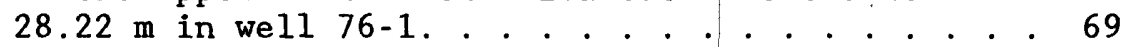

8. SEM photograph of sample 76-1-6(c), showing a white stalactitic growth, composed of smectite or calcite plus clay, at $29.00 \mathrm{~m}$ in well 76-1. . . . . . . . . 69

9. SEM photograph of sample 93A-1B-1, showing calcite and clay material lining a fracture at $7.41 \mathrm{~m}$ in well 93A.................... . 71

10. SEM photograph of sample 93A-1B-2, showing a clay platelet on top of small crystals from the same sampling locality as depicted in figure 9... . 71

\section{TABLE}

Table 1. Depths to tops and bottoms, and thicknesses (in meters) of sedimentary units in wells at the RWMC . . . . . 7

FACTORS FOR CONVERTING METRIC (SI) UNITS TO INCH-POUND UNITS

The following factors can be used to convert the International system (SI) of metric units published herein to inch-pound units.

Multiply metric units

centimeter $(\mathrm{cm})$

meter (m)

kilometer $(\mathrm{km})$, square meter $\left(\mathrm{m}^{2}\right)$ hectare (ha)

temperature, degrees Fahrenheit $(\circ F)=1.8(\circ C)+32$

\section{By}

$$
0.3937
$$

3.281

0.6215

10.76

2.471

To obtain inch-pound units

inch (in)

foot $(\mathrm{ft})$

mile (mi) square foot $\left(\mathrm{ft}^{2}\right)$ acre

temperature, degrees Kelvin $(\mathrm{oK})=\mathrm{OC}+273$

The use of trade names in this report is for identification purposes only and does not constitute endorsement by the U.S. Geological Survey. 


\title{
GEOLOGIC DATA COLLECTED AND ANALYTICAL PROCEDURES USED \\ DURING A GEOCHEMICAL INVESTIGATION OF THE UNSATURATED ZONE, RADIOACTIVE WASTE MANAGEMENT COMPLEX, IDAHO NATIONAL ENGINEERING LABORATORY, IDAHO
}

\author{
by \\ Craig T. Rightmire, formerly U.S. Geological Survey \\ and \\ Barney D. Lewis, U.S. Geological Survey
}

\begin{abstract}
To assess the potential migration of low-level radioactive waste in the shallow subsurface it is necessary to understand the hydrogeologic and geochemical characteristics of the unsaturated zone. For this purpose, this data collection study was completed for the unsaturated zone at the Radioactive Waste Management Complex, Idaho National Engineering Laboratory, on the eastern Snake River Plain in southeastern Idaho. Geologic data were needed for input into a model of potential migration of waste that was buried in pits and trenches at the facility between the early 1950's and the early 1970's. Sample preparation and analytical techniques were required that would provide the needed information on geochemical characteristics of the unsaturated zone. Examination of core and surficial sedimentary samples provided the needed data and analytical procedures were established following an intensive literature search.
\end{abstract}

\section{INTRODUCTION}

The Radioactive Waste Management Complex (RWMC) is located at the Idaho National Engineering Laboratory (INEL) on the eastern Snake River Plain in southeastern Idaho (fig. 1). The INEL is comprised of about $2,300 \mathrm{~km}^{2}$ of semi-arid sagebrush covered terrain on the northwest side of the plain.

The plain is an arcuate topographic depression traversing southern Idaho for a distance of approximately $500 \mathrm{~km}$. It ranges from 50 to $100 \mathrm{~km}$ 


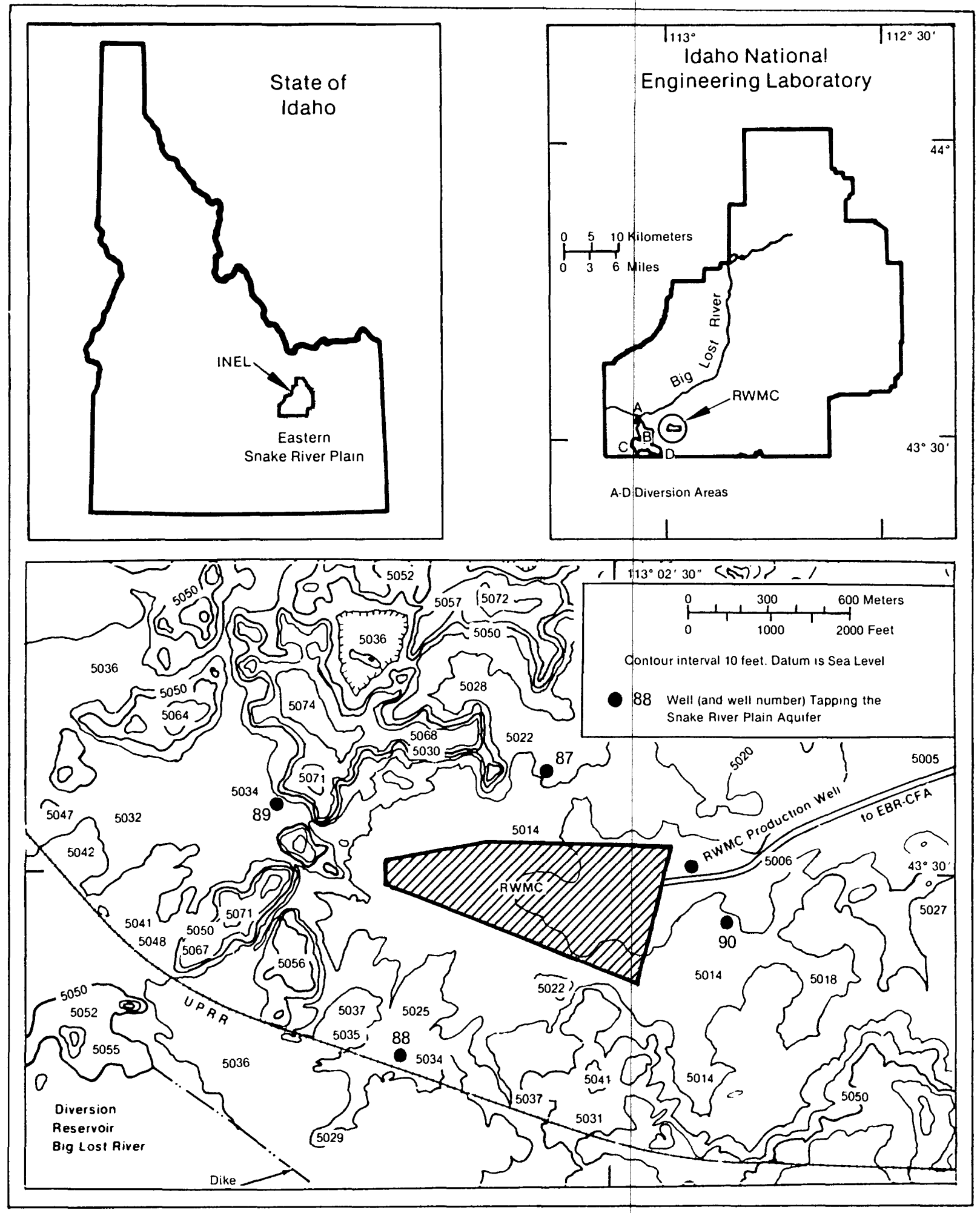

Figure 1.--Location of the INEL and eastern Snake River Plain, and the relationship of the RWMC and adjacent wells to the diversion areas and the Big Lost River (from Rightmire, 1984). 
wide and rises from about $700-\mathrm{m}$ altitude in the west to about $2,000 \mathrm{~m}$ in the east. The eastern Snake River Plain is bounded on the west, north, and east by mountain ranges and high plateaus. Many of the high peaks in these ranges exceed $3,500 \mathrm{~m}$ in altitude. Alluvial valleys draining the mountain ranges to the north and northwest drain onto the plain and the INEL.

The RWMC is in a shallow depression floored by basaltic lava flows and by wind-and water-deposited sediment. It is surrounded by uneven basalt flows of low relief.

Radioactive waste has been buried at the RWMC since 1952. Since 1970, only radioactive wastes with short half-lives have been buried. Transuranic wastes of long half-life have been stored above ground on asphalt pads in retrievable containers.

\section{PURPOSE AND SCOPE}

The overall purpose of this study was to develop a conceptual model of the hydrogeochemical environment of the shallow unsaturated zone of the Snake River Plain, eastern Idaho, and to determine how changes in that environment may influence the mobility and migration of waste radionuclides buried in the subsurface disposal area of the RWMC (fig. 2).

However, data to determine the hydrogeologic and geochemical characteristics of the unsaturated zone had to be collected and analytical procedural techniques had to be established prior to the initiation of analytical and interpretive studies. Visual and optical inspection of cored material collected from 8 wells drilled during a 1976-1977 drilling program, along with subpit sedimentary samples, provided needed data, and an intensive literature search provided the sample preparation and analytical techniques needed to determine pertinent geochemical characteristics.

The objective of this report is to describe cored material and subpit sedimentary samples, and document the sample preparation and analytical 


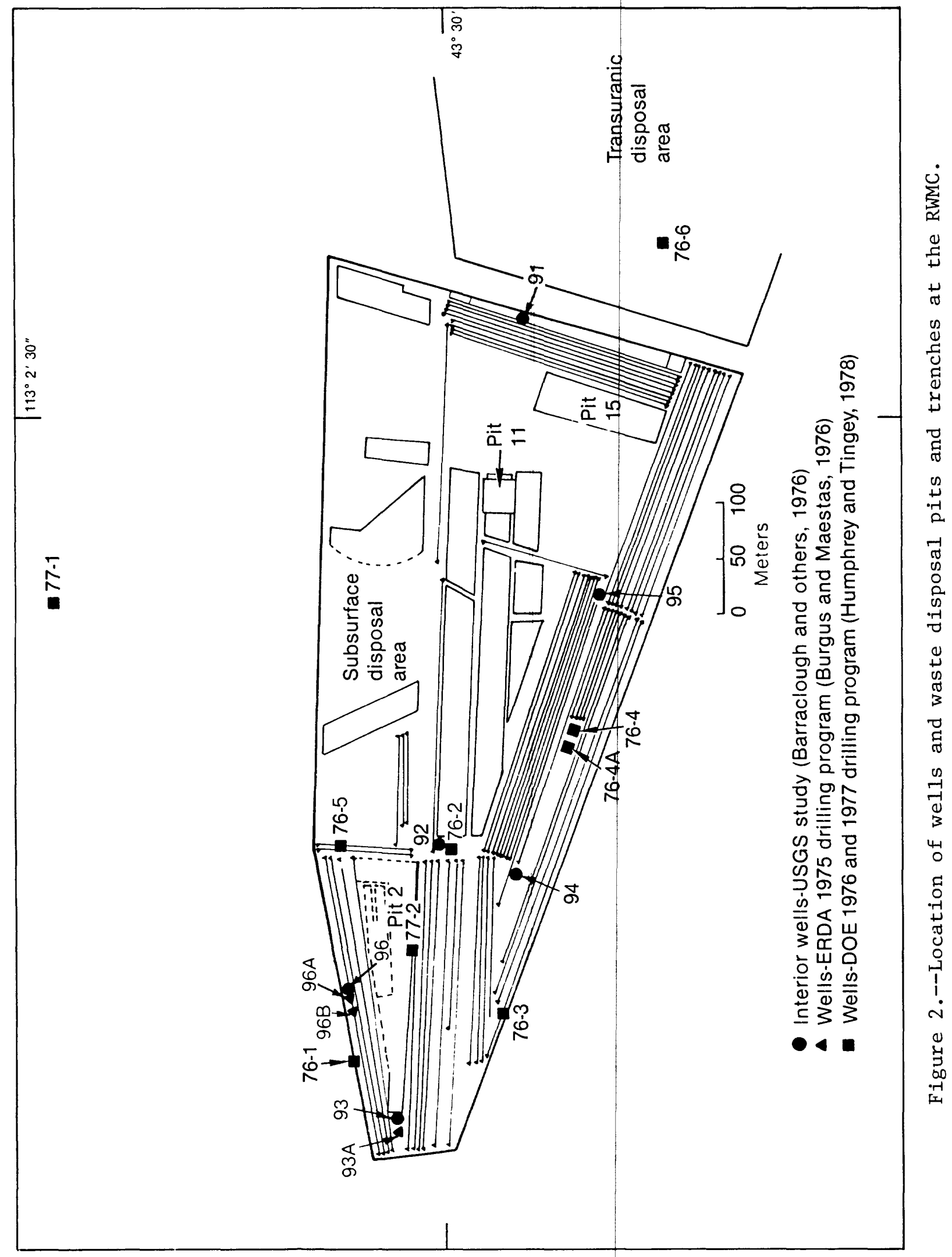


techniques used to characterize the geochemical environment of the unsaturated zone at the RWMC.

\section{PREVIOUS INVESTIGATIONS}

The U.S. Geological Survey has conducted geologic and hydrologic studies on the INEL since the area was selected for a reactor testing area by the U.S. Atomic Energy Commission in 1949. Investigations in the vicinity of the RWMC have been discussed in several reports. These studies included hydrologic and potential radionuclide migration studies at the RWMC carried out by the Geological Survey between 1971 and 1974 (Barraclough, Robertson, and Janzer, 1976), during which 10 wells were drilled; another 3 wells drilled during a study on the radionuclide analyses of collected sediment samples completed during 1975 at the RWMC (Burgus and Maestas, 1976); and a study of radionuclide content of sediment samples from trenches below waste pits (Humphrey and Tingey, 1978) during which 9 additional wells were drilled. Figure 2 shows the locations of selected wells drilled during these various studies at the RWMC and the locations of the disposal trenches and pits.

\section{ACKNOWLEDGMENTS}

These studies were sponsored and funded by the Energy Research and Development Administration, now the Department of Energy and were coordinated through the Idaho Operations office (IDO). Considerable assistance has been obtained from the following IDO personnel: M.M. Williamson, Director, Radiological and Environmental Sciences Laboratory; the staff of the Analytical Chemistry Branch, L.Z. Bodnar, Chief; and E.W. Chew, Chief, Environmental Sciences Branch. 


\section{GENERALIZED GEOLOGY}

The eastern Snake River Plain is underlain by a thick sequence of basaltic rocks and interbedded sedimentary layers, and are all included in the Snake River Group of Quaternary age (Lewis and Goldstein, 1982). The basement rocks are probably composed of older volcanic and sedimentary rocks, in addition to underlying crystalline rocks. The regional geology of the RWMC area is described in detail by Robertson, Schoen, and Barraclough (1974), and Kuntz (1978). Only a brief discussion emphasizing the sedimentary materials and their source areas will be included here.

A sequence of 13 lava flows and flow units have been observed between land surface and $183.9 \mathrm{~m}$ in coreholes drilled at the RWMC. The oldest of these flows is about 500,000 years. The average rate of inundation of the RWMC by a closely spaced group of flows is approximately once every 70,000 years (Kuntz and others, 1980).

The basalt flows are commonly interbedded with and overlain by alluvial and eolian sediments deposited on the eastern Snake River Plain. These sedimentary deposits are composed largely of fine sand, silt, and clay. In present and abandoned stream channels and areas affected by flooding, a significant amount of limestone, quartzite, and basalt pebbles are found.

Alluvial sedimentary deposits were accumulated in depressions on or adjacent to basalt flows during times of high runoff. Lava flows in the past have dammed stream channels causing small lakes to form in which much of the finer sediment is deposited.

Three interflow sedimentary beds have been identified at the RWMC and will be called in this report the $9-\mathrm{m}$, the $34-\mathrm{m}$, and the $73-\mathrm{m}$ beds. The $73-\mathrm{m}$.bed was observed in all wells drilled within the RWMC. Burgus and Maestas (1976) report a bed at about $9-\mathrm{m}$ in wells $96 \mathrm{~A}$ and $96 \mathrm{~B}$ in addition to the $34-\mathrm{m}$ and $73-\mathrm{m}$ beds. The tops, bottoms, and thicknesses of the interflow beds are given in table 1. 


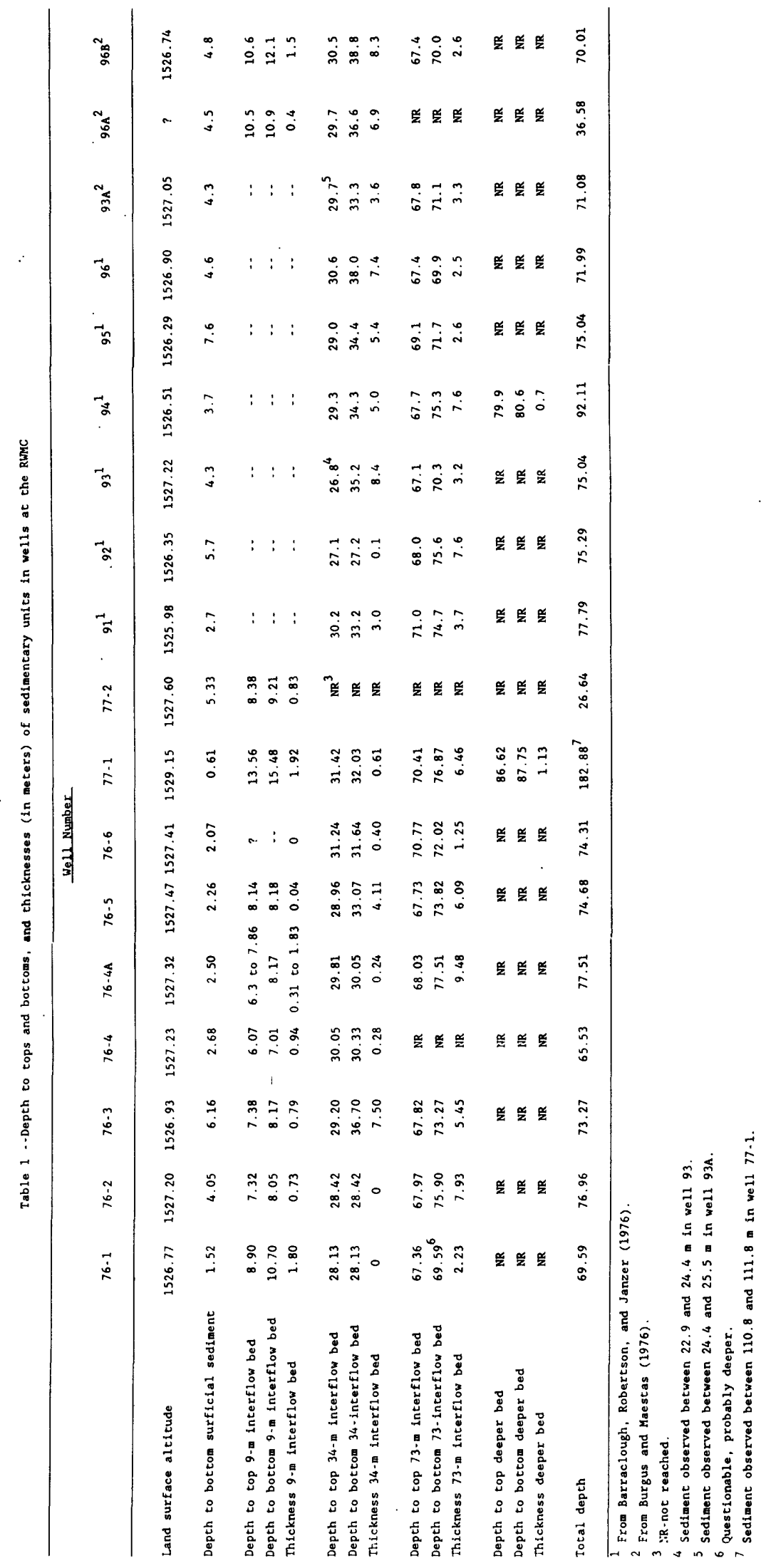


CORE SAMPLE DESCRIPTIONS

Core samples were collected from eight wells for mineralogic and stable isotope analyses. Core material from all three sedimentary interbeds and fracture filling material were submitted for seyeral different analytical procedures. The following section contains the core sample descriptions. 
WELL $76-1$

$76-1-14$

$8 \cdot 90-9 \cdot 54 \mathrm{~m}$

$76-1-15$

$10.70 \mathrm{~m}$

76-1-1

23-27 m

76-1-1(a) Coarse - sample of darker material for x-ray analysissilt. 10YR $7 / 3$.

$76-1-1(b)$

$76-1-1(c)$

$76-1-2$

$27.74-27.83 \mathrm{~m}$ interbed.

Saturated with water, the outside of the core tube is dripping water inside the plastic bag. Perched

Portions of 76-1-1: showing coarser dark material in center of fracture filling and lighter finer material along edges of fracture indicates two phase of fracture filling.

Fine - sample of light pale orange (10 YR 8/2) clay material adjacent to basalt fracture surface.

Very coarse - moderately yellow-brown (10 YR 6/4)

fine quartz sand rich in clay, rich in heavy minerals, mica present, looks oriented.

The contact between clay and basalt appears to be a weathering contact. Where spall clay off wall, takes some of dark minerals from basalt with it. None of the dark minerals are found in clay other than right next to contact.

Flow contact - probably comparable to 34-m interbed. Light-tan clay with some reddish segments - iron
Bright red iron stained silty clay (5 YR 4/6) to 9-m water zone! Yellow orange silty clay (10 YR 5/6). stained? Few anhedral white mineral crystals in clay material similar in appearance to material in vesicles.

White mineral is not carbonate. Evidence of fairly significant weathering - i.e., iron stain in some of basalt and adjacent to some of white precipitate.

Precipitate looks like flowstone.

Precipitate appears to have formed both before and after emplacement of clay.

1. Some vesicles on top surface of lower (red) flow are filled with precipitate, with depressions in precipitate filled with clay.

2. Some clay coating have small white crystals on them (see sample - "bottom upper flow"). 
$76-1-2(a)$

$76-1-2(b)$

$76-1-2(c)$

$76-1-3$

$27.9-28.13 \mathrm{~m}$

$76-1-3(a)$

$76-1-3(b)$
On surface some precipitate lined vesicles partially filled with iron stained fine sand. Almost no sand in evidence in interbed proper.

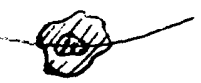
$\because$ Red iron stained sand. "/W White precipitate.

Al1 precipitate present in lower (red) basalt; none apparent in upper clay (gray) basalt.

Material on top of lower flow.

Interbed (?) filling clay-bottom flow.

Mineralization in vesicles.

Check red basalt for progressive alteration toward exposed surface. The amount of precipitate suggests it.

White precipitate deposited in vesicles which at some later time was filled with well rounded fine-medium iron stained quartz. Only relatively few of precipitate lined vesicles also contain sand. No sand. No non-precipitate lined vesicles contain any sand.

All white precipitate material is on upper walls of vesicles; where sand is present a coating of clay material is on the bottom of vesicles.

Vesicle filling sand was dug from vesicle on side of core, moderate brown ( 5 YR $4 / 4$ ).

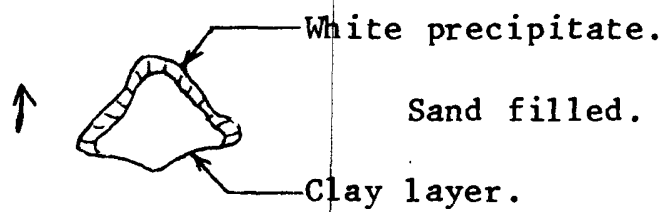

The vesicle was at least $1 \mathrm{~cm}$ deep, 1 ikely connected with diagonal fracture approximately $1.5 \mathrm{~cm}$ below.

Some precipitate lined vesicles adjacent to fracture also contain iron stained sand.

Precipitate in some of vesicles is globular but both globular material and flowstone like material exhibit dessication cracks. These cracks may be post-coring drying. 
Upper surface of horizontal diagonal fracture coated with white precipitate up to $1 \mathrm{~cm}$ thick.

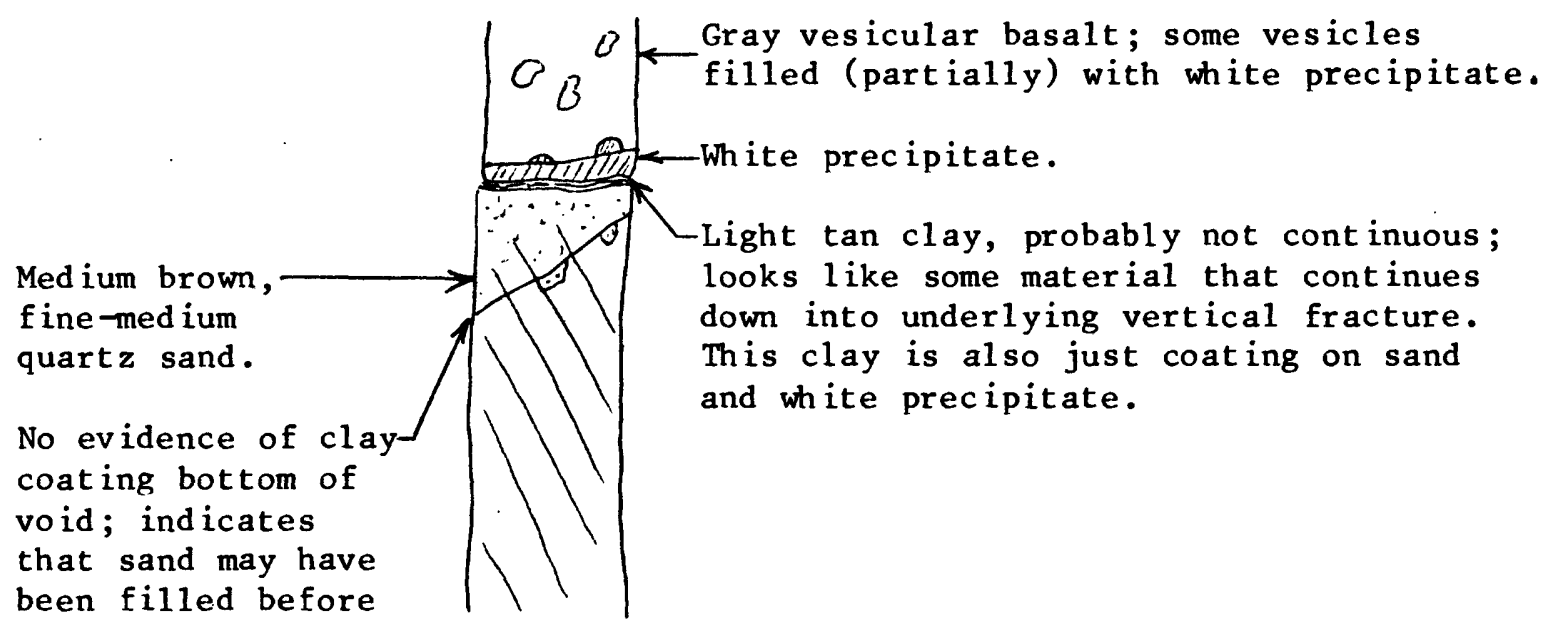

clay.

$$
\begin{array}{r}
76-1-4(a) \\
4(b) \\
4(c)
\end{array}
$$

$76-1-4 \mathrm{~A}$

$28.22-28.56 \mathrm{~m}$

$76-1-5$

$28.56 \mathrm{~m}$
Sand in fracture, 1 ight gray-brown ( 5 Y 6/1). Clay coat ing Clay (overlying), sand in horizontal fracture, yellow gray ( 5 Y 8/1). White precipitate on bottom upper flow. Ion fracture I in both basalt $\checkmark$ and sand.
Clay coating on fracture in basalt beneath sand filled void continues up through sand filling void.

Grayish orange (10 YR 7.5/3) clay from vertical fracture.

1. Sedimented out of moving water, or

2. Were rearranged after formation.

Structures look like drip features on slight overhangs.

Evidence that some of vesicles covered with clay (in vertical fractures) contains sand. Remove some clean clay which has filled a portion of the vesicle. The clay that was in the vesicle has some rounded quartz sand grains stuck to it.

Similar sedimentary-precipitate sequence to that at 76-1-4;

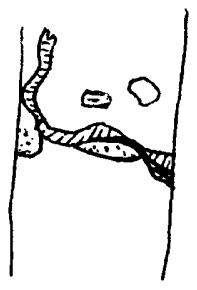

/III White precipitate.

$\cong$ Light tan clay.

$\therefore \quad$ Iron stained quartz sand. 


$$
\begin{array}{r}
76-1-5(\mathrm{a}) \\
76-1-5(\mathrm{~b}) \\
76-1-5(\mathrm{c}) \\
76-1-6 \\
28.56-29.02 \mathrm{~m} \\
76-1-6(\mathrm{a})
\end{array}
$$$$
76-1-6(b)
$$$$
76-1-6(c)
$$

$76-1-6(d)$

No samples

29.47-30.94 m
Samples of:

1. Sand-red brown, iron-stained quartz.

2. Clay - 1ight-tan, similar to overlying fracture filling material. Probably insufficient sample to analyse.

3. White precipitate up to $1 \mathrm{~cm}$ thick, no apparent layering.

Sand-iron stained, light brown ( 5 YR 6/4). Clay-very pale orange (10 YR 8/2). White precipitate.

Vertical fracture clay to absent surface linings, light tan; medium brown fine sand (10 YR 5.2)

filling similar to horizontal fracture filling. $28.56 \mathrm{~m}$ (top of piece of core).

Few thin carbonate (?) stringers, light tan-white $\mathrm{CaCO}_{3}(?)$.

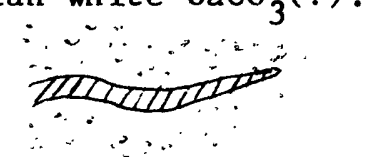

Shows layering in dark yellow-brown sand (10 YR 4/2) in horizontal fracture at top of core piece. Vesicles in this piece of core contain white precipitate.

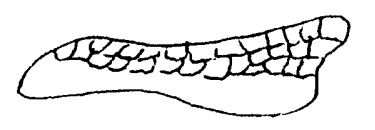

Many of the vesicles cut by fractures were filled first with white precipitate as stalactitic growths and subsequently filled with sand.

The bottom of most of the sand filled vesicles appear to be lined with a thin coating of light-tan clay.

A fracture at the base of the core section (29.05$29.11 \mathrm{~m}$ ) contains only clay, no sand. Evidence of geopetal fabric partially clay filled vesicles. Light-tan clay (10 YR 8/2) overlying medium-brown silt.

Very clean series of vertical to diagonal fractures, some evidence of clays transported by water; few drip structures, very sma11, insufficient quantity to sample. 


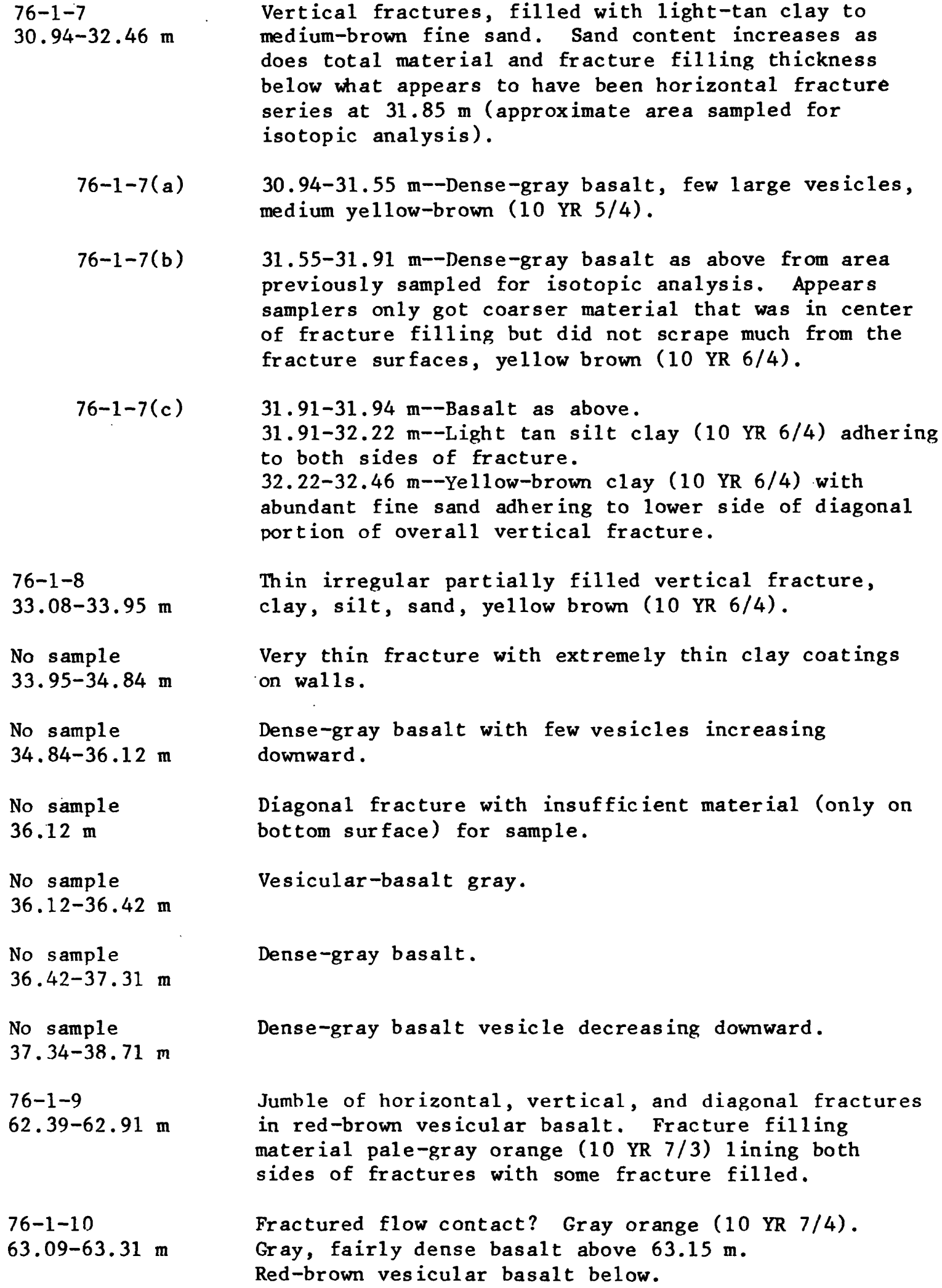

Thin irregular partially filled vertical fracture, clay, silt, sand, ye1low brown (10 YR 6/4).

Very thin fracture with extremely thin clay coatings on walls.

Dense-gray basalt with few vesicles increasing downward.

Diagonal fracture with insufficient material (only on bottom surface) for sample.

Vesicular-basalt gray.

Dense-gray basalt.

Dense-gray basalt vesicle decreasing downward.

Jumble of horizontal, vertical, and diagonal fractures in red-brown vesicular basalt. Fracture filling material pale-gray orange (10 YR 7/3) 1 ining both sides of fractures with some fracture filled.

Fractured flow contact? Gray orange (10 YR 7/4). Gray, fairly dense basalt above $63.15 \mathrm{~m}$. Red-brown vesicular basalt below. 
76-1-11

$63.46 \mathrm{~m}$

76-1-12

64. 74-64.92 m

76-1-13

66.14-66.20 m

76-1-16

$67.64 \mathrm{~m}$

76-1-17

$68.34 \mathrm{~m}$

76-1-18

$69.01 \mathrm{~m}$

76-1-19

$69.43 \mathrm{~m}$

76-1-20

$69.43-69.59 \mathrm{~m}$

TD
Diagonal-fracture filling, very pale-orange clay (10 YR 8/2).

Clay fracture-filling material in diagonal, vertical, and horizontal fracture; but not very much material. Very pale orange (10 YR $8 / 2)$.

Layered, pale-gray-orange clay (10 YR 7/3) material filling fracture in dense-gray basalt; up to $2 \mathrm{~cm}$ thick-red stain underlying much of clay material on basalt surface.

Top was sampled for isotopic analysis, but results not recorded. Red-brown silty clay (10 YR 4/4).

Bottom of above core, moderately yellow-brown clay (10 YR 5/4), dry but not powdery.

Bottom of core, dark-yellow brown (10 YR 4/4) clay, slightly plastic.

Bottom of core (moldy) yellow brown (10 YR 4/4), slightly mottled clay, less plastic than above.

Mixed-up core, yellow-brown (10 YR 7/2) hard-dry clay. 
$76-2-1$

$4.88 \mathrm{~m}$

$76-2-1(a)$

$76-2-2$

$5.12 \mathrm{~m}$

$76-2-3$

$7.32 \mathrm{~m}$

9-m interbed?

76-2-3(a)

$76-2-3(b)$

$76-2-3(c)$

$76-2-4$

$7.71-8.05 \mathrm{~m}$

$76-2-4(a)$

$76-2-4(b)$

$76-2-5$

$9.42 \mathrm{~m}$
Diagonal fracture in gray-vesicular basalt filled with 1 ight-tan $(5 \mathrm{Y} 7 / 2)$ clay previously sampled for isotopic analyses, so not much material left. Small quantity of wite-chemical precipitate on upper side of horizontal fracture at $4.83 \mathrm{~m}$.

White precipitate in large vesicle above diagonal fracture.

White precipitate on bottom piece of core, looking up toward top of vesicle.

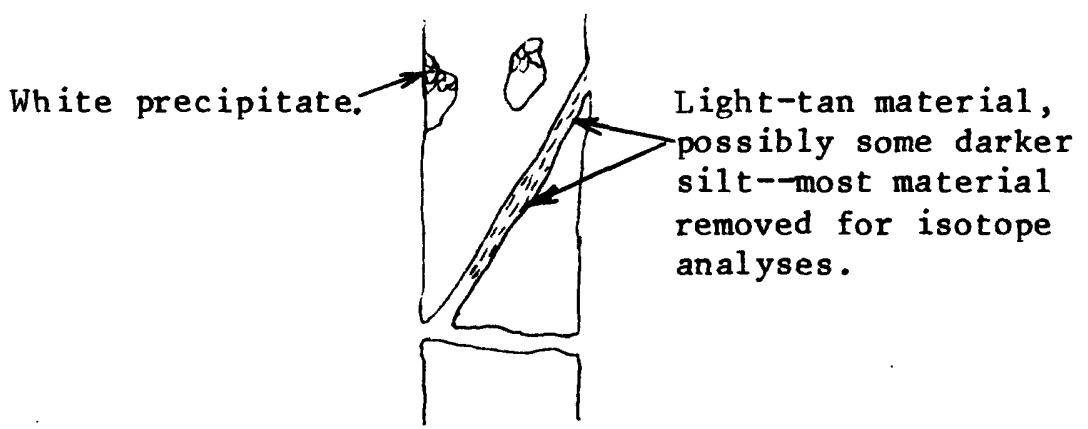

Horizontal fracture in very slightly vesiculargray basalt filled with light-tan clay ( $5 \mathrm{Y} 7 / 2$ ).

Interflow contact--much material removed for isotopic analysis. Red-brown silt clay as thin interbed between vesicular basalts.

Pale-yellow-brown clay (10 YR 6/3)--bottom of overlying flow.

Light tan and orange silt/clay (10 YR 5/4) in the light-tan clay, possibly moved down after overlying flow baked surface. Since isotopic-analyses sample destroyed, relationships hard to determine.

Yellow-brown silty clay (10 YR 5/5) on bottom of diagonal fracture is disrupted contact.

Dark-brown clay in horizontal to diagonal fracture.

Dark-brown material (10 YR 3/2) from top surface.

Brown clay (10 YR 5/2) from bottom surface.

White precipitate in cindery, oxidized, red-brown base of flow; at least part $\mathrm{CaCO}_{3}$, effervesces in dilute $\mathrm{HC} 1$. 
$76-2-5(a)$

$9.11 \mathrm{~m}$

$76-2-6$

$11.80-12.01 \mathrm{~m}$

76-2-7

$12.19 \mathrm{~m}$

76-2-8

$14.87 \mathrm{~m}$

$14.60 \mathrm{~m}$

$76-2-9$

$17.37-17.65 \mathrm{~m}$

$76-2-10$

$18.29 \mathrm{~m}$

$76-2-11$

$18.90 \mathrm{~m}$

$76-2-12$

$22.37-23.83 \mathrm{~m}$
Carbonate flowstone-stalactites; top of vug, showing inverted mushroom structure.
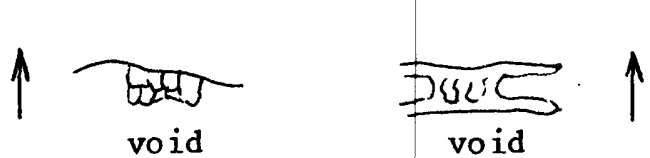

Voids, large vesicles, and diagonal fractures in medium-vesicular basalt. Insufficient sediment to sample top fracture at $11.49 \mathrm{~m}$. Good coating of light-tan clay (5 YR 6/2) on bottom of diagonal fracture at $12.01 \mathrm{~m}$.

As above, diagonal fractures filled with light-tan clay (5 YR 6/2).

Diagonal fracture in slightly vesicular basalt (above) to dense (below) gray-basalt fracture filling-thin yellow-gray clay ( $5 \mathrm{Y} 7 / 2$ ).

Basalt dust caving clay drape--1ike structure on bottom of void.

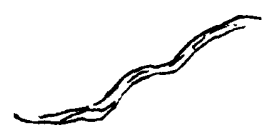

Clay looks like it slumped over lower material when wet and then dried. Surface desiccation crack.

Diagonal and vertical fractures in dense-gray basalt filled with yellow-gray clay ( 5 Y $7 / 2)$.

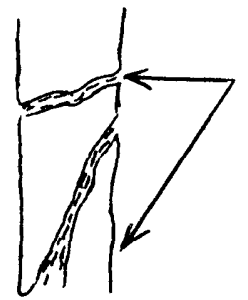

Fracture filling material continued downward to $17.83 \mathrm{~m}$. Same fractures, same material; fractures increase downward into vesicular basalt (bottom of flow?).

Flow contact (?) filled with clay; light-olive gray ( 5 Y 6/2). Sampled for isotopic analys is so appearance and structure destroyed. Some red-brown-oxidized basalt adjacent to fracture (void).

Diagonal fracture in vesicular basalt filled with yel low-gray clay $(5 \mathrm{Y} 7 / 2)$. Vertical fractures continue downward $0.61 \mathrm{~m}$ with some but not abundant clay lining.

Series of vertical, diagonal, and horizontal fractures partly filled to filled with light-yellow gray fine-silt clay ( 5 Y $7 / 2$ ). 
$22.95 \mathrm{~m}$

76-2-13

24. $41-24.60 \mathrm{~m}$

76-2-14

$24.99 \mathrm{~m}$

76-2-15

$28.58 \mathrm{~m}$
Some laminated clay with very fine sand, medium brown, overlying (?) two sequences of infilling.

Light yellow-gray clay ( 5 Y 7/3) filling large vesicles in coarsely vesicular dark-gray basalt.

Flow contact? Dark-gray vesicular basalt above, light-gray dense basalt below void filled with sediment. Yellow-gray clay silt ( 5 Y $7 / 3$ ).

Interflow contact; on bas is of weathering and appearance of underlying flow. Likely comparable to $34-m$ interbed.

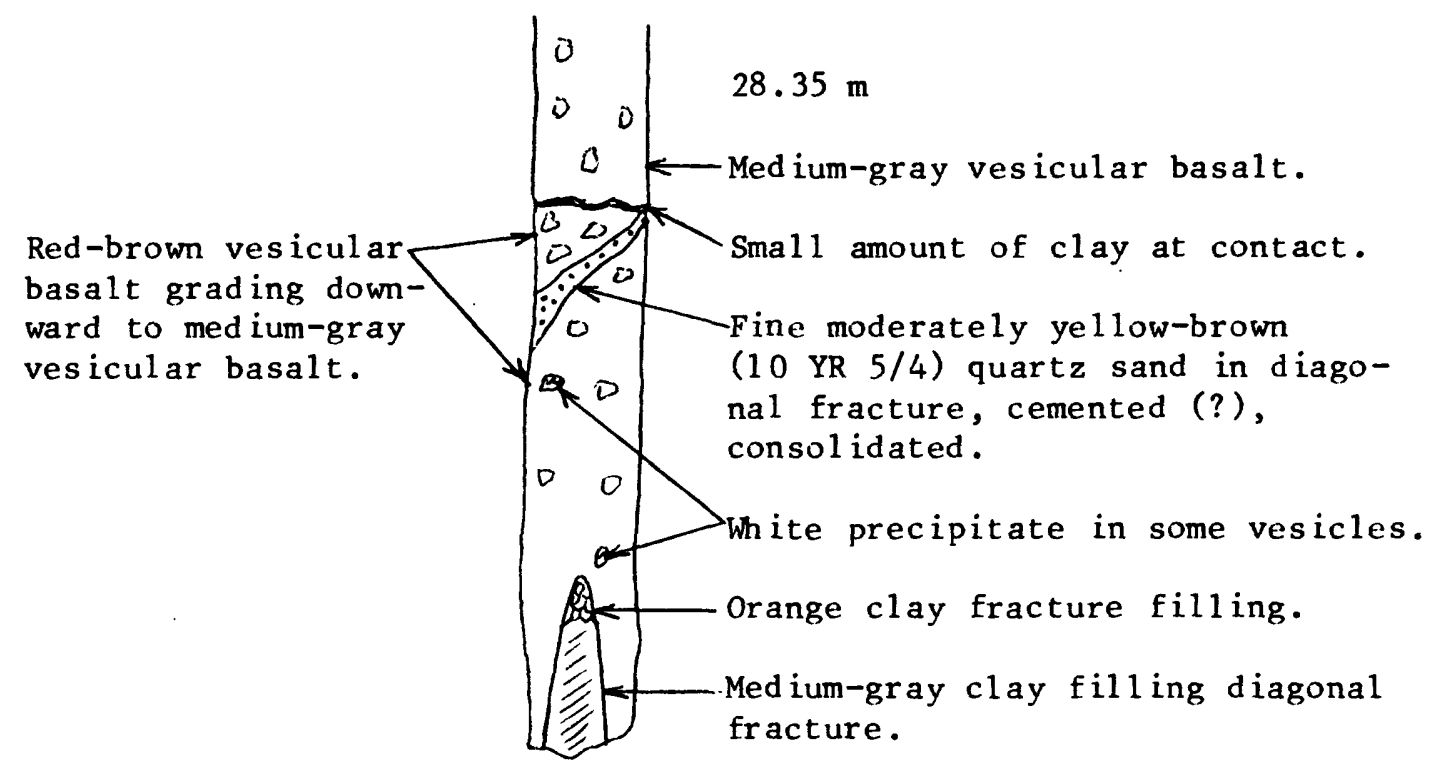

No carbonate as cement in sand or precipitate in vesicles. $76-2-15(a)$ White precipitate in vesicles at $28.42 \mathrm{~m}$.

See lower portion of sketch above.

Diagonal fracture and associated vesicles filled with $\mathrm{CaCO}_{3}$ and clay minerals. Gray-orange silty-fine sand ${ }^{3}(10$ YR $7 / 4)$ in horizontal fracture, also $\mathrm{CaCO}_{3}$ cemented.

Material in vertical fracture extremely tightly cemented. Either baked or thoroughly $\mathrm{CaCO}_{3}$ cemented. $\mathrm{High} \mathrm{CaCO}_{3}$ content.

76-2-16(a) Horizontal fracture material, has some appearance of being thin 1 ight-brown gray ( 5 YR $6 / 1$ ) soil zone (?) fibrous. 
76-2-17

30.05-30.48 m

$43.43-46.51 \mathrm{~m}$

$76-2-18$

$44.56 \mathrm{~m}$

76-2-19

$66.84 \mathrm{~m}$

76-2-20

$67.97 \mathrm{~m}$

$76-2-20(a)$

$76-2-20(b)$

$76-2-20(c)$

76-2-21

$68.70 \mathrm{~m}$

$76-2-22$

$69.68 \mathrm{~m}$

$76-2-23$

$70.56 \mathrm{~m}$

76-2-24

$71.69 \mathrm{~m}$

76-2-25

$74.34 \mathrm{~m}$
Diagonal to vertical fractures only partially filled with yellow-gray ( 5 Y 7.5/3) to medium-brown sedimentary material, clay to silt. Clay 1 ining some vesicles--no $\mathrm{CaCO}_{3}$.

White-precipitate 1 ining, some of vesicles overlain by clay.

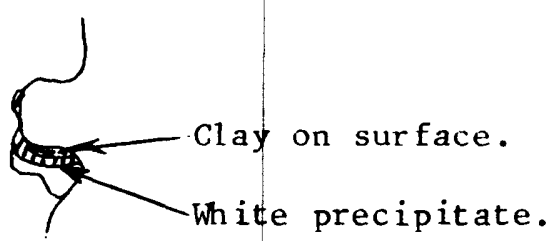

Many large vesicles, adjacent vertical fractures, 1 ined with curled clay.

Rapid transition from dense-gray non-vesicular basalt to reddish-brown fractured-vesicular basalt. The

fractures have white surfaces but do not appear to be coated with any clay material.

Red-brown fractured basalt. Possibly weathered surface.

Horizontal fracture at junction between gray vesicular basalt and dense-gray basalt.

Fracture filled with yellow-gray clay ( 5 Y $7 / 2$ ).

Top of $73-m$ interbed.

Fracture (diagonal) leading down to top of interbed. Interbed has light-tan clay overlying red-brown silt.

Gray-yellow clay (5 Y 8/4) from top interbed.

Red-brown silt (5 YR 5/6).

Pale-orange clay (10 YR 8/2) from diagonal fracture, from approximately 5 to $10 \mathrm{~cm}$ above top of interbed.

Red-brown silt (5 YR 4/4), carbonate filled root tubes. Much carbonate in soil.

Bottom of core.

Dark brown (10 YR 5/4) fine sand, slight carbonate content.

Bottom of core.

Medium-brown fine sand (5 YR 4/5).

Bottom of core.

Medium dark brown fine sandy clay (5 YR 4/4).

Bottom of core.

Moderately yellow-brown plastic clay (10 YR 5/4).

Bottom of core. 
$76-3-1$

$6.95 \mathrm{~m}$

No sample remains.

$7.38-7.56 \mathrm{~m}$

Interbed(?)

$7.38-7.56 \mathrm{~m}$

No sample remains.

Diagonal fracture in dense-gray basalt overlying vesicular portion of flow.

Filled with light-tan clay material.

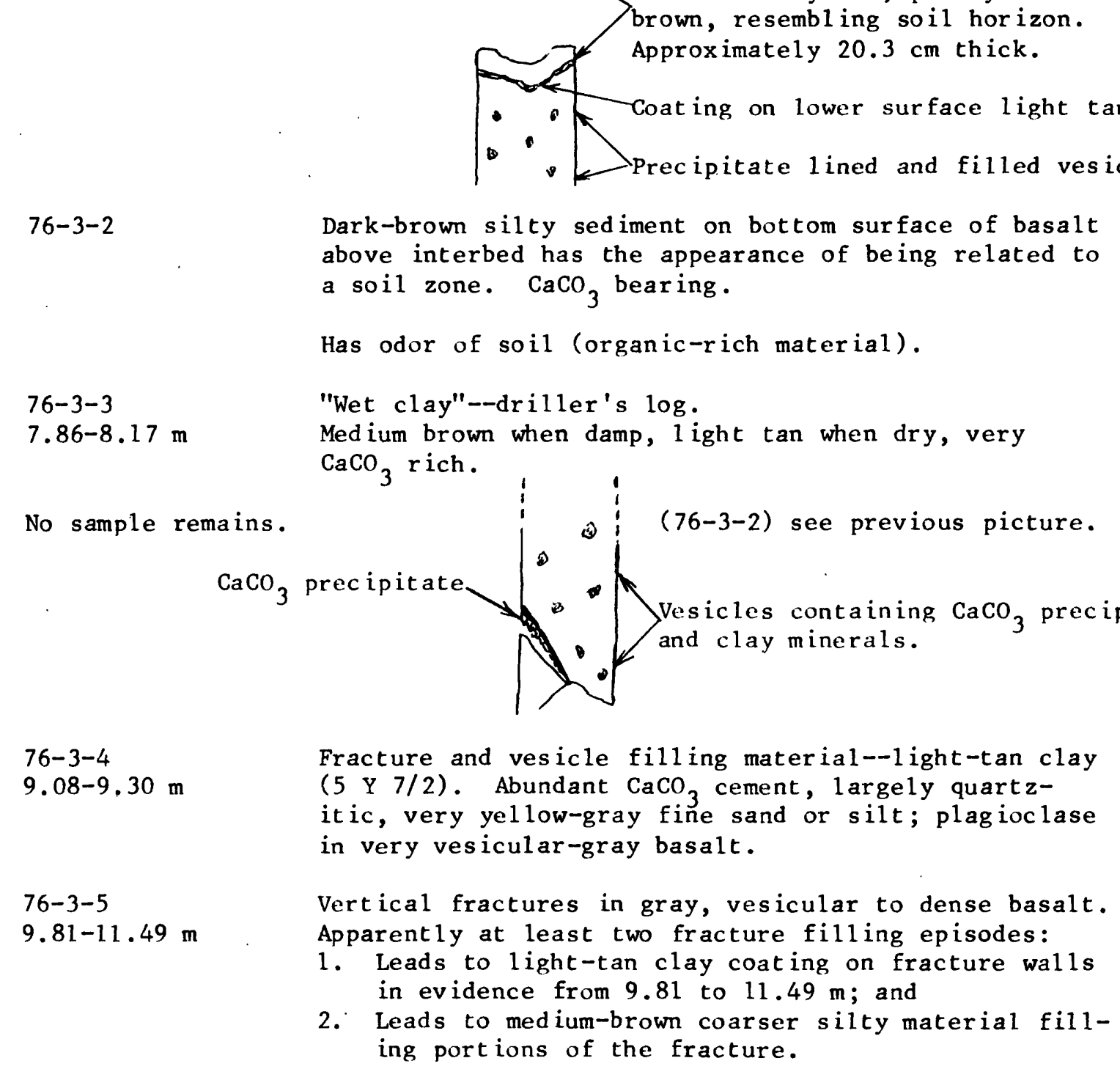

Vertical fractures in gray, vesicular to dense basalt. Apparently at least two fracture filling episodes:

1. Leads to 1 ight-tan clay coating on fracture walls in evidence from 9.81 to $11.49 \mathrm{~m}$; and

2. Leads to medium-brown coarser silty material fil1ing portions of the fracture.

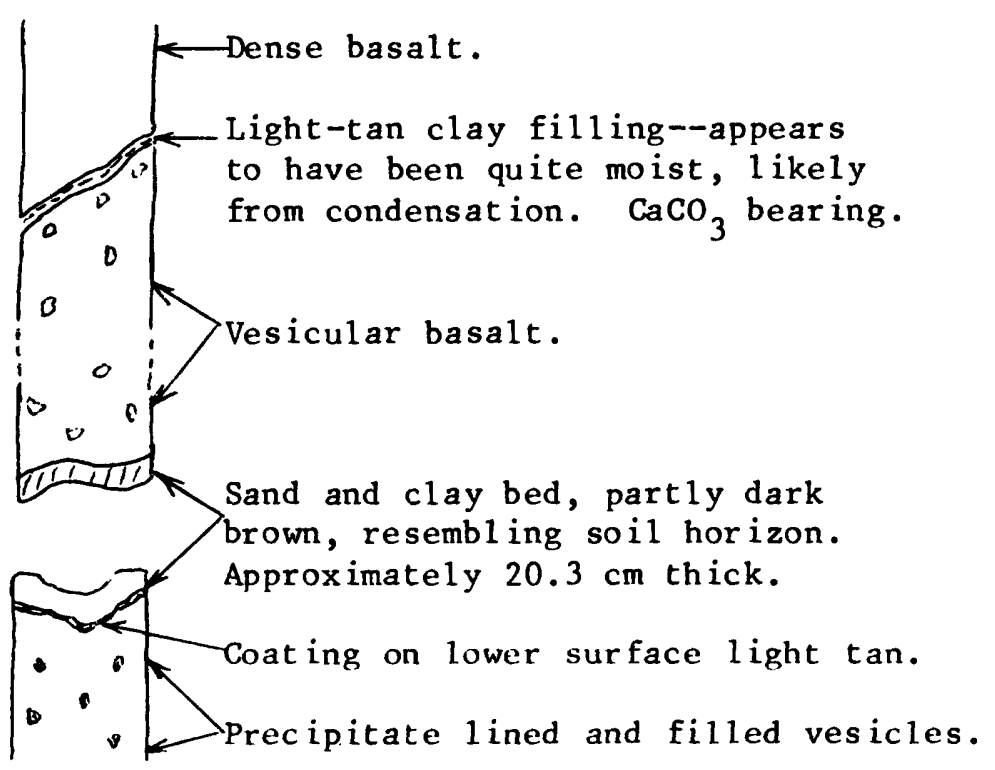


76-3-5 (cont.)

$76-3-5(a)$

$76-3-5$ (b)

$76-3-5(c)$

76-3-6

$11.03-11.34 \mathrm{~m}$

$76-3-7$

$19.84-20.48 \mathrm{~m}$

Only slightly calcareous.

Fracture must have been up to $1 \mathrm{~cm} \pm$ wide by amount of sedimentary material found loose in box between 9.81 and $10.06 \mathrm{~m}$.

Top of fracture series 9.81 to $10.06 \mathrm{~m}$ calcareous (5 Y 7/2).

Middle of fracture series 10.42 to $10.55 \mathrm{~m}$, very slightly calcareous to non-calcareous ( 5 Y 5/2).

Light-tan clay; evidence of either:

1. Root tubes or,

2. Worm burrows through mud deposited from water. Calcareous ( 5 Y 7/2).

Diagonal fracture at vesicular unit in fairly densegray basalt.

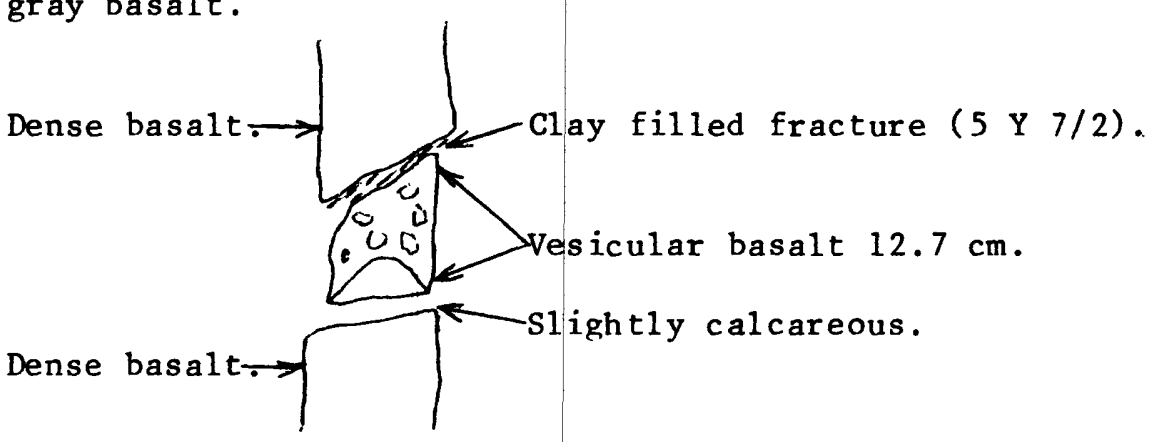

Horizontal fracture at transition from gray-dense basalt to dark-gray vesicular basalt, approximately $0.3 \mathrm{~m}$ above transition to red-brown vesicular basalt (10 YR 5/4).

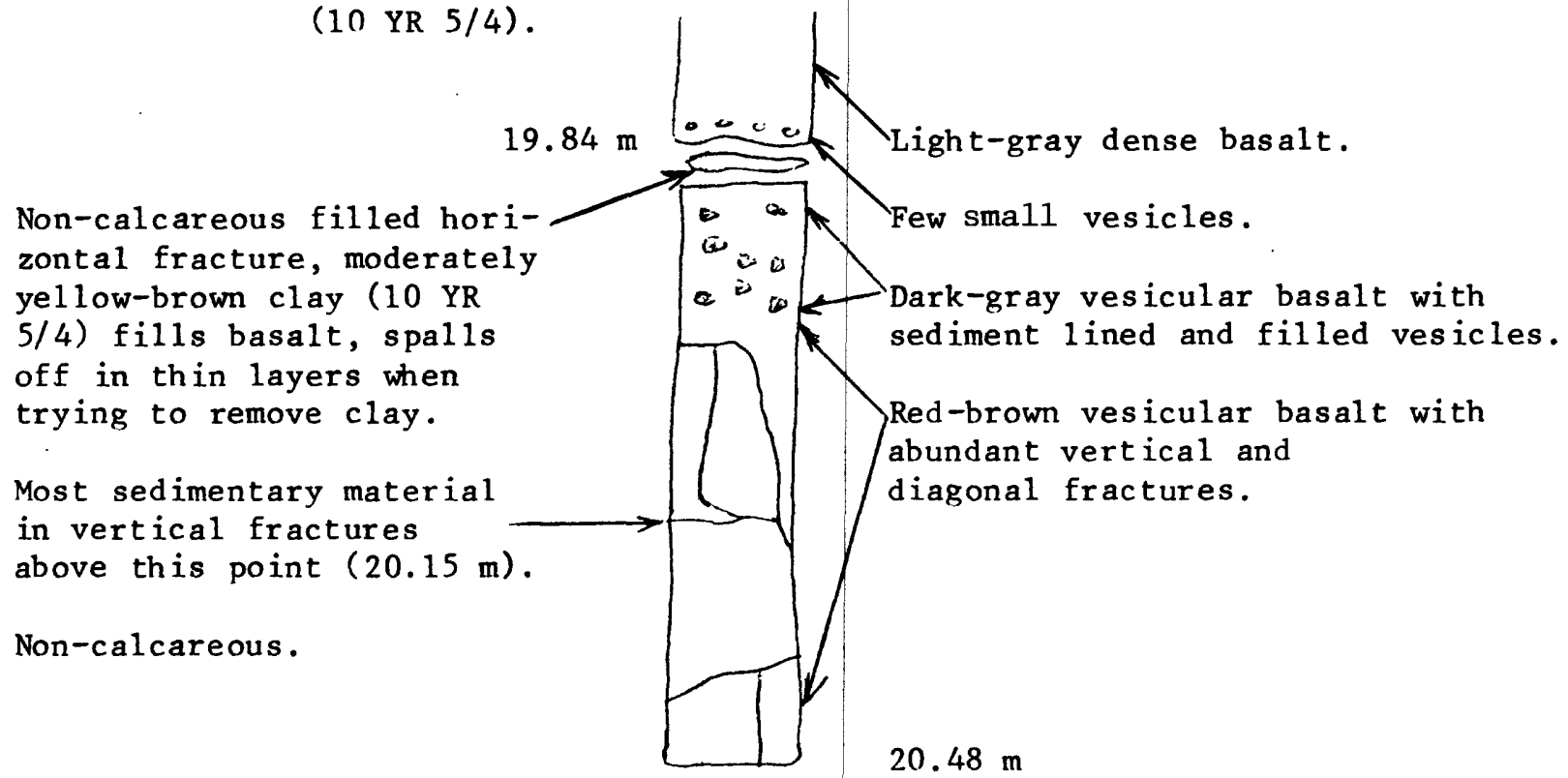


$76-3-8$

$19.99-20.82 \mathrm{~m}$

76-3-9

$22.04-22.68 \mathrm{~m}$

$76-3-10$

$24.78 \mathrm{~m}$

$76-3-11$

$76-3-11$ (a)
Horizontal, vertical, and diagonal fractures in medium-brown vesicular basalt. Horizontal fractures contain significant quantities of sedimentary material, primarily light-tan clay (10 YR 7/4) with some silt. Vertical fractures are lined with light-tan clay only (see above diagram)--primarily from 19.99 to $20.15 \mathrm{~m}$.

22.04-22.34 m--Dense-gray basalt with few vesicles; vertical fracture filled with yellow-gray fine material ( $5 \mathrm{Y} 7 / 2$ ). Clay material holds two pieces of basalt together like cement.

22.34-22.68 m--Identical rock type by fracture, not cemented together.

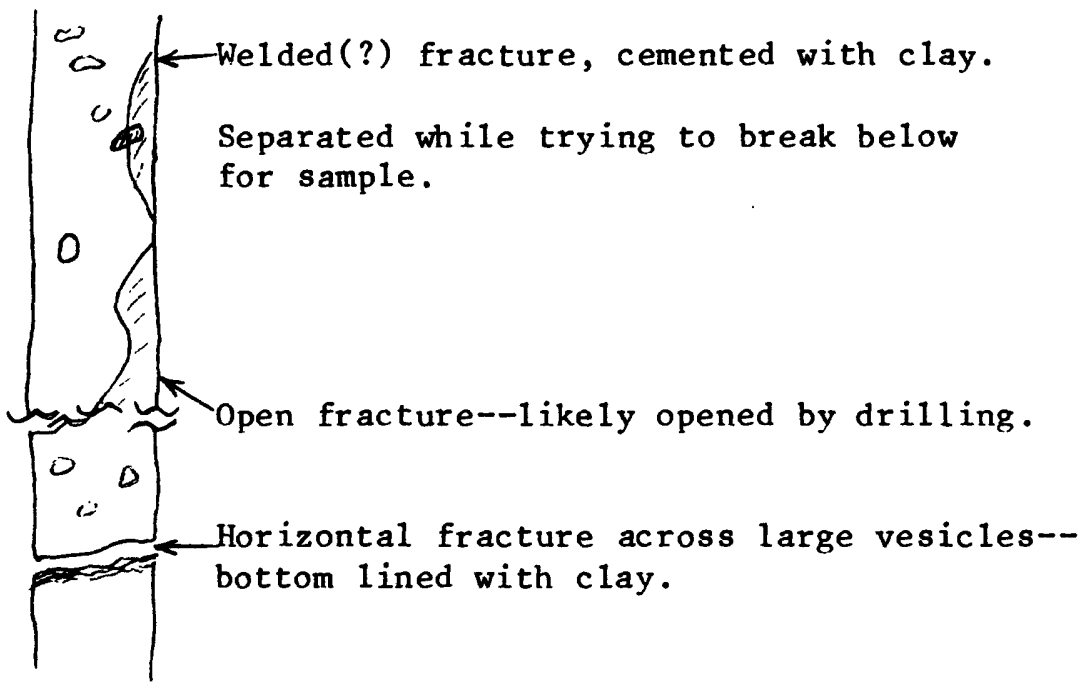

Diagonal fracture in dense-gray basalt filled with yellow gray $(5 Y 7 / 2)$.

Diagonal fracture showing obvious evidence of two episodes of fracture filling.

1. Light-tan clay material on lower fracture wal1; and

2. Medium-brown fine-sand lining fracture proper, approximately 50 percent heavy minerals(?).

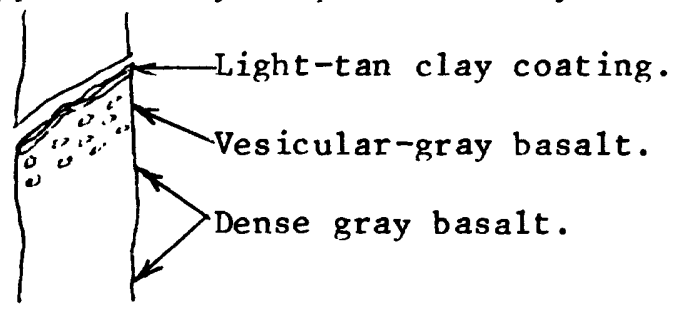

Upper surface material--sand, very fine, fine olive gray ( 5 Y $6 / 2$ ), high percentage heavy minerals; thin to non-existent clay coating on wall but some of the vesicles contain clay. 
76-3-11(b) Lower surface--clay coating, up to 2-mm thick yellow gray $(5 \mathrm{Y} 7 / 2)$. There appears to be sand similar to that overlying the clay, underlying it as well. The clay appears 1 aminated implying sand moved in by major recharge events and clay moved in by a series of minor events between the major events.

$76-3-12$

$27.80-28.80 \mathrm{~m}$
$76-3-13$

$29.11-29.50 \mathrm{~m}$

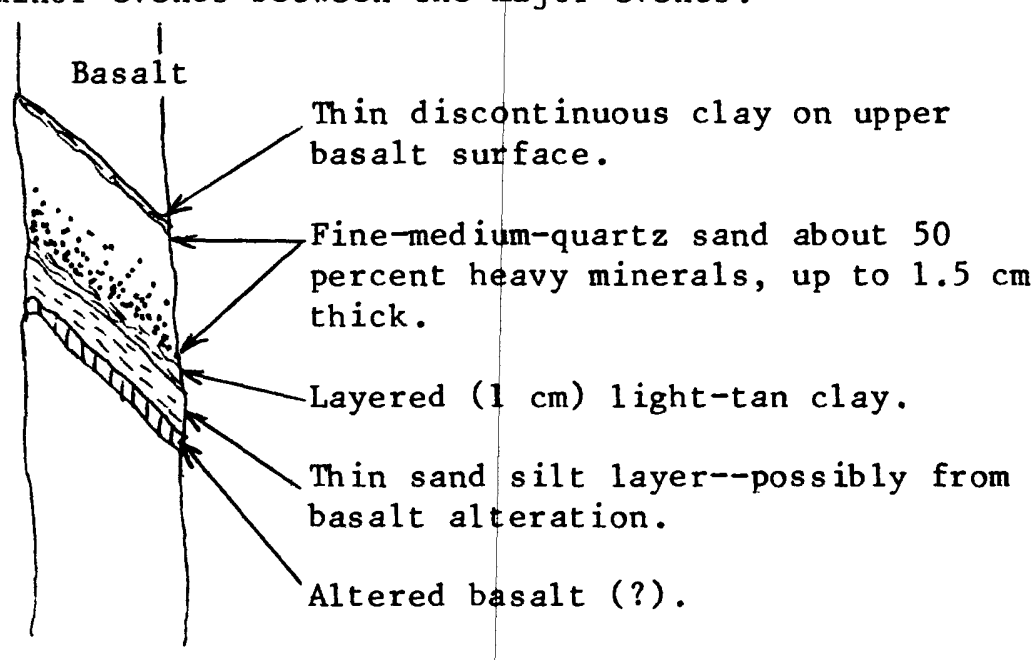

Diagonal fractures from 27.80 to $28.04 \mathrm{~m}$ contain no sedimentary infilling. Below $28.04 \mathrm{~m}$, yellow-gray clay (5 Y 7/2) fills vertical fractures.

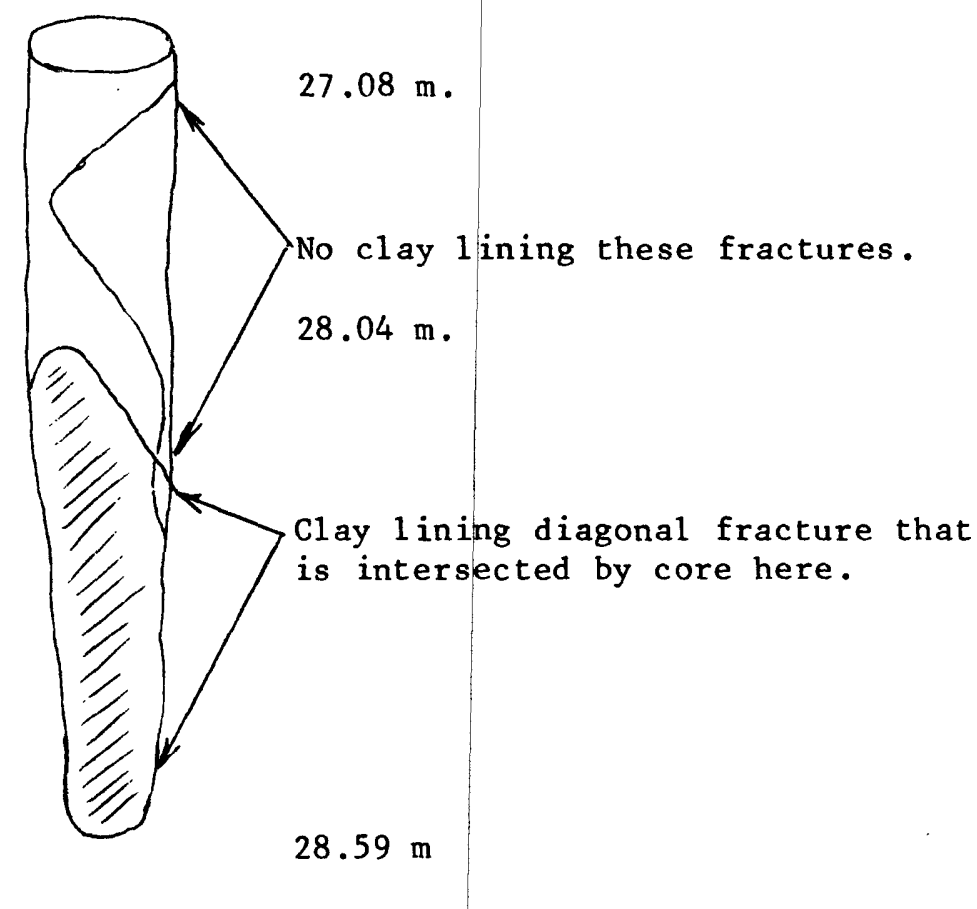

Red-brown to orange sedimentary material within cinder zone immediately over $34-m$ interbed--when taken out of plastic bag, it was saturated with $\mathrm{H}_{2} \mathrm{O}$. 


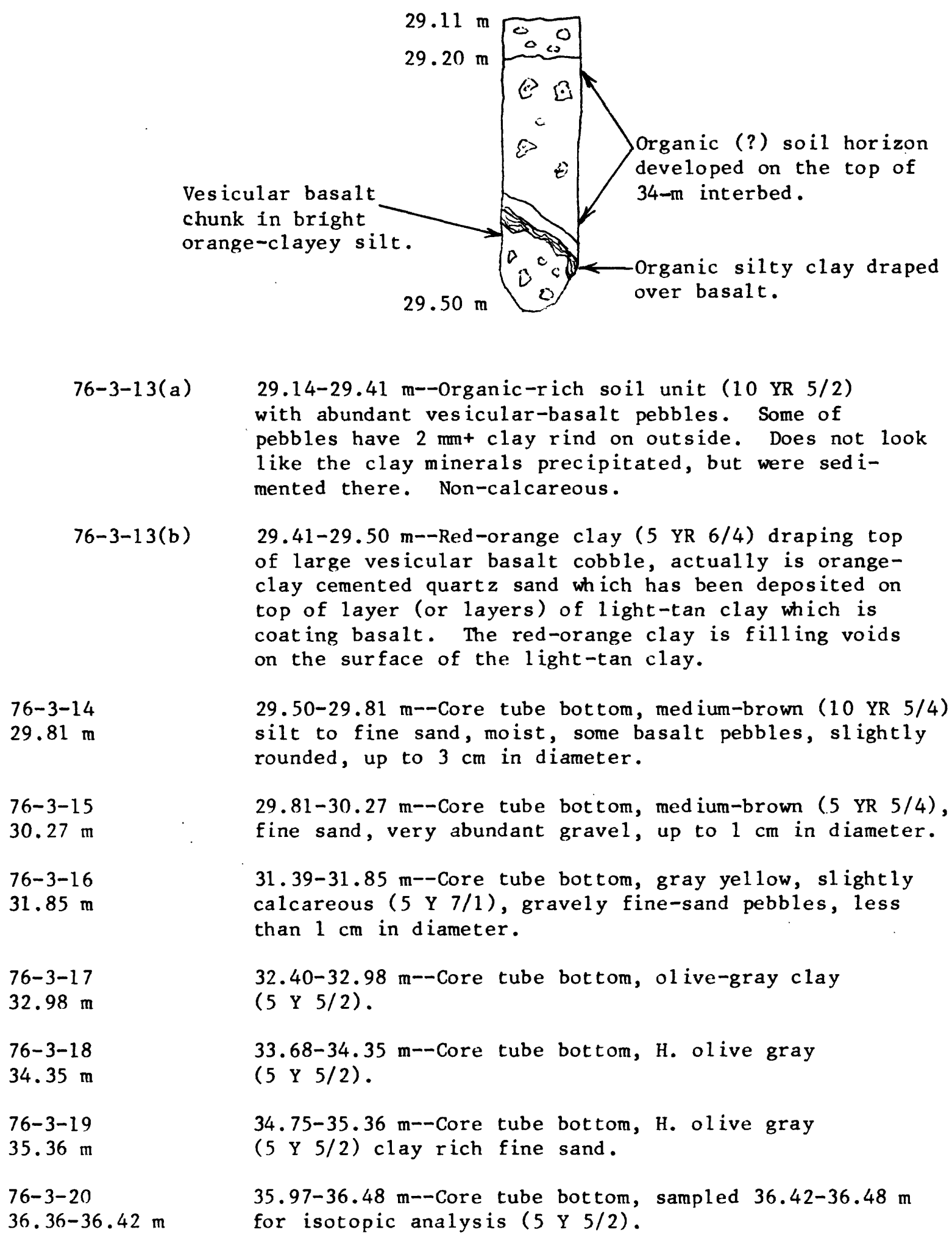


76-3-21

$36.73-36.88 \mathrm{~m}$

$36.70 \mathrm{~m}$

$36.88 \mathrm{~m}$

$37.31 \mathrm{~m}$

76-3-22

$7.92-38.25 \mathrm{~m}$

Vesicular gray basalt, some vesicles partly filled with clay silt.

$38.25 \mathrm{~m}$

$76-3-22(b)$
Vesicular, medium-gray basalt, extremely fractured--all fractures to a depth of $38.25 \mathrm{~m}$ filled with cement; many vesicles adjacent to fractures filled--all material fine sandy silt with abundant clay, moderately yellow-brown (10 YR 5/4).

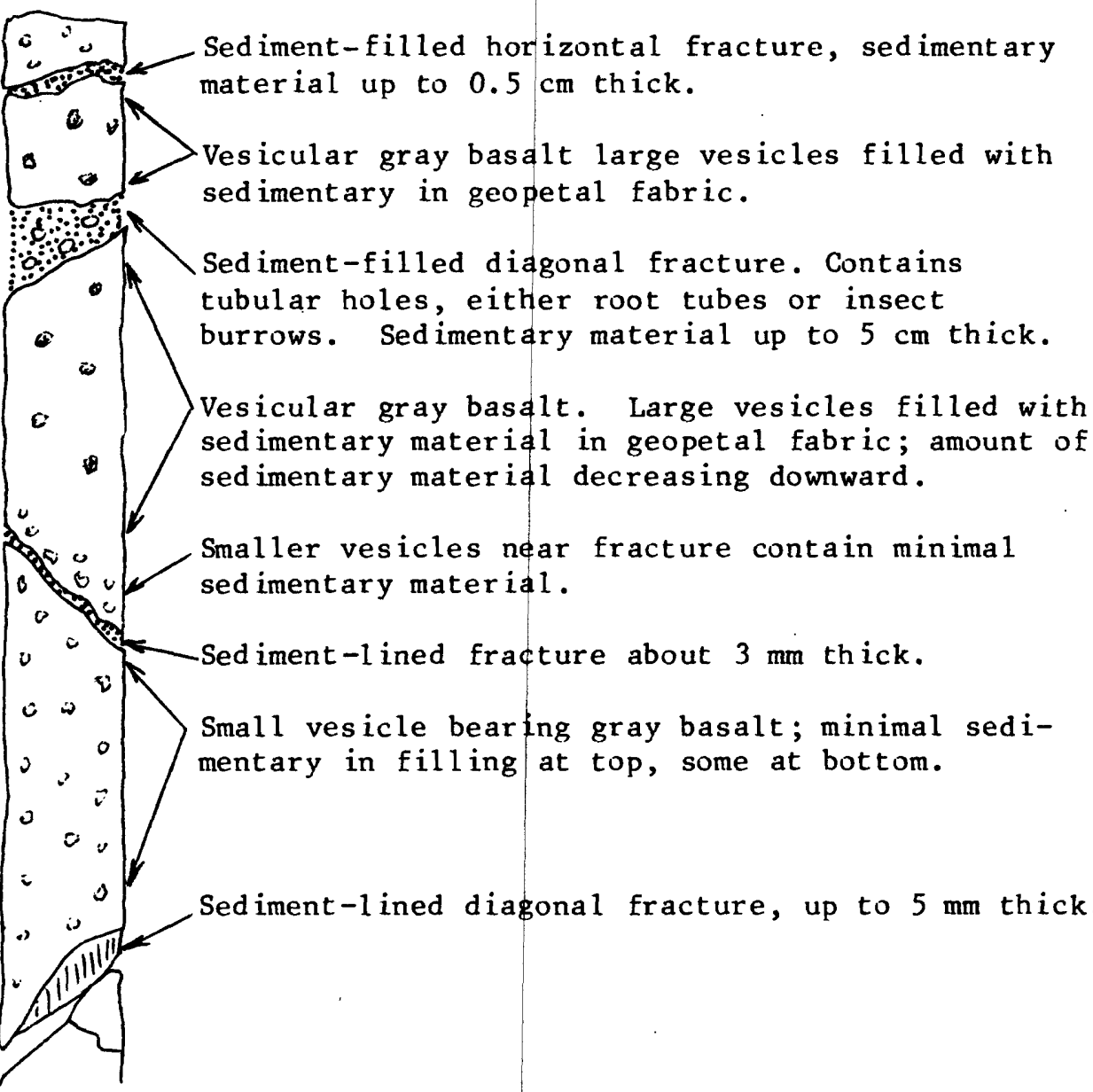

Sediment-filled fractures in medium-gray finelyvesicular basalt, some of vesicles below $37.92 \mathrm{~m}$ partially filled with sedimentary material in geopetal fabric.
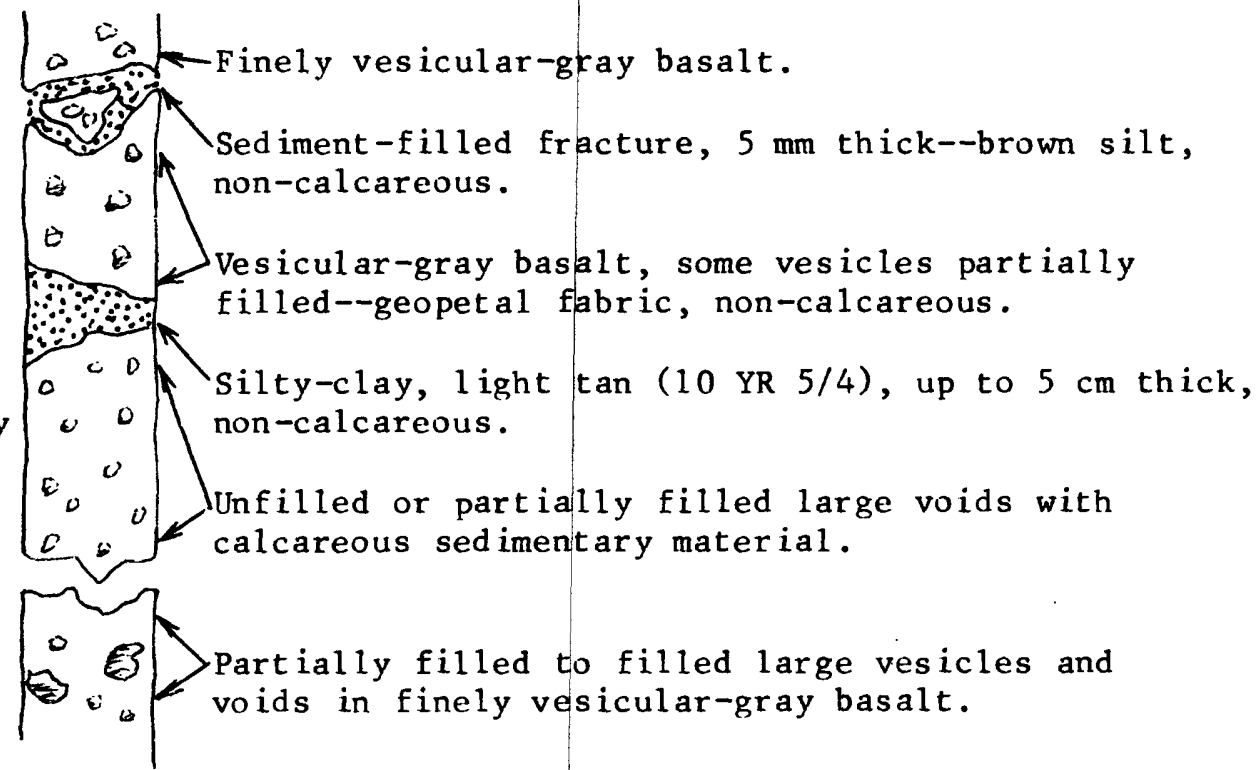

Partially filled to filled large vesicles and voids in finely vesicular-gray basalt. 
$76-3-22(b)$

(cont.)
Fibrous, 1athlike mineral, also mucelaginous coat ing over exposed clay surfaces (10 YR 5/4). Very hard, when broken shows crystal faces on broken surface-appears to have been formed prior to infilling with sand. Likely most $\mathrm{CaCO}_{3}$ present in some of sandy filled vesicles.

Possible that this is cement from some adjacent cemented hole.

Rock bit samples from $39.84-65.53 \mathrm{~m}$.

Dense-gray basa1t at $65.53-67.82 \mathrm{~m}$, clay at $67.82 \mathrm{~m}$ (top of 73-m interbed).

$76-3-23$

$67.82 \mathrm{~m}$

Dense-gray basalt to with in $15.2 \mathrm{~cm}$ of top of $73-\mathrm{m}$ interbed.

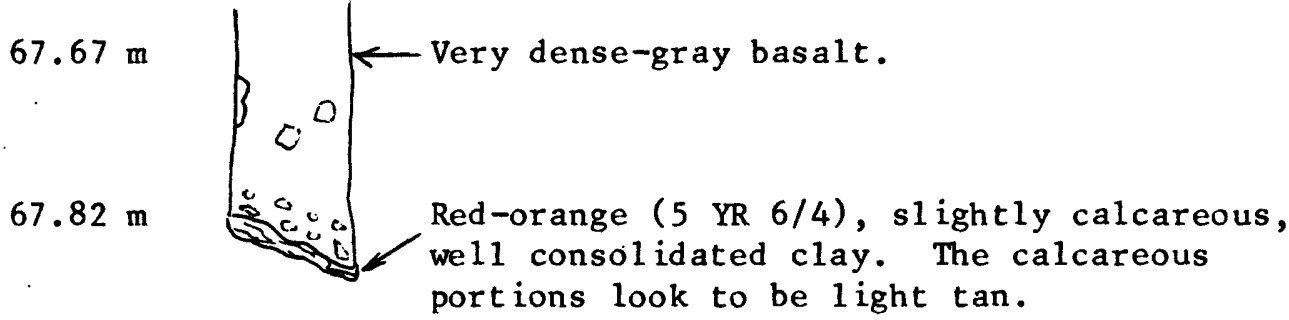

$67.82 \mathrm{~m}$

$76-3-24$

$06.88 \mathrm{~m}$

76-3-25

$70.41 \mathrm{~m}$

$76-3-26$

$71.99 \mathrm{~m}$

$76-3-27$

$73.27 \mathrm{~m}$
Top of "73-m interbed"

Bottom of core 68.58-68.88 m--Red-brown clay (5 YR 6/4), dry, semi-consolidated.

Bottom of core 70.01-70.41 m--yellow-brown clay (10 YR 5/5), slightly calcareous, silty, semi-consolidated.

Bottom of core 71.60-71.99m--Yellow-brown clay (10 YR 5/5), non-calcareous.

Bottom of core 73.12-73.27 m--Medium brown (10 YR 5/5).

Bottom of $73-\mathrm{m}$ interbed at $73.27 \mathrm{~m}$, in solid basalt. 
$76-4-1$

$3.60-4.18 \mathrm{~m}$

$76-4-2$

$5.03 \mathrm{~m}$
Diagonal and vertical fractures in vesicular to moderately dense-gray basalt. Fractures filled with 1 ight brown to tan fine-sedimentary material (10 YR 7/3).

Deposit appears mottled--with 1 ight-tan material around what may be root tubes or worm burrows. Deposit up to $1 \mathrm{~cm}$ thick in portions of fracture.

Open fracture, both horizontal and diagonal--no lining or filling material.

$3.60 \mathrm{~m}$

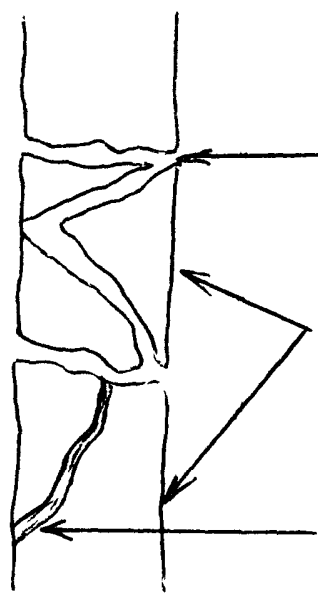

Al 1 fractures 1 ined and filled with $\mathrm{CaCO}_{3}$-rich fine clay.

No material coarser than clay.

$4.18 \mathrm{~m}$ $\mathrm{CaCO}_{3}-\mathrm{rich}$ fracture filling material.

Horizontal fracture in 1 ight-gray dense basalt filled with sedimentary material. Looks slightly layered with silt-size material and brown overlying light tan carbonate ( 5 YR 7/2).

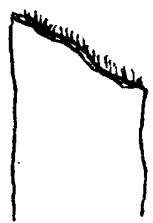

Top of "9-m sediment interbed".

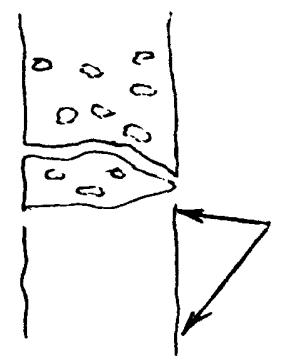

See blow-up on next page for sed iment ary material $(6.0-6.58 \mathrm{~m})$.

Medium-gray vesicular basalt underlain by brown to red-brown clay. 


$76-4-3(a)$
$6.10-6.25$
$76-4-3(\mathrm{~b})$
$6.25-6.58$

$76-4-4$
$7.01 \mathrm{~m}$
$76-4-5$
$7.47 \mathrm{~m}$
$76-4-7$
$19.96 \mathrm{~m}$
$76-4-6$

Dark brown, moist sedimentary material
$(10$ YR 4/3), possible soil zone.
Mottled zone.

Upper dark-brown zone has earthy odor, very lightly calcareous. Lower unit-fine silt, very slightly calcareous.

Dark-brown silt, soil odor(?). Bottom of 9-m interbed, slightly calcareous (10 YR 6/2).

Sed iment-filled horizontal fracture in medium vesicular dark-gray basalt, very slightly calcareous. Light-tan clay (10 YR 6/3) about $1 \mathrm{~cm}$ thick.

Fractures, diagonal, unl ined--in light-gray dense basalt.

Light-tan clay linings on fractures in vesicular red-brown basalt ( 10 YR 8/2)--all clay coatings are thin, none of the vesicles or fractures are filled.

Evidence of several sequences of sedimentary input to diagonal fracture in red-brown vesicular basalt.

Light-tan clay (10 YR 8/2) lining some of the vesicles above and below fracture and also 1 ining the surface of fracture. These coatings are then covered by $f$ ine silt; possible evidence of thick episode in coarser ( $f$ ine sand) material in part of fracture.

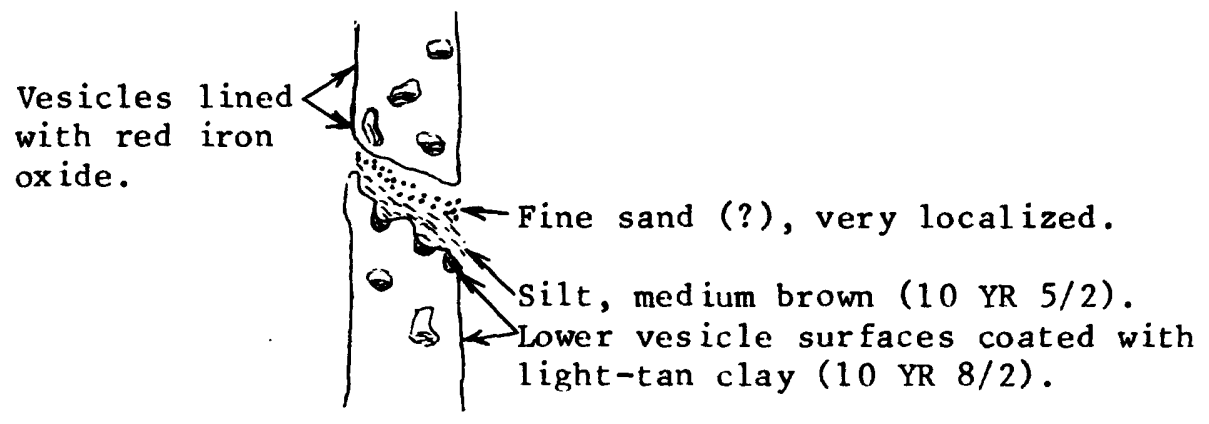

Clay up to $0.7 \mathrm{~cm}$ thick one fracture surface; silt deposits that thick in other locations. Calcareous. 
76-4-8

$20.70 \mathrm{~m}$

$76-4-9$

$22.95 \mathrm{~m}$

$76-4-10$

$21.18-22.22 \mathrm{~m}$

76-4-11

$23.8-24.72 \mathrm{~m}$

$76-4-12$

$29.93-30.78 \mathrm{~m}$
Multi-episode fracture filling. Medium-brown silt above and below 1 ight-tan clay (10 YR 8/2) in horizontal fractures.

Clay 1 ined horizontal fracture between dense 1 ight-gray basalt $(5 \mathrm{Y} 7 / 2)$ and vesicular 1 ight-gray basalt. Slightly calcareous.

Series of sediment-1ined fractures in 1ight-gray coarsely vesicular basalt. Some vesicles show laminations in geopetal fabric of clays $(5 Y 7 / 2)$.

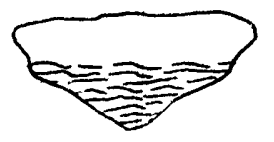

Series of vertical and diagonal fractures in moderately dense 1 ight medium-gray basalt. Some fractures clean (no coatings or minimal coatings), some 1 ined with clay, 1 ight tan ( 5 Y $7 / 2$ ).

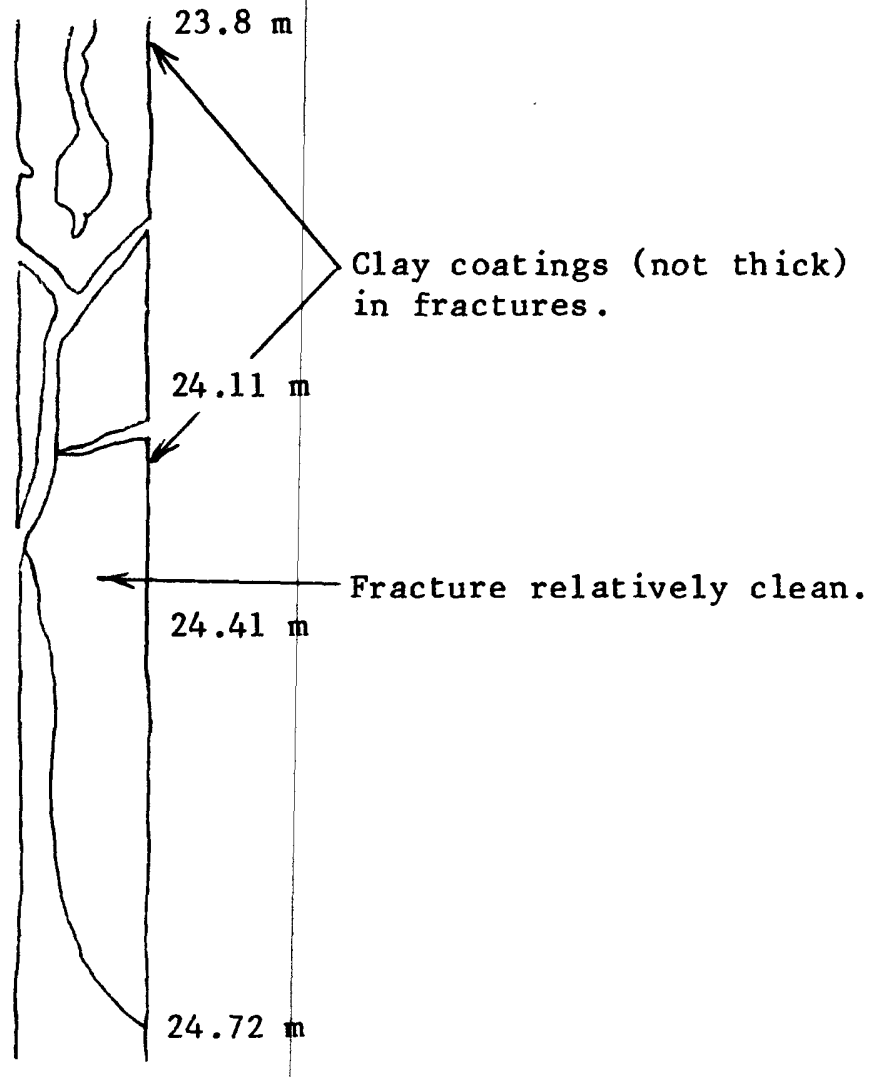

34-m interbed--very thin, highly calcareous, $\mathrm{CaCO}_{3}$ cemented base of sediment interbed and top $0.3 \mathrm{~m}$ of fractured red-brown vesicular basalt. 


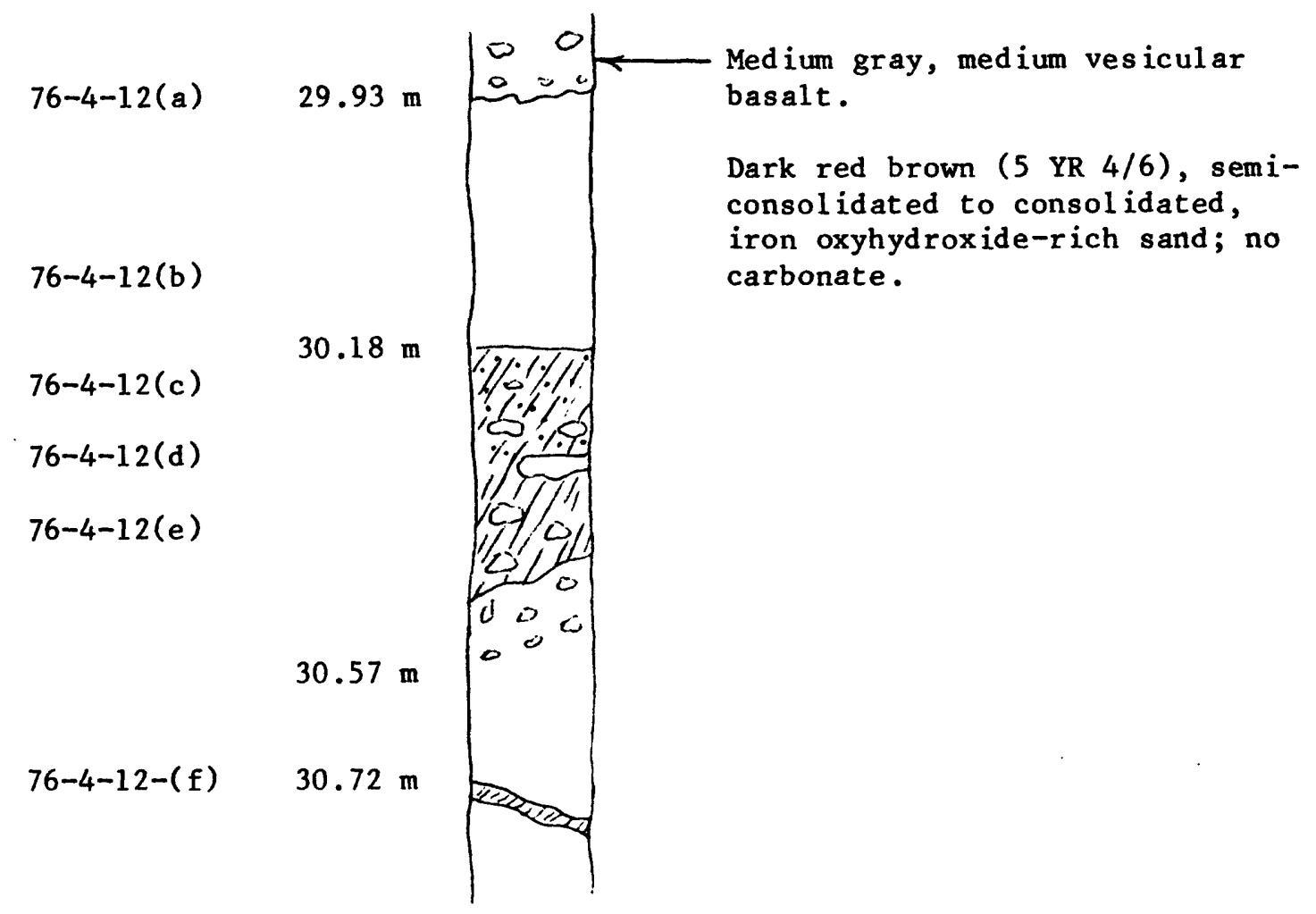


WELL $76-4 \mathrm{~A}$

$76-4 \mathrm{~A}-1$

$3.47 \mathrm{~m}$

76-4A-1(a) Upper surface ( 5 Y 8/1).

$76-4 A-1(b) \quad$ Lower surface $(5 \quad Y 7 / 2)$.

$76-4 A-2$

$4.02 \mathrm{~m}$

$76-4 \mathrm{~A}-3$

$4.94 \mathrm{~m}$

$76-4 A-4$

$76-4 \mathrm{~A}-5$

$7.04-8.08 \mathrm{~m}$

(See sketch).
Horizontal fracture in moderately coarse vesicular medium-gray basalt. Lined with fine-sedimentary material. Highly calcareous.

Fracture filling material may be almost all carbonate-on the upper surface at least.

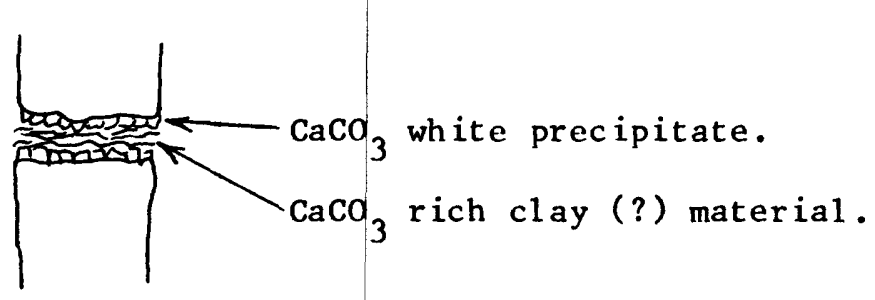

Vertical fracture coating material ( $5 \mathrm{Y} 6 / 2$ ).

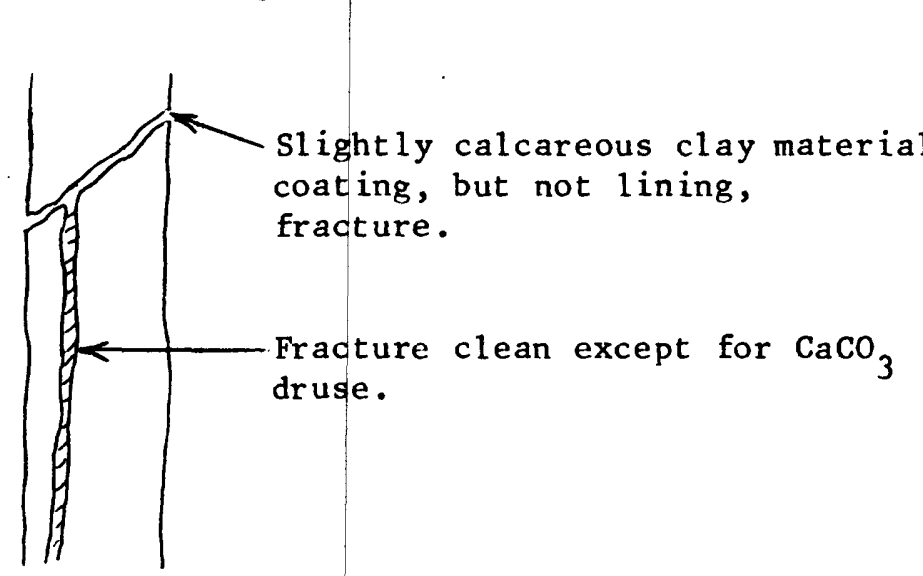

Horizontal fracture in 1 ight gray, dense basalt 1 ined with 1 ight-tan fine-material $(5 \mathrm{Y} 6 / 2)$. Non-calcareous.

Diagonal fracture in 1 ight-gray dense basalt filled with light-tan fine material $(5 \mathrm{Y} 7 / 2)$. Non-calcareous.

Top of "9-m interbed" at $7.04 \mathrm{~m}$. 


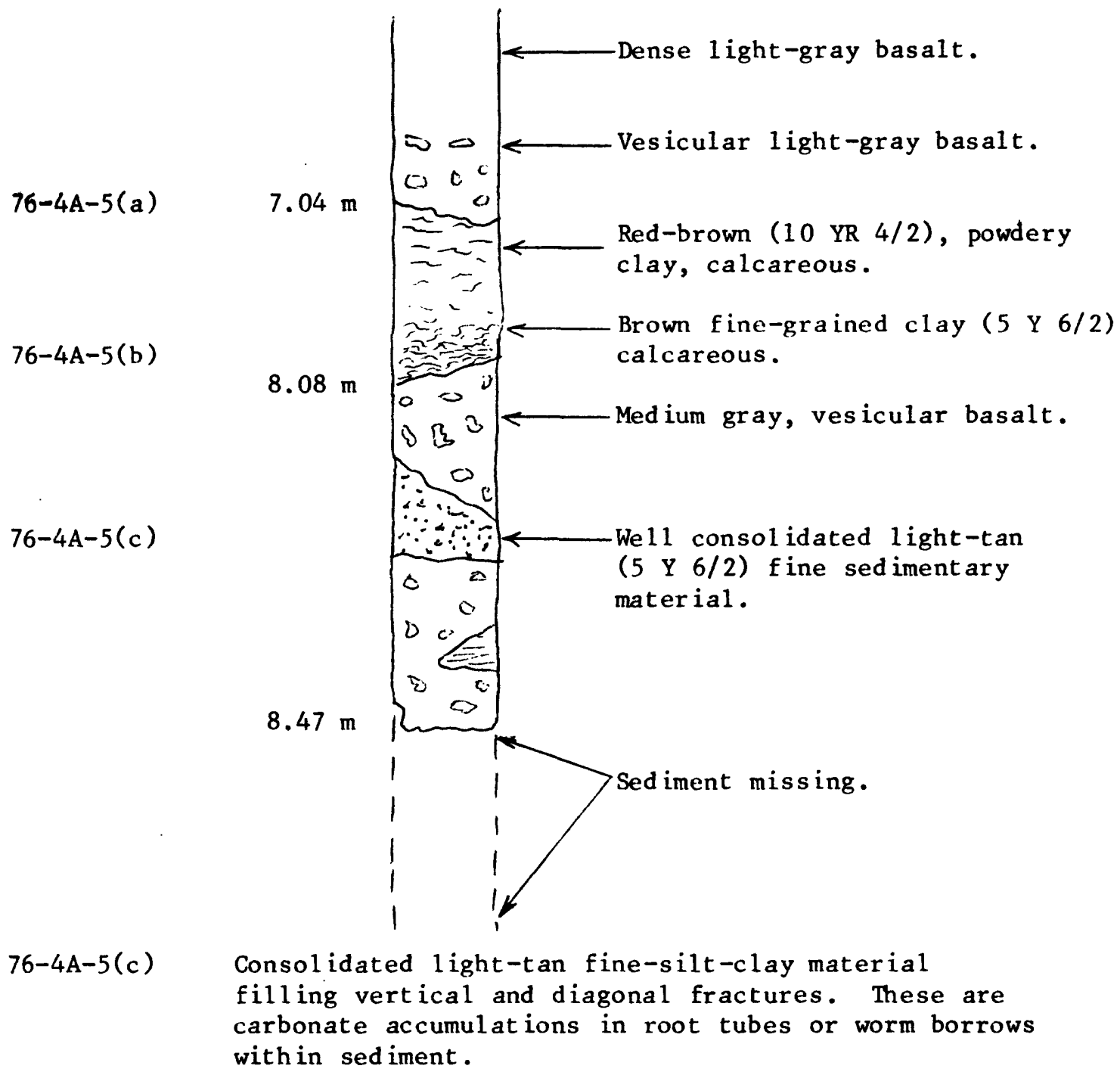

Side view

$76-4 A-6$

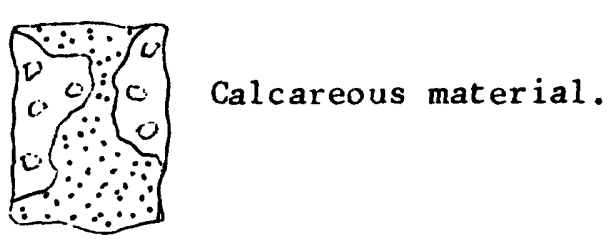

$16.43 \mathrm{~m}$

Diagonal fracture in slightly vesicular brown basalt. Fracture filled with light brown, clay-silt material (5 $\mathrm{Y} 7 / 2)$. Series of diagonal fractures with some orientation contain 1 ittle or no sedimentary material. 
$76-4 A-7$ $23.59 \mathrm{~m}$

$76-4 \mathrm{~A}-8$ $29.84 \mathrm{~m}$

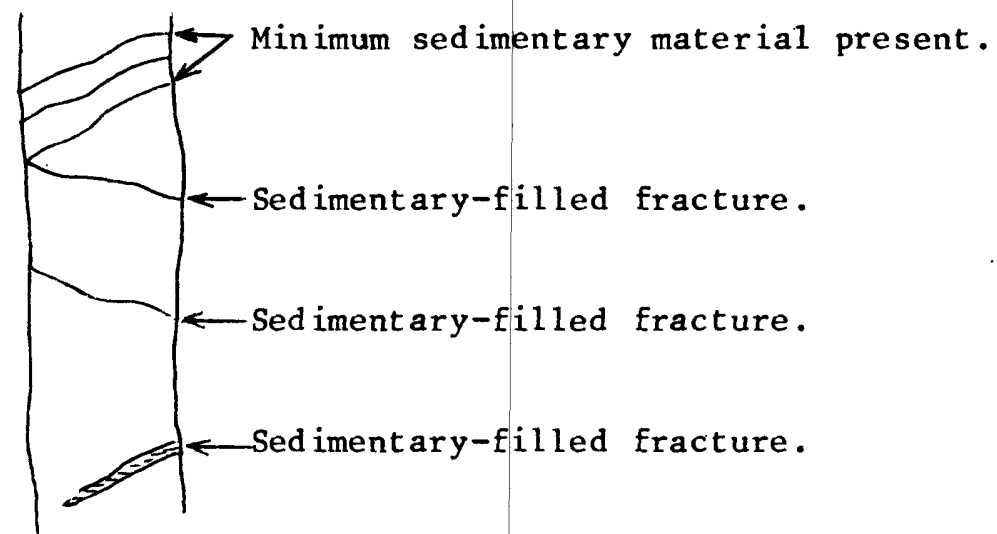

Diagonal fractures in slightly vesicular light-gray basalt, some vesicles filled with clay forming clay balls ( 5 Y $7 / 2)$.

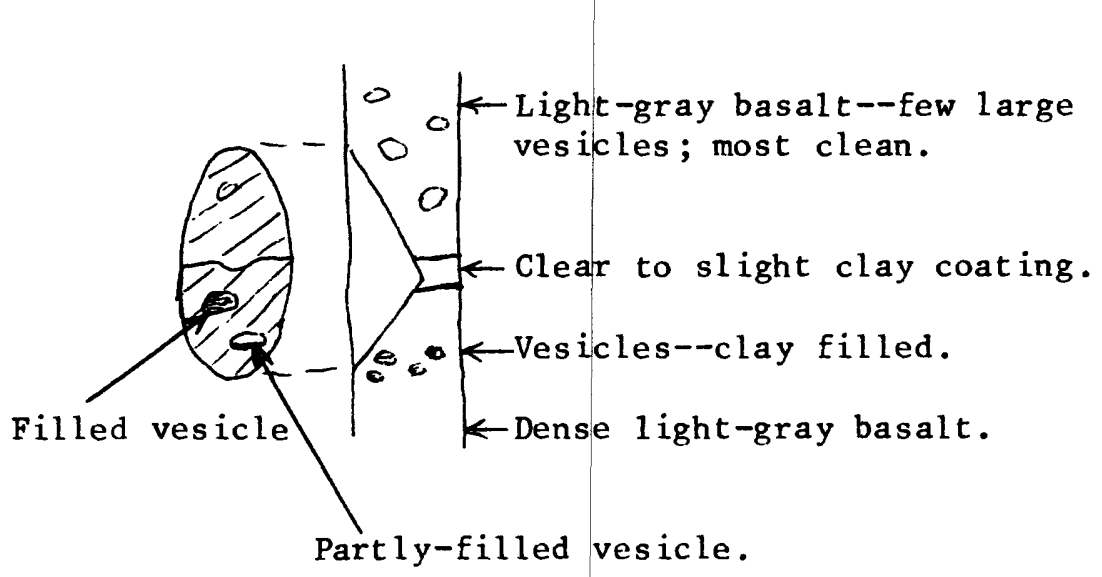

Surface slightly clay coated, calcareous.
Contact representative of "34-m sedimentary interbed". $39.84 \mathrm{~m} \mid \begin{aligned} & \text { Vesicular medium-gray basalt containing } \\ & \text { Eractures and vesicles lined with light- } \\ & \text { tan layered clay. }\end{aligned}$ 


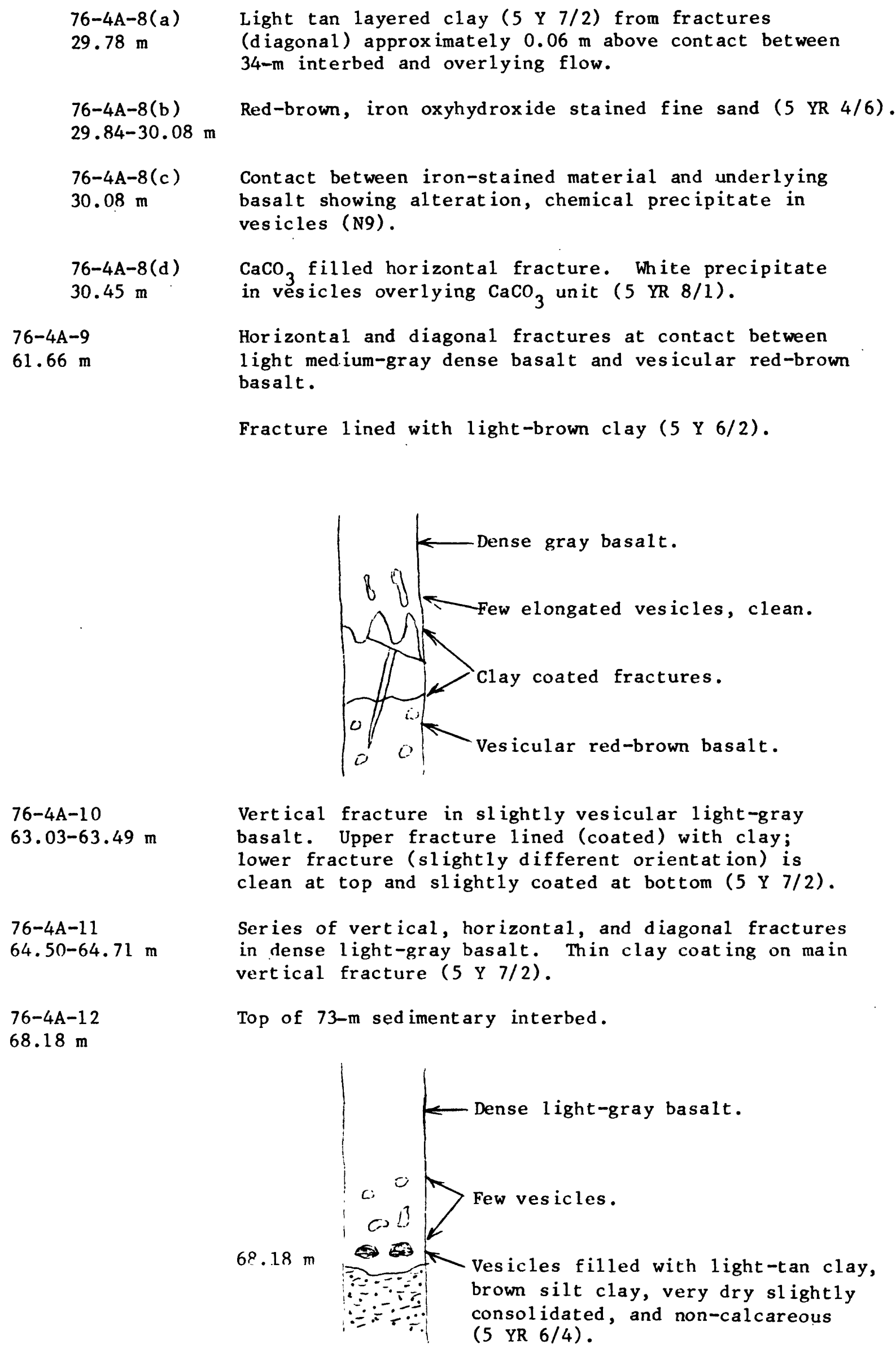


76-4A-12(a) Light-tan clay from vesicles above contact (10 YR 8/2).

$76-4 A-13$

$69.49 \mathrm{~m}$

$76-4 A-14$

$70.29 \mathrm{~m}$

$76-4 A-15$

$70.81 \mathrm{~m}$

$76-4 A-16$

$71.14 \mathrm{~m}$

$76-4 \mathrm{~A}-17$

$71.60 \mathrm{~m}$

$76-4 A-18$

$72.21 \mathrm{~m}$

$76-4 \mathrm{~A}-19$

$72.51 \mathrm{~m}$

$76-4 A-20$

$73.03 \mathrm{~m}$

$76-4 A-21$

$73.46 \mathrm{~m}$

$76-4 A-22$

$73.82 \mathrm{~m}$

$76-4 A-23$

$74.19 \mathrm{~m}$
Brown plastic clay, slight silt content--moist and calcareous (5 YR 5/6).

Brown plastic clay, calcareous, moist, slightly silty (5 YR 6/4).

Brown plastic clay, non-calcareous ( 5 YR 5/6).

Brown, fine sandy silt, non-calcareous (5 YR 4/4).

Brown, medium sand, non-calcareous (5 YR 4/4).

Brown, medium to fine sand with clay lenses(?) noncalcareous (5 YR 4/4).

Brown, silty clay, non-calcareous (5 YR 5/6).

Brown plastic clay, non-calcareous (5 YR 6/4).

Brown clay, non-calcareous ( 5 YR 4/4).

Brown, silty clay, non-calcareous (5 YR 4/5).

Brown, silty clay, non-calcareous (5 YR 4/4). 


\section{WELL 76-5}

76-5-1

$3.54 \mathrm{~m}$

$76-5-2$

$5.21 \mathrm{~m}$

$76-5-3$

$6.89 \mathrm{~m}$
Diagonal fracture in light-medium gray vesicular basalt. Fracture 1 ined with fine-medium grained material--slightly calcareous (10 YR 4/3).

Medium quartz with fine carbonate-clay material for matrix--clay carbonate 1 ining top and bottom walls of fracture.

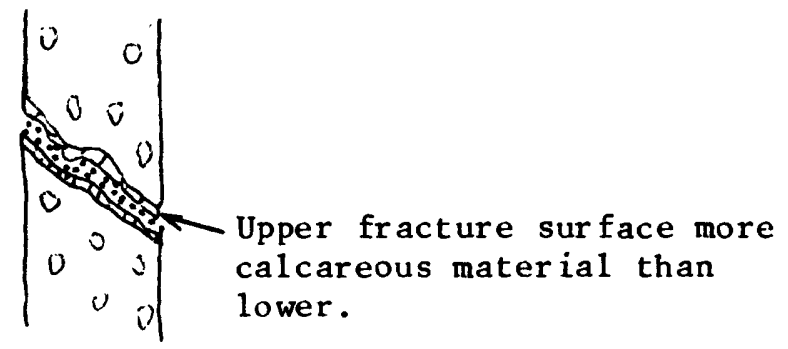

Vesicles cut by fractures filled with sand over clay linings.

Series of diagonal fractures in dense medium-gray basalt filled with 1 ight-tan clay to silty material ( 5 Y $7 / 2$ ).

Sedimentary material in part welds fractures closed. Good evidence of several episodes of fracture fillingcoarser material in center of fracture.

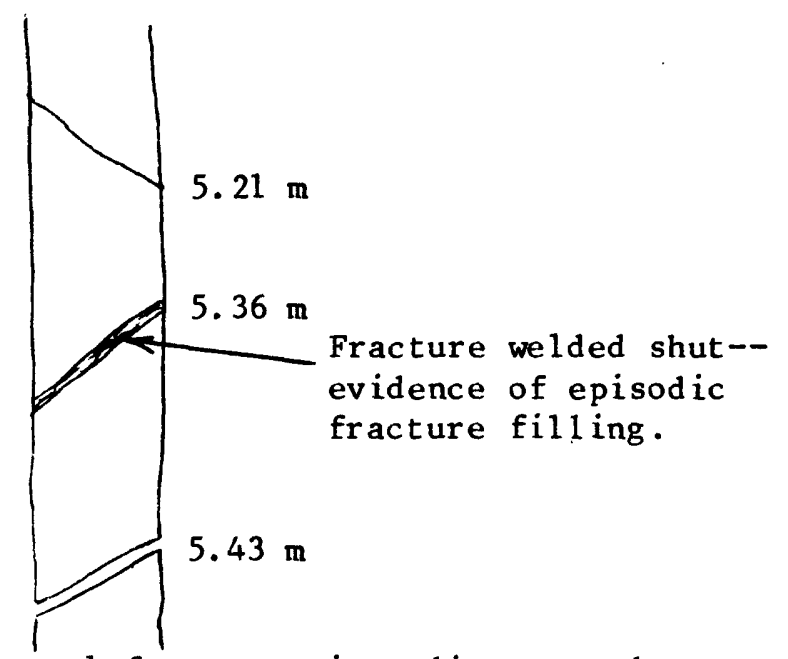

Vertical and diagonal fractures in medium-gray dense basalt fractures filled with gray-brown quartz silt and clay (5 Y $7 / 2)$. 


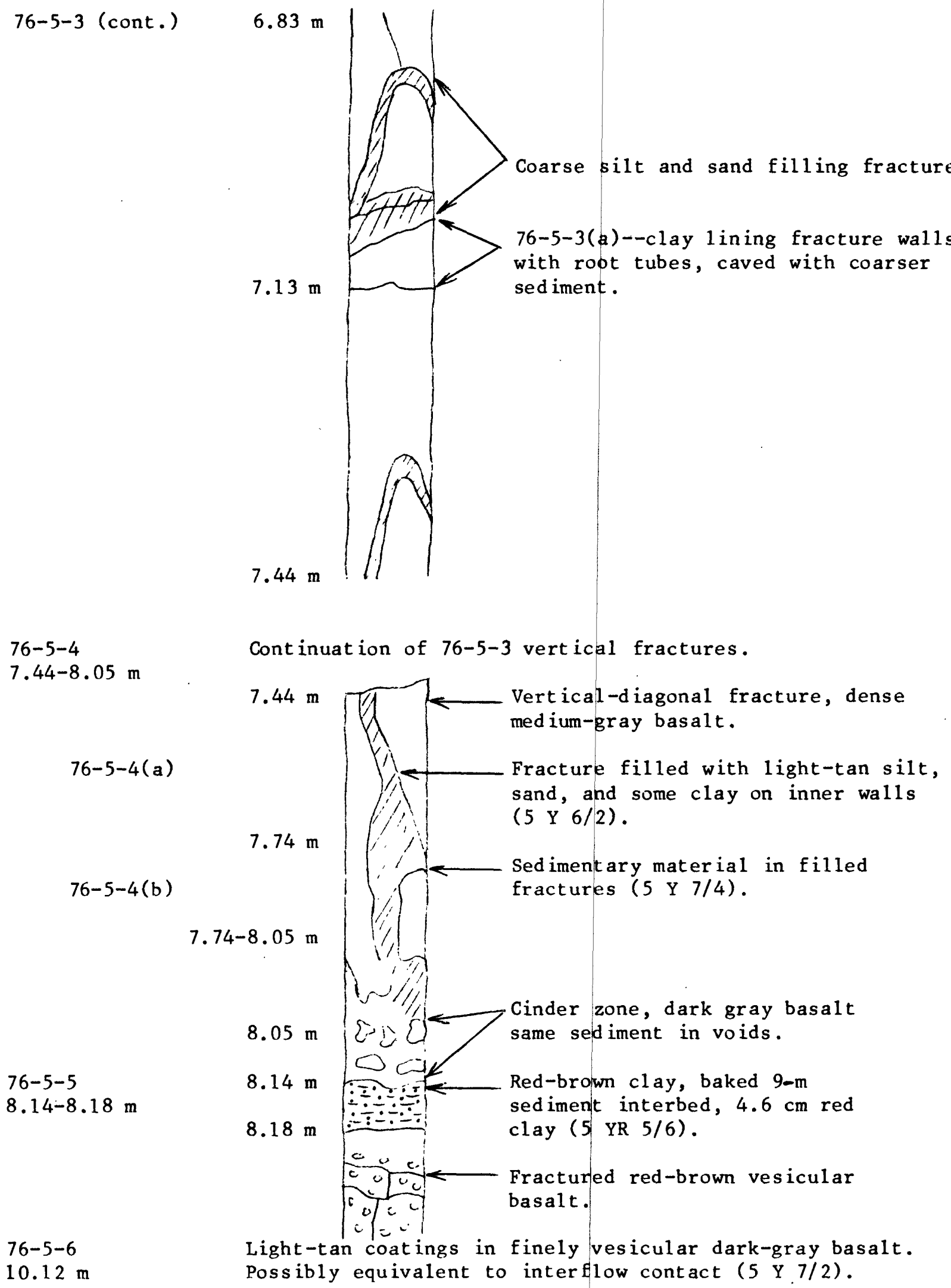


$76-5-7$

$11.70 \mathrm{~m}$

76-5-9

13-05 m

$76-5-8$

$14.48 \mathrm{~m}$

$76-5-10$

$15.82 \mathrm{~m}$

$76-5-11$

$17.19-17.65 \mathrm{~m}$

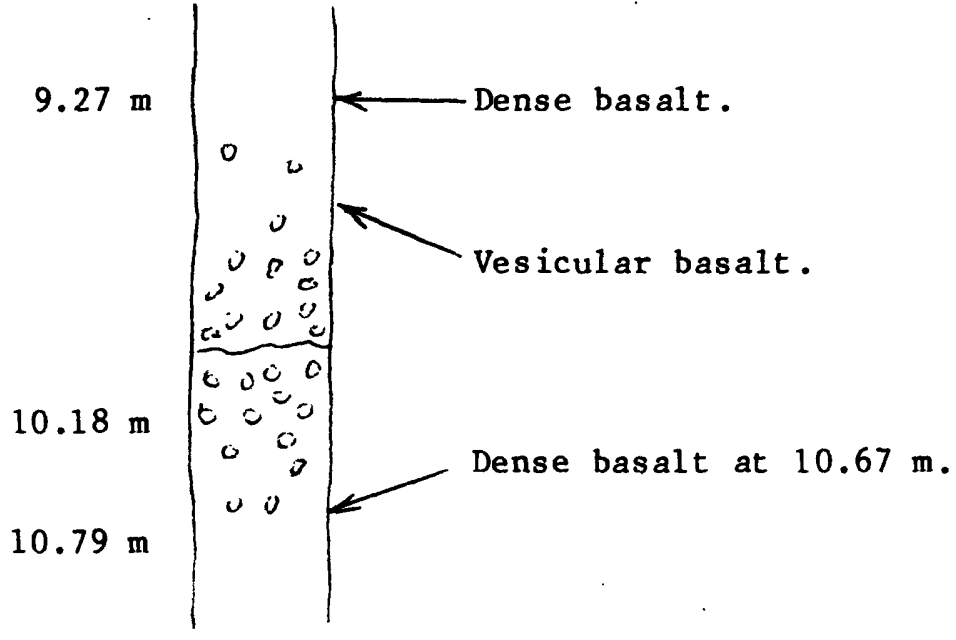

Light-tan clay lining horizontal fracture in vesicular basalt ( $5 \mathrm{Y} 6 / 1)$. Possible contact between medium gray, medium vesicular basalt and red-brown medium vesicular basalt.

Horizontal fracture in vesicular basalt at top(?) of flow, 1 ight-brown tan clayey material (5 $\mathrm{Y} 7 / 2$ ).

Vertical diagonal and horizontal fractures at base of flow in vesicular gray-brown basalt. Light-tan clay in vertical diagonal fractures ( $5 \mathrm{Y} 7 / 1$ ).

Brown to light-tan sedimentary filling intersecting vertical and horizontal fractures in vesicular dark medium-gray basalt (10 YR 7/3).

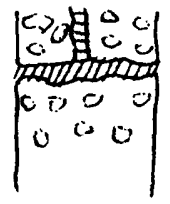

Light-tan clayey material (10 YR 6.5/3) in a series of diagonal, vertical, and horizontal fractures in medium gray dense to slightly vesicular basalt. Horizontal fracture artifacts of drilling.

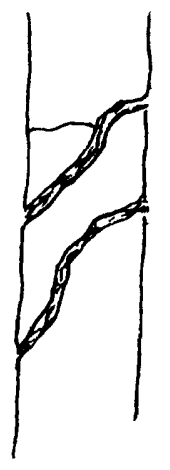


$76-5-12$

$21.03 \mathrm{~m}$

$76-5-13$

$22.92-23.41 \mathrm{~m}$
Horizontal fracture in gray-brown vesicular basalt, 1 ight-tan, clay coated (10 YR 8/2).

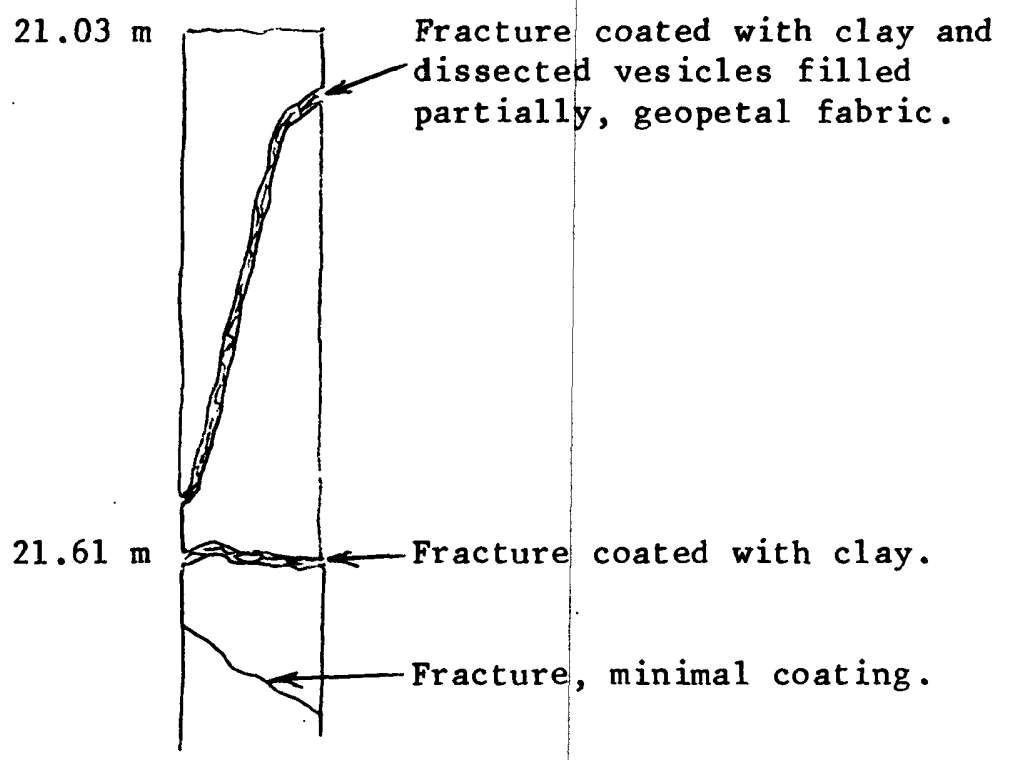

Series of diagonal, vertical, horizontal fractures in slightly vesicular light medium-gray basalt clay coating all and filling most fractures (5 YR 6/2).

$22.92 \mathrm{~m}$

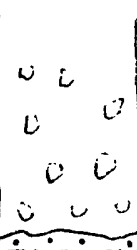
$\div \div \div$ Sedimentary material.

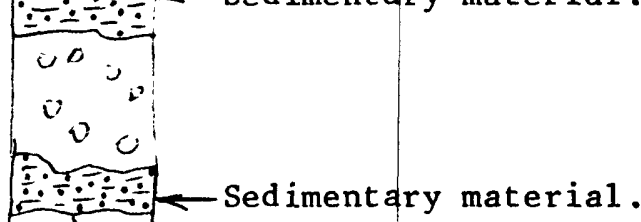

$23.41 \mathrm{~m}$

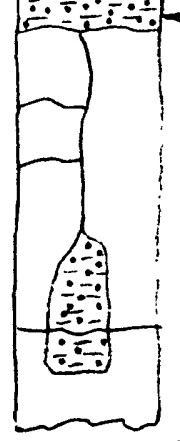

Entire surface of core very dirty--looks 1 ike core contained water when drilled through. 
$76-5-14$

$24.46-24.77 \mathrm{~m}$

$76-5-15$

$25.76 \mathrm{~m}$

$76-5-16$

$26.24-26.82 \mathrm{~m}$
Diagonal fracture in dense medium-gray basalt; bottom $20.3 \mathrm{~cm}$ is welded together by material in fracture (10 YR 7/2).

Sampl ing

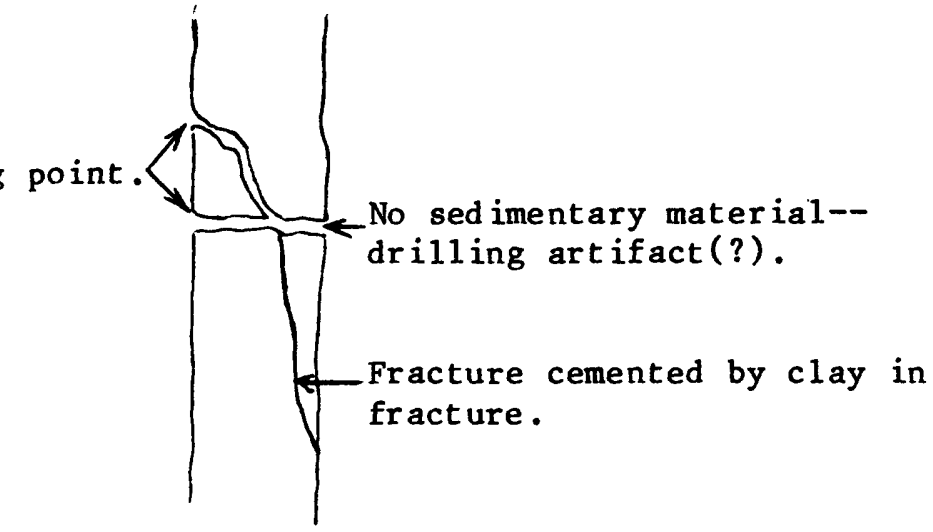

Intersection of two diagonal fractures in medium-gray dense basalt. Light tan clay (5 YR 6/2) filling fractures were saturated when removed from core barrel(?), shows imprint of glove material used for handling core.

Light-tan clay coated with 1 ight-gray basalt dust from drilling.

Vertical-diagonal fractures in medium-gray dense basalt. Light-tan clay filling fractures (10 YR 7/2).

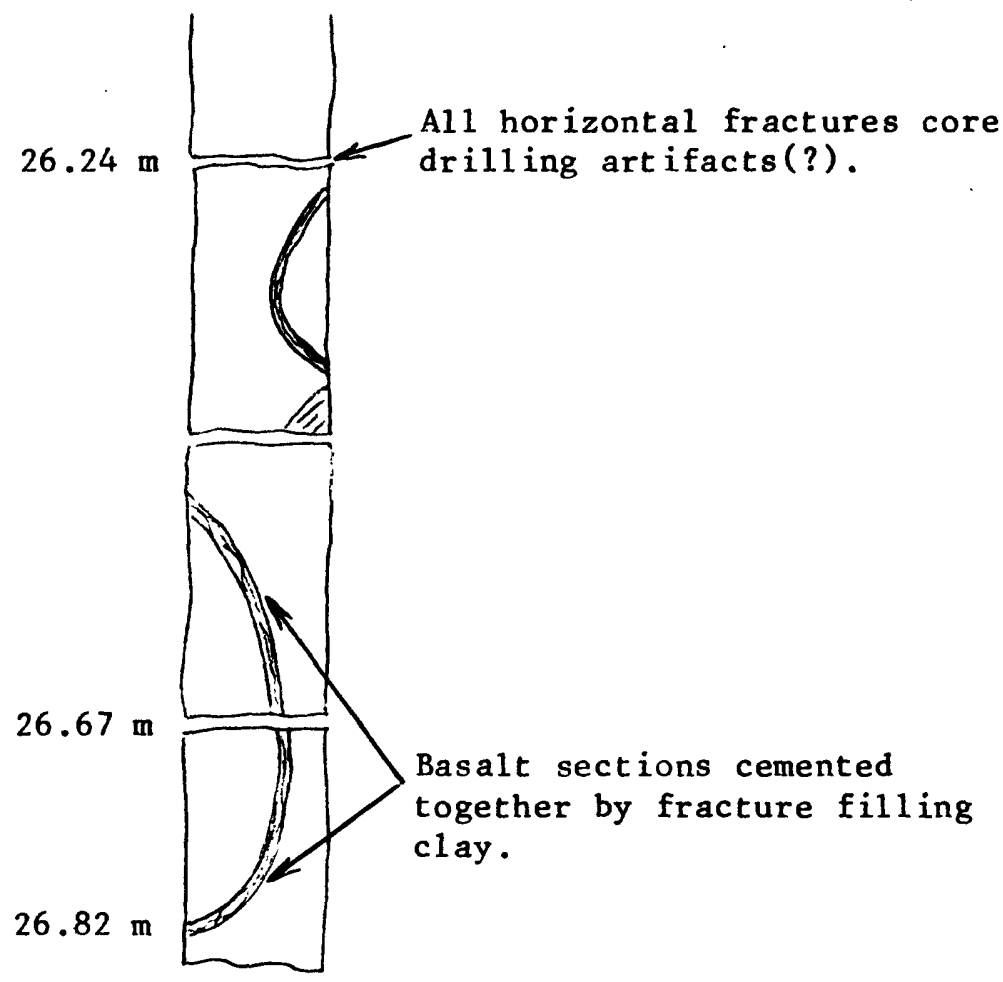


76-5-17

$27.49-27.80 \mathrm{~m}$

$76-5-17$

$76-5-18$

$76-5-19$

$76-5-20$
Series of diagonal fractures filled with light-tan clay in red-brown very vesicular basalt.

Sediment was saturated when drilled, evidenced by mud streaks on sides of core.

$27.74 \mathrm{~m}$

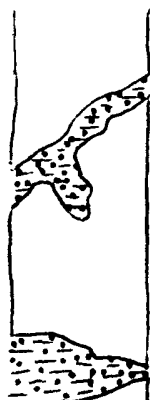

$27.43 \mathrm{~m}$

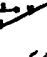

$c$

c. 0

0

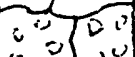

00,00

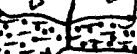

$28.04 \mathrm{~m} \mid \begin{array}{ccc}0 & 0 & 0 \\ 0 & 0 & 0 \\ 0 & 0 & 0 \\ 0 & 0 & 0\end{array}$ $=20$

Sedimentary material (10 YR 7/2).

$28.35 \mathrm{~m}$
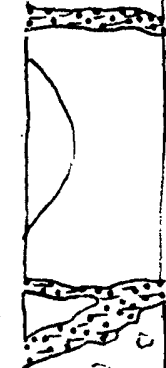

$28.65 \mathrm{~m}$ 0

Sedimentary material (10 YR 7/2).

\section{Sedimentary material (10 YR $7 / 2$ ).}

$28.96 \mathrm{~m}$

$$
\text { m }
$$

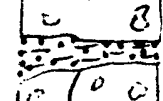$$
\mid \begin{array}{lll|}
0 & 0 & 0 \\
0 & 0 & 0 \\
0 & 0 & 0 \\
0 & 0 & 0
\end{array}
$$

Sedimentary material (10 YR $7 / 3$ ). 
76-5-21

$29.23 \mathrm{~m}$

76-5-22

$29.96 \mathrm{~m}$

76-5-23

$30.97 \mathrm{~m}$

76-5-24

$32.49 \mathrm{~m}$

76-5-25

$33.07 \mathrm{~m}$

76-5-26

$33.38-34.84 \mathrm{~m}$

76-5-27

34.84-34.99 m

76-5-28

$36.52-36.73 \mathrm{~m}$
Contact between basalt and $34-\mathrm{m}$ sedimentary interbed, brown sand, dark gray vesicular basalt.

Medium brown, slightly silty sand, quartz, noncalcareous ( 10 YR 5.5/5).

Medium brown slightly silty, very slightly calcareous, poorly sorted, few pebbles up to $0.5 \mathrm{~cm}$ (10 YR 5/4).

Light medium brown, silty fine sand; poorly sorted, gravel, few pebbles up to $0.25 \mathrm{~cm}$, slightly calcareous (10 YR 5/2).

Light brown silty fine sand ( 5 Y 6/3).

Recovered $0.30-0.15 \mathrm{~m}$ vesicular gray basalt, $0.15 \mathrm{~m}$ light brown fine sand, calcareous.

Light brown sandy clay (10 YR 6.5/3).

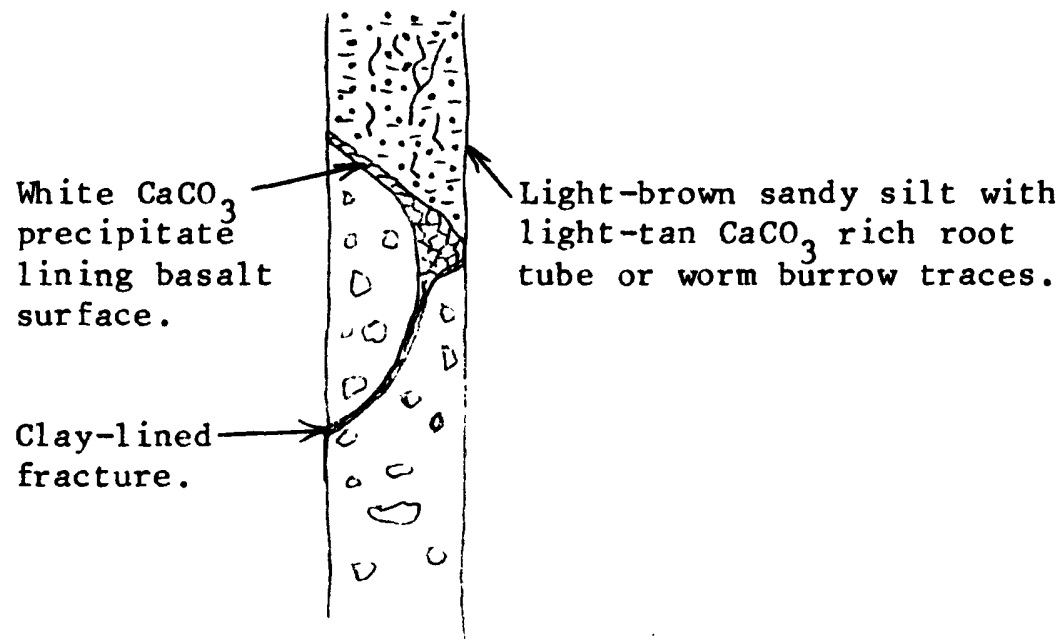

Light brown carbonate rich fine silty-clay (10 YR 6/5) filling vertical and diagonal fracture in dense to slightly vesicular medium-gray basalt. Carbonate coating upper and lower surface with some finely disseminated carbonate in sand filling center of void. Much less carbonate than on surface.

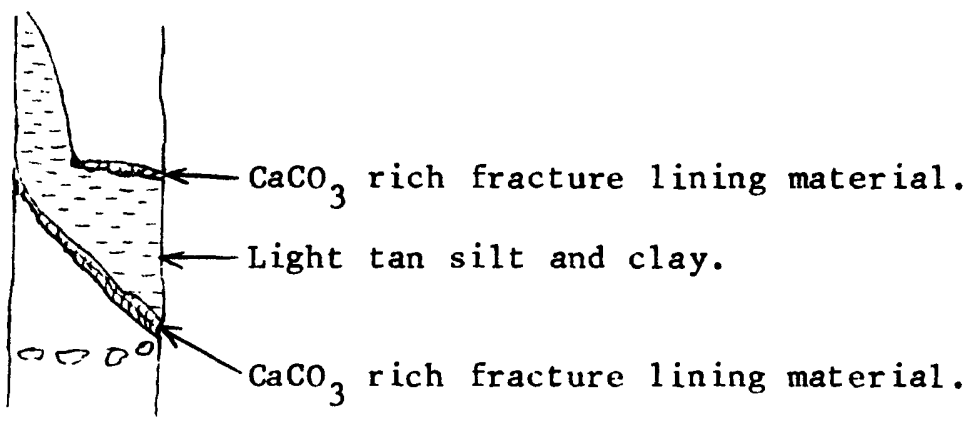


$76-5-29$

$64.00-65.47 \mathrm{~m}$
Clay coatings in series of fractures (vertical, horizontal, and diagonal) in extremely to slightly vesicular medium brownish-gray basalt (10 YR 7.5/3).

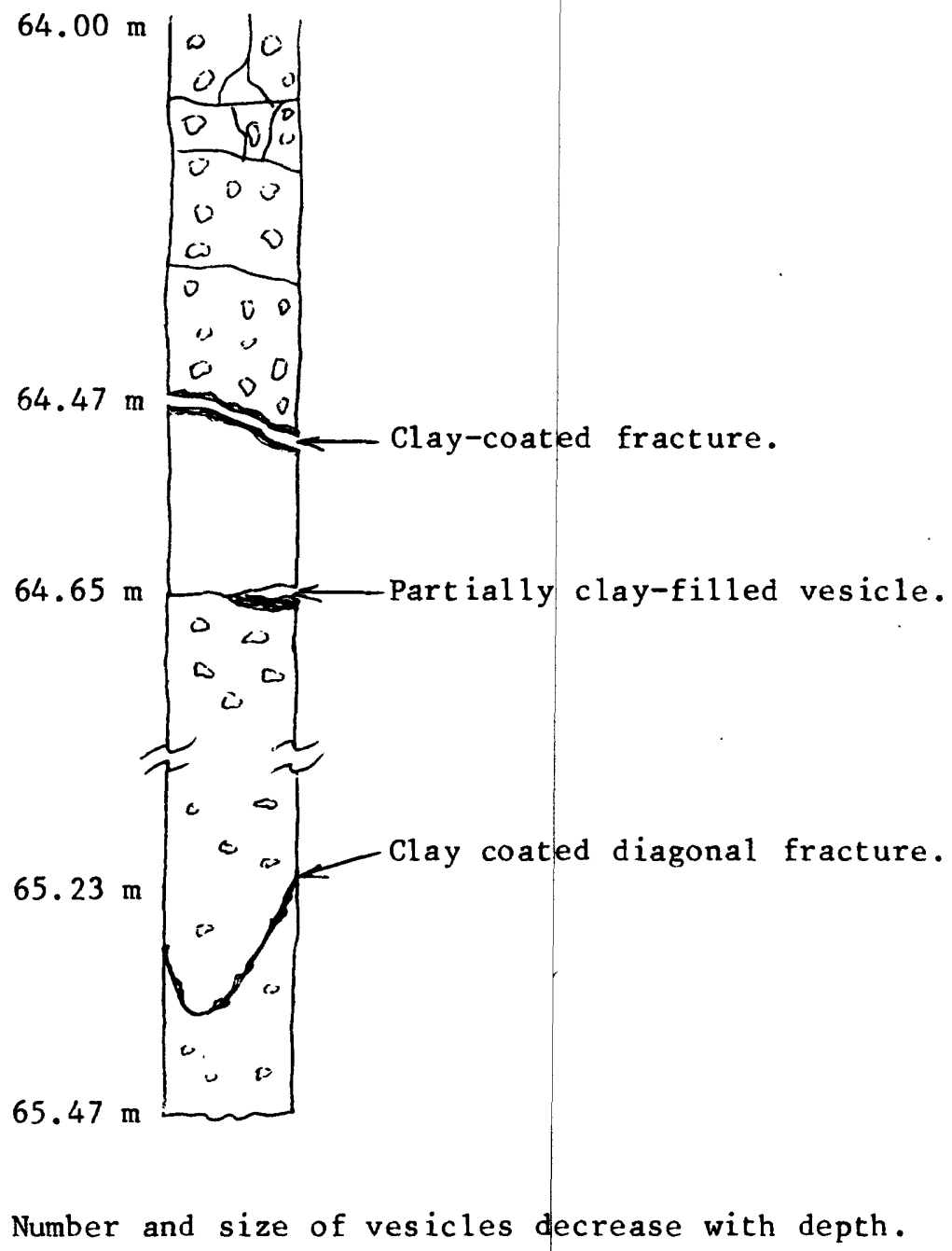

$76-5-30$

$67.79 \mathrm{~m}$
Top of 73-m sedimentary interbed contact between light reddish-brown silty clay (10 YR 5/4) semiconsolidated and dense medium gray basalt with few vesicles at base.

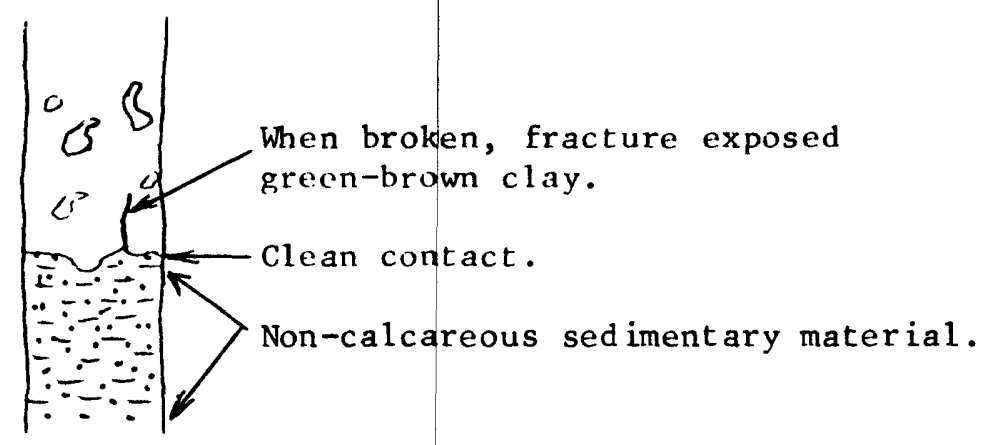


$76-5-30(a)$

$67.79 \mathrm{~m}$
Green clay in fractures in basalt immediately above contact of basalt and $73-m$ interbed ( 5 Y 7.5/3).

Green clay obviously moved down from above.

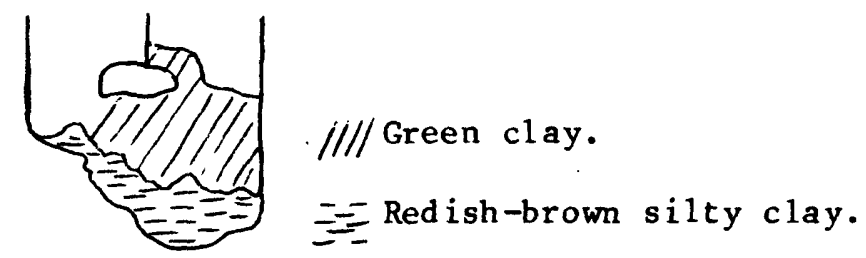

$76-5-31$

$68.64 \mathrm{~m}$

$76-5-32$

$69.46 \mathrm{~m}$

$76-5-33$

$70.20 \mathrm{~m}$

$76-5-34$

$71.02 \mathrm{~m}$

76-5-35

$71.90 \mathrm{~m}$

$76-5-36$

$72.66 \mathrm{~m}$

$76-5-37$

$73.52 \mathrm{~m}$

$76-5-38$

$73.82 \mathrm{~m}$
Dark brown, slightly calcareous, silty-fine sand, moderately well sorted (10 YR 5/5).

Dark brown calcareous silt, well sorted (10 YR 5/4).

Dark brown calcareous sandy silt and silty-fine sand (5. YR 4/4).

Medium brown, possibly slightly calcareous silt (10 YR 5/4).

Brown plastic clay (10 YR 5/4).

Dark brown plastic clay, slightly less plastic than sample 76-5-35 (10 YR 5/4).

Medium brown, plastic clay (10 YR 5/3).

Light medium-brown plastic clay (10 YR 5/3). 
WELL $76-6$

$76-6-1$

$3.69 \mathrm{~m}$

$76-6-2$

$4.60 \mathrm{~m}$
Vertical, horizontal, and diagonal fractures in vesicular, medium-gray basalt-top of flow.

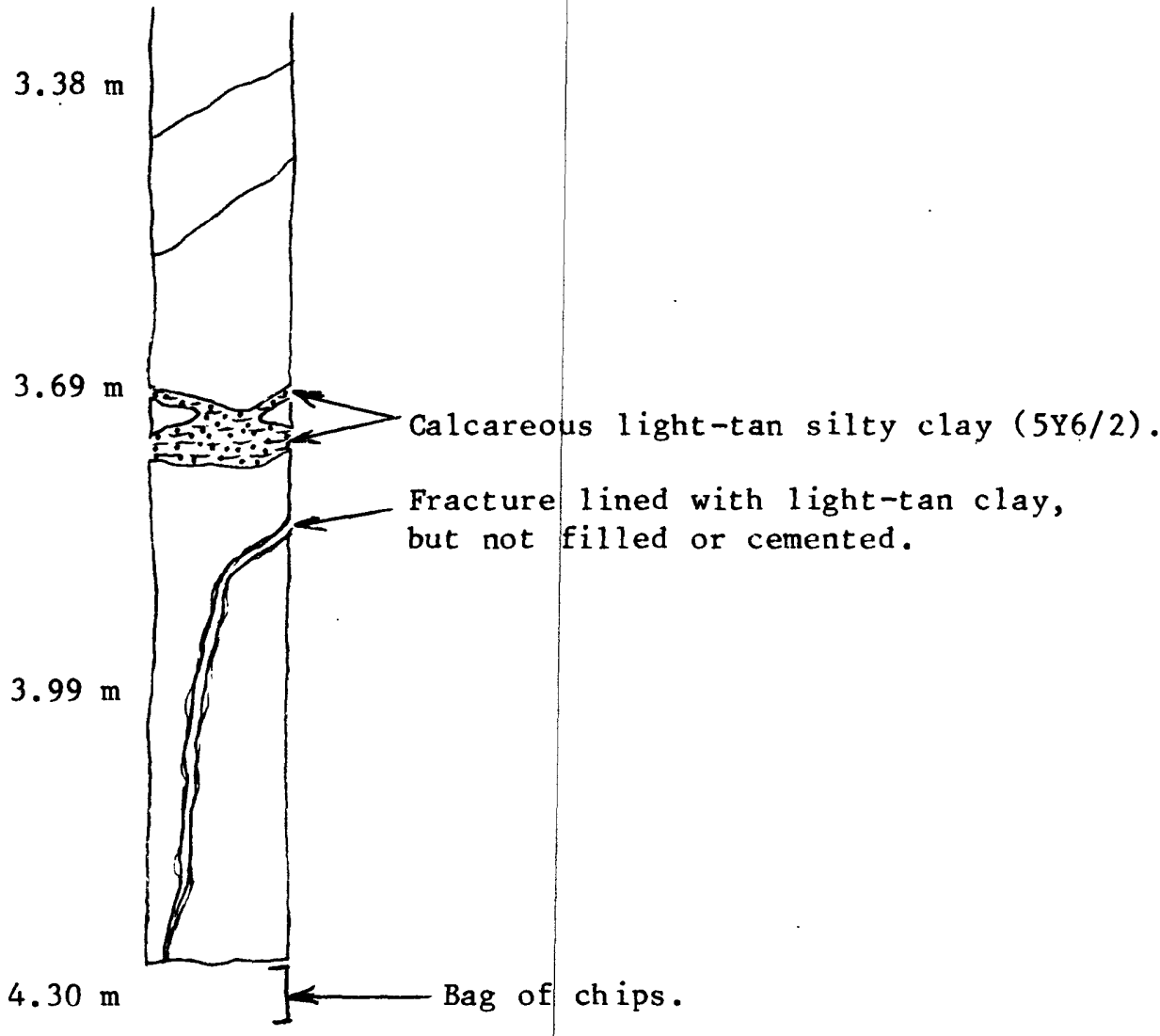

Looks like two episodes of fracture filling:

1. Light tan, very calcareouls clay such as 1 ining fracture from $3.75-4.30 \mathrm{~m}$; and

2. Brown-silty clay, calcareous.

Diagonal fracture in medium-gray dense basalt; upper surface $\mathrm{CaCO}_{3}$ precipitate coated, lower surface also $\mathrm{CaCO}_{3}$ coated.

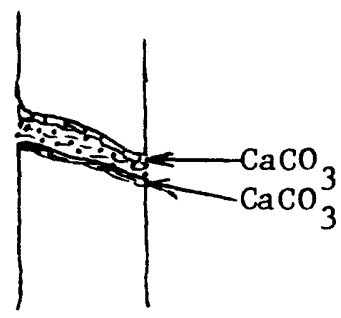

precipitate on upper surface. coating on lower surface. 


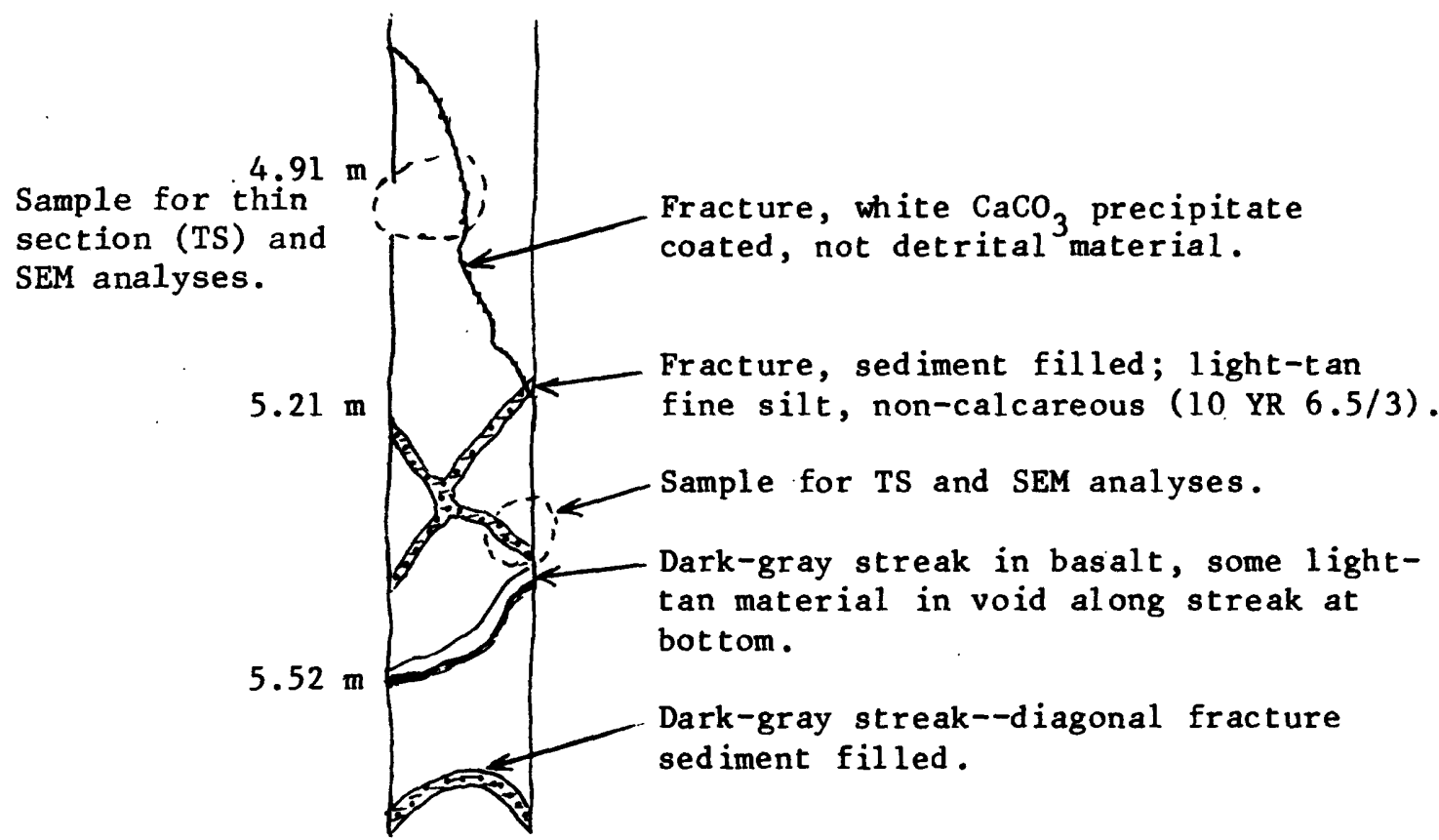

$76-6-4$

$7.41 \mathrm{~m}$

$76-6-5$

$14.90 \mathrm{~m}$
Diagonal fracture in medium-gray dense basalt, contains non-calcareous material, light-tan clay (5 Y $7 / 2)$.

Diagonal fracture in moderately dense portion of vesicular light to medium gray, basalt sequence.

Small amount of light-tan clay coating bottom surface of fracture, non-calcareous ( 5 Y $7 / 2$ ).

Very small amount of sedimentary material, 
$76-6-6$

$23.10 \mathrm{~m}$

76-6-7

$26.82 \mathrm{~m}$

$76-6-8$

$28.99 \mathrm{~m}$

$76-6-9$

$31.12-31.76 \mathrm{~m}$
Possible alteration of red-brown coarsely vesicular basalt. Light-tan coating in some vesicles, either chemical precipitate or some alteration--not sedimentary deposits.

Calcareous.

Diagonal fracture in medium-gray dense basalt, fracture surface coated with light-tan clay (5 Y 6/1).

Driller's log suggests weathering surface near this depth--no good evidence for such. There is some yellow-brown stain on the side of some pieces of core. Looks like may be related to zone saturated with $\mathrm{H}_{2} \mathrm{O}$.

\section{Calcareous.}

Diagonal fracture in medium-gray, dense basalt, 1 ined with light-tan clay (10 YR 8/2).

Calcareous.

"34-m sedimentary interbed"--Orange-brown to lighttan (10 YR6/4) sedimentary material underlying medium gray dense to vesicular basalt and overlying medium gray coarsely vesicular basalt.

Some significant portion of this interval was sampled for isotopic analysis, so stratigraphic significance is destroyed. Possibly significant mineralogically.

$31.12 \mathrm{~m}$

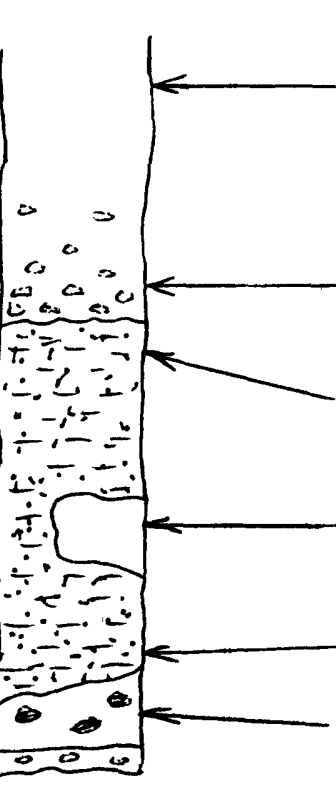

Vesicular medium-gray basalt. Dense basalt.

Sed imentary material.

Basalt in sedimentary material.

$31.76 \mathrm{~m}$ Red-brown, vesicular basalt with precipitate-filled vesicles.

Very slightly calcareous in part. 
76-6-10

$33.19 \mathrm{~m}$

$76-6-11$

$43.01-43.62 \mathrm{~m}$

$76-6-11(a)$
Diagonal fracture in medium-gray vesicular basalt filled with yellow-brown fine-silty material (10 YR 5.5/5).

$$
\left|\begin{array}{lll}
0 & 0 \\
0 & 0 & 0 \\
0 & 0 & 0 \\
0 & 0 & 0 \\
0 & 0 & 0 \\
0 & 0 & 0
\end{array}\right|
$$

Few vesicles immediately above fracture have sedimentary material in lower portion.

Diagonal, horizontal, and vertical fractures in medium red brown very vesicular basalt. Bottom of flow(?). Some 1 ight-tan alteration on upper surface of diagonal fracture, minimal sedimentary surface.

Fine material lining vertical fracture, same color as basalt; suspect drilling dust from air drilling basalt!

Non-calcareous (5 YR 5/1).

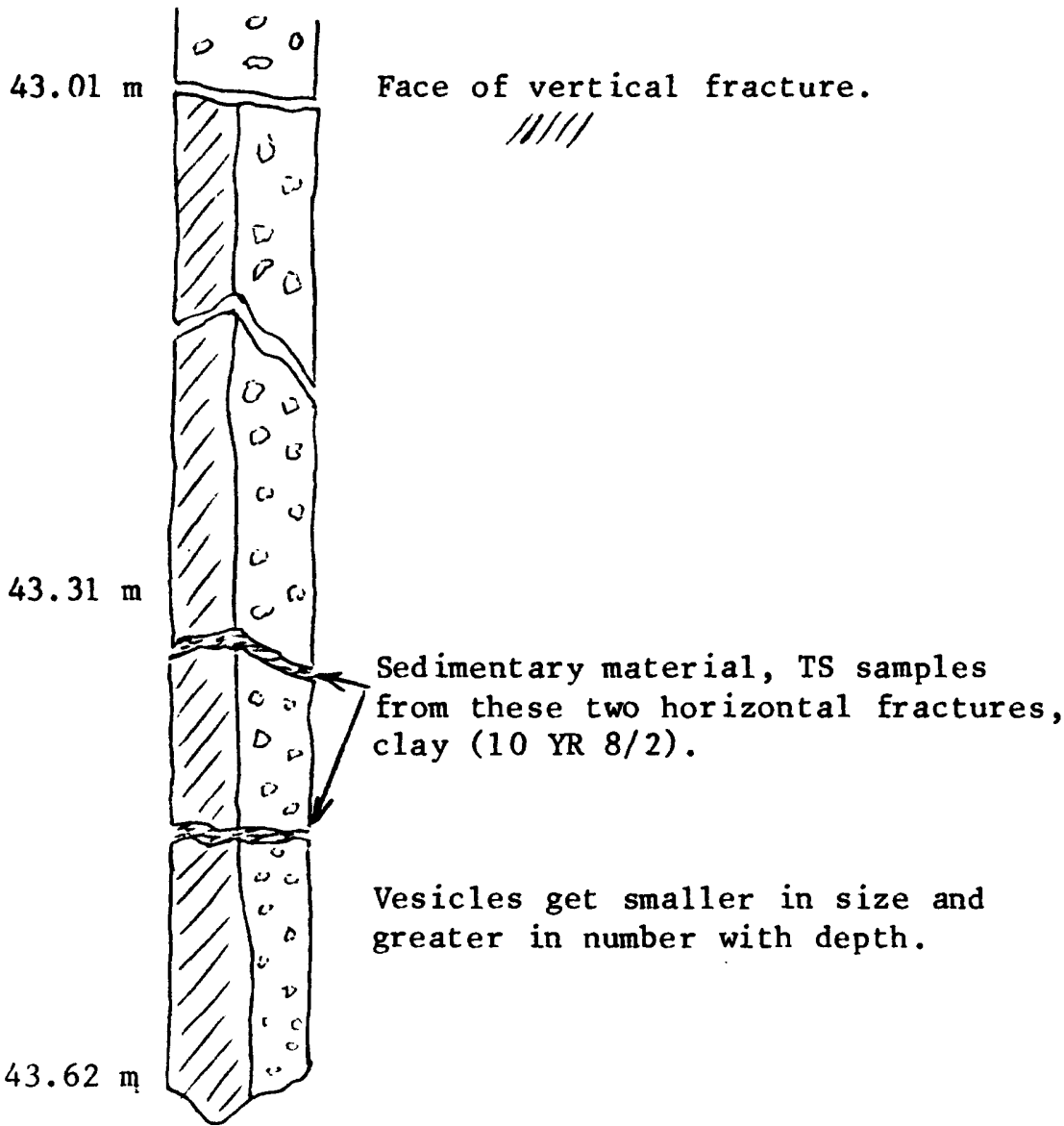


$76-6-12$

$43.83-44.23 \mathrm{~m}$

$76-6-13$

$57.33-58.77 \mathrm{~m}$
Series of diagonal, horizonta1, and vertical fractures, a continuation of those sampled as 76-6-11.

Most of material sampled appears to be basalt dust from drilling.

76-6-12(a) From lower diagonal fracture surface. Contains more sedimentary(?) material ( 5 Y $6 / 2$ ).

76-6-12(b) From upper diagonal fracture surface. Richer in basalt dust.

Non-calcareous (5 YR 5/1).

Possible flow contact at $54.01 \mathrm{~m}$.

Series of fractures in red-brown vesicular basalt slightly coated with 1 ight-tan clay (10 YR 7/2).

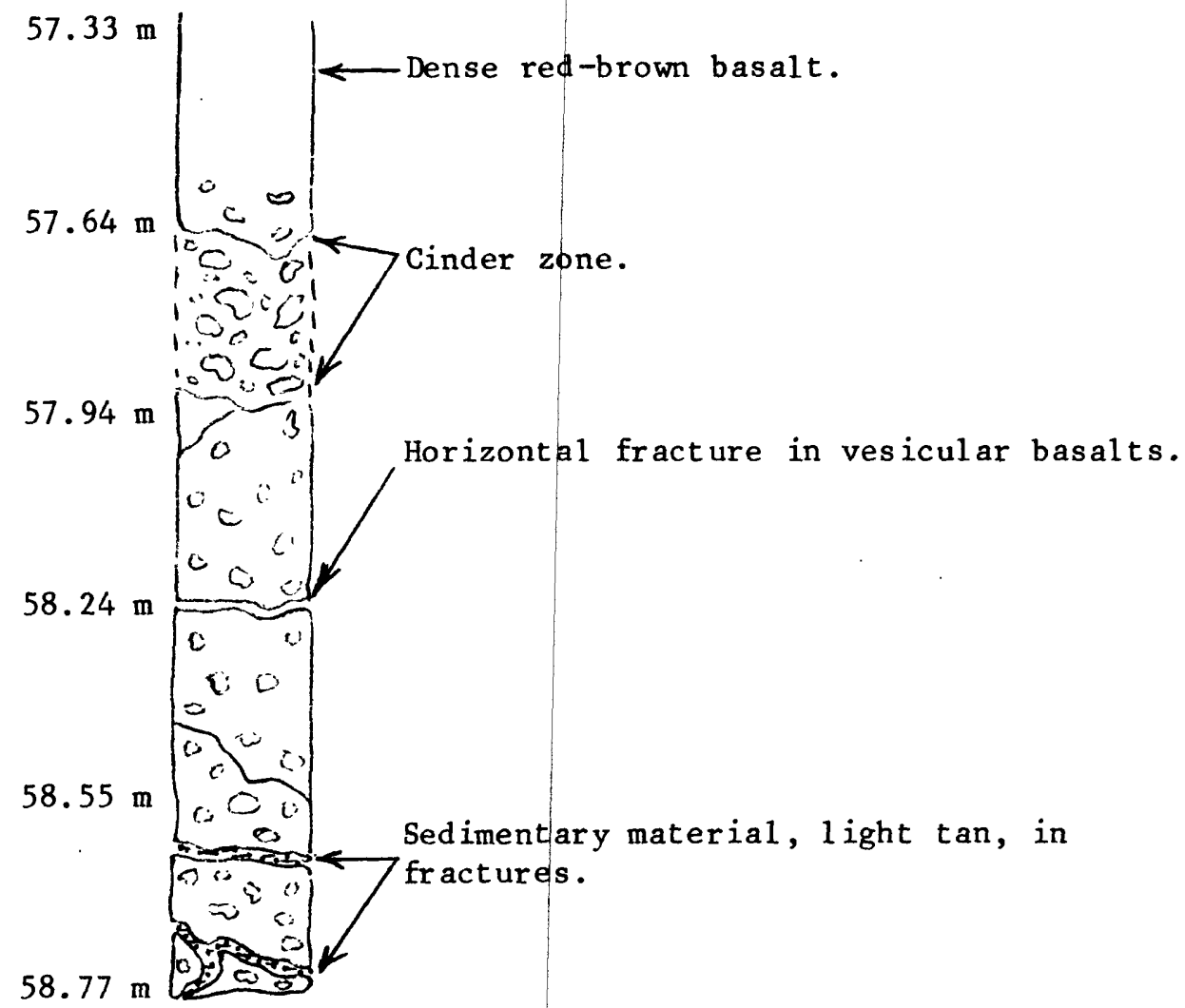


$76-6-14$

60.69-61.39 m

$76-6-15$

$61.48-61.81 \mathrm{~m}$
Sediment coating of vertical fracture surfaces, again combination of basalt drilling dust, light-tan water deposit, and sedimentary material (10 YR 7/2).
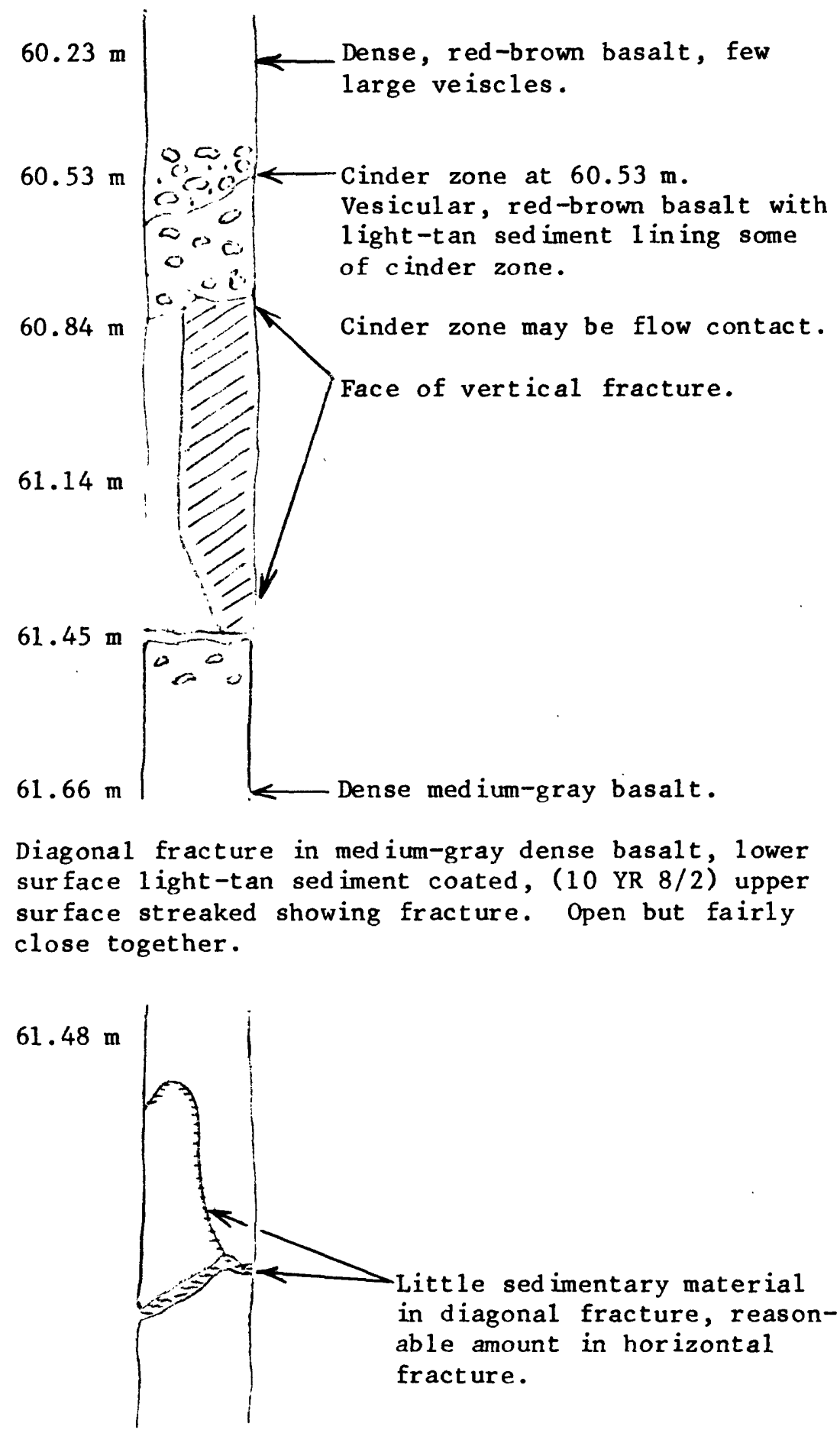

Few large vesicles, non-calcareous. 
$76-6-16$

$64.34-64.71 \mathrm{~m}$

$76-6-17$

$66.84-67.15 \mathrm{~m}$

$76-6-18$

$69.68-70.04 \mathrm{~m}$

$76-6-19$

$70.77 \mathrm{~m}$
Diagonal, vertical, and horizontal fractures in medium to coarsely vesicular basalt ( 10 YR $8 / 2)$, bottom of flow(?).

$64.47 \mathrm{~m}$

$64.71 \mathrm{~m}$

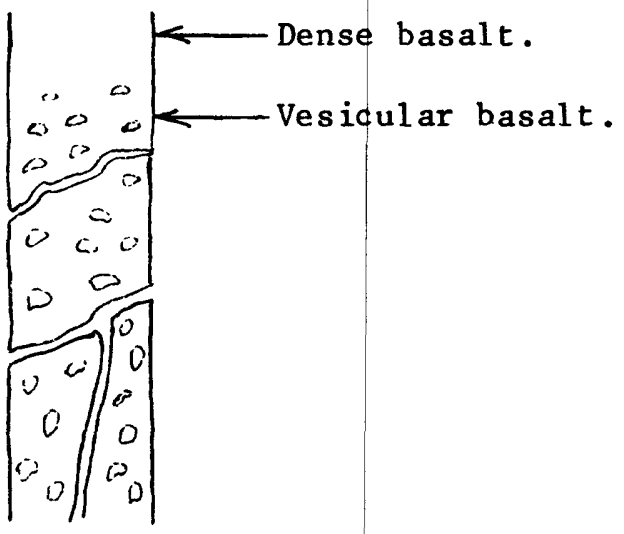

Light-tan material in diagonal fractures at bottom of disrupted core (probably from $66.08 \mathrm{~m}$ ).

Some sedimentary material (10 YR 7.5/3) present, but it is all extremely contaminated with basalt drilling dust. No sample taken.

Curved fracture in dense to slightly vesicular mediumgray basalt.

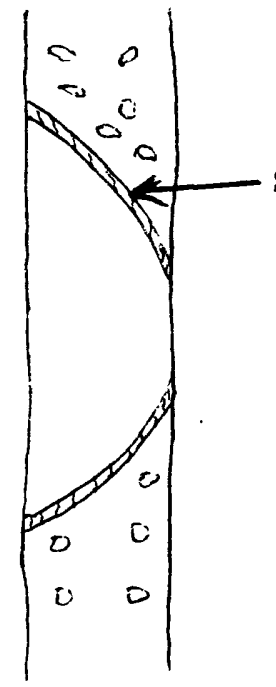
Slightly calcareous (10 YR 7/3).

Top of "73-m sediment bed".

Extremely fractured, slightly vesicular-gray basalt with some sedimentary material fractures.

Fracture filling material immediately above contact between overlying flow and sedimentary interbed (10 YR 7/4). 
$76-6-20$

$70.77-71.08 \mathrm{~m}$

$76-6-21$

$71.54 \mathrm{~m}$

$76-6-22$

$72.02 \mathrm{~m}$

$76-6-24$

$72.02-72.94 \mathrm{~m}$
Brown, fine silty clay (10 YR 5/4).

Non-calcareous.

Brown, fine silt ( 5 YR $5 / 6$ ).

Non-calcareous.

Brown, fine silt (5 YR 4/4).

Red-brown sedimentary material from thin interbed or thick fracture sequence immediately below above sample $(76-6-22)$.

Sedimentary material appears to be filling an array of fractures or voids in vesicular-gray basalt.
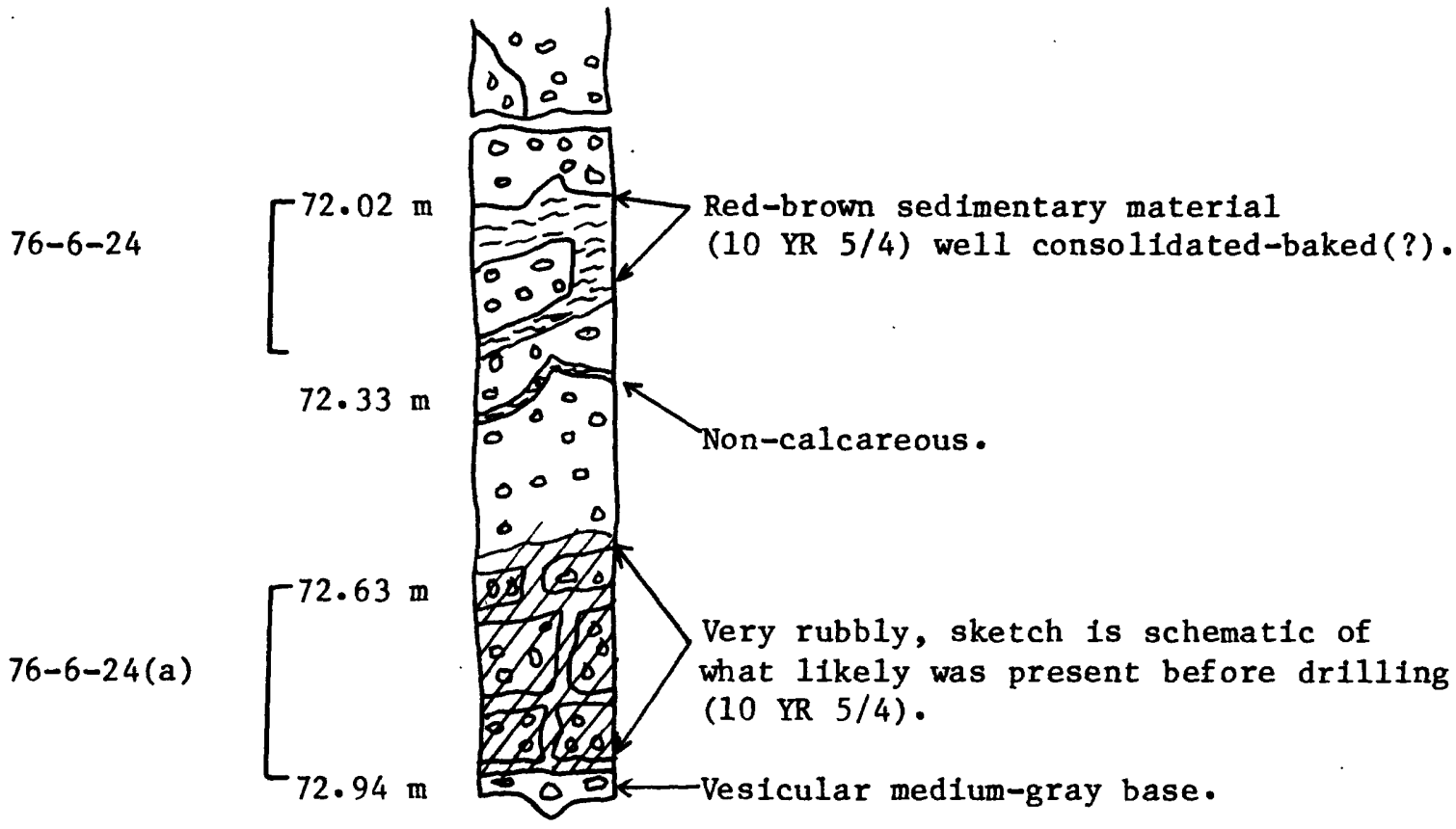
$76-6-23$

$74.01-74.31 \mathrm{~m}$
Vertical fracture filled with light-brown sedimentary material ( 5 YR 7/2) under dense basalt, in vesicular basalt, looks like sedimentary bed below basalt underlying $73 \mathrm{~m}$ interbed.

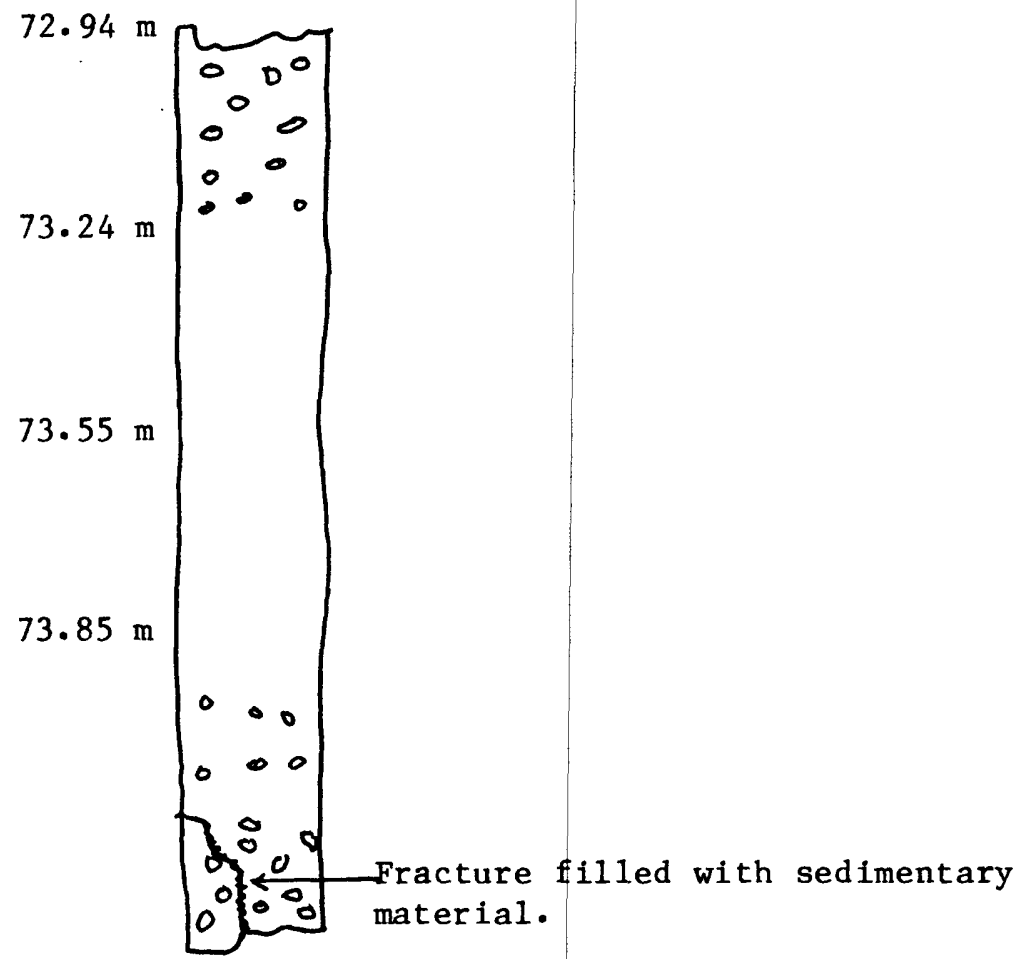


$77-2-1$

$5.33-5.70 \mathrm{~m}$

$77-2-2$

$6.92 \mathrm{~m}$

$77-2-3$

$7.83-8.44 \mathrm{~m}$
Sediment filled fractures (diagonal and horizontal) in medium dark-gray vesicular basalt. Very noncalcareous ( 5 Y $7 / 2$ ).

Vesicles in middle position coated with $\mathrm{CaCO}_{3}$ precipitate.

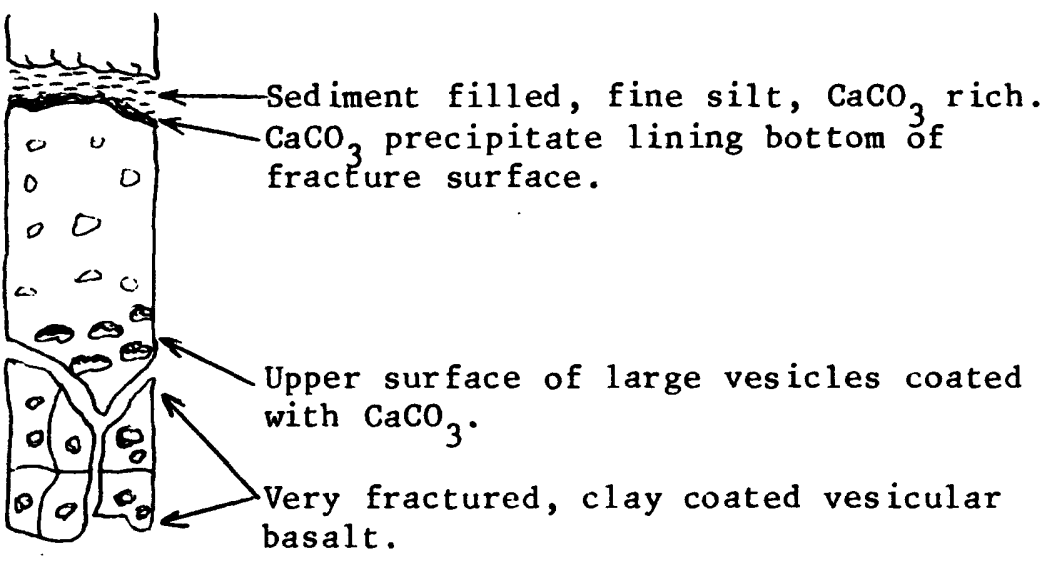

Sediment filled diagonal fracture in medium-gray dense basalt ( 5 Y $7 / 2$ ).

"9-m sediment interbed" equivalent at $8.44 \mathrm{~m}(?)$. Light-brown tan, fine silt ( $5 \mathrm{Y}$ 6/2) fill horizontal, diagonal, and vertical fractures in vesicular mediumgray basalt.

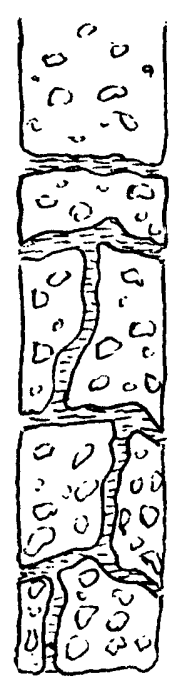

No chemical precipitate in vesicles. No $\mathrm{CaCO}_{3}$ 
$77-2-4$

$9.21 \mathrm{~m}$

$77-2-5$

$11.09 \mathrm{~m}$

$77-2-6$

$11.92-12.01 \mathrm{~m}$
Bottom of "9-m interbed"(?) section between 8.44 and $9.21 \mathrm{~m}$ is missing.

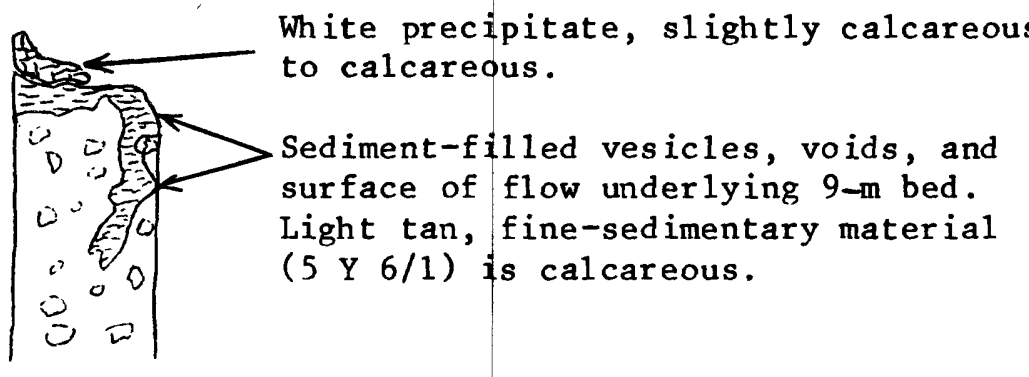

Flow contact(?)--between gray, finely vesicular basalt and coarsely vesicular, red-brown basalt ( 5 Y $7 / 2$ ).

Light-tan clay filling voids between two types of basalt.

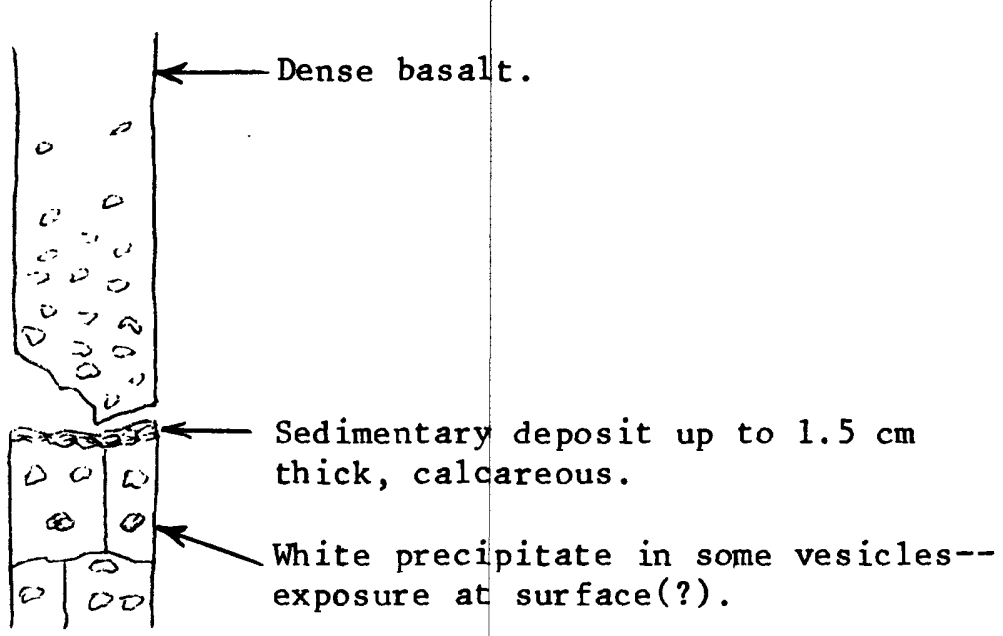

Sediment filled ( 1 ight-tan clay) diagonal fractures ( $5 \times 7 / 2)$ in medium-gray basalt with sparse, large vesicles.

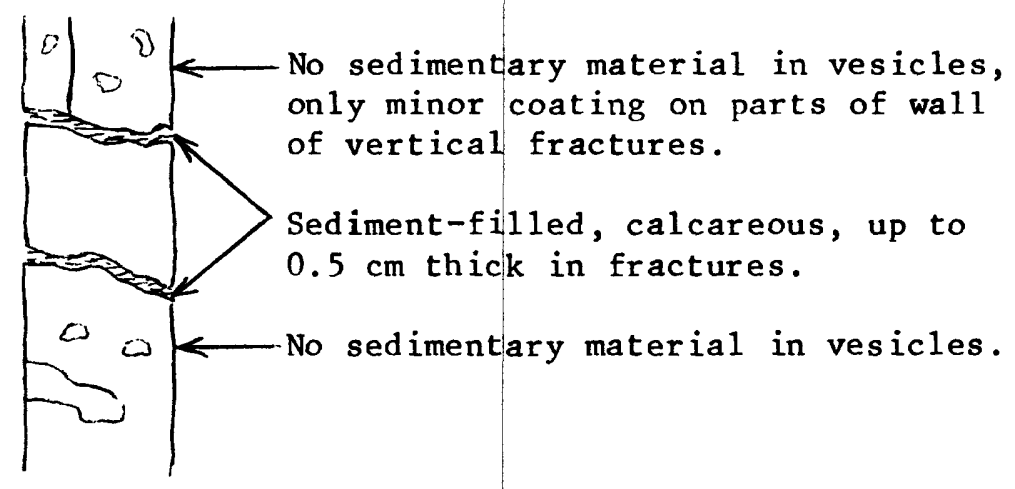


77-2-7

$15.54-15.70 \mathrm{~m}$

$77-2-8$

$16.00-16.46 \mathrm{~m}$
Diagonal fracture, sediment filled $(5 \mathrm{Y} \mathrm{6/2})$ in medium gray slightly vesicular basalt.

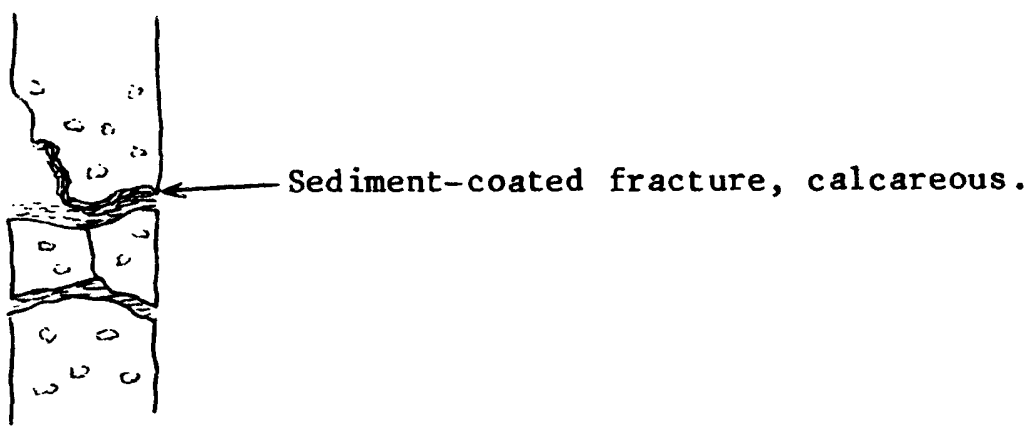

Series of sediment-1ined or filled ( 10 YR 7/3)

diagonal fractures in medium-gray vesicular basalt.

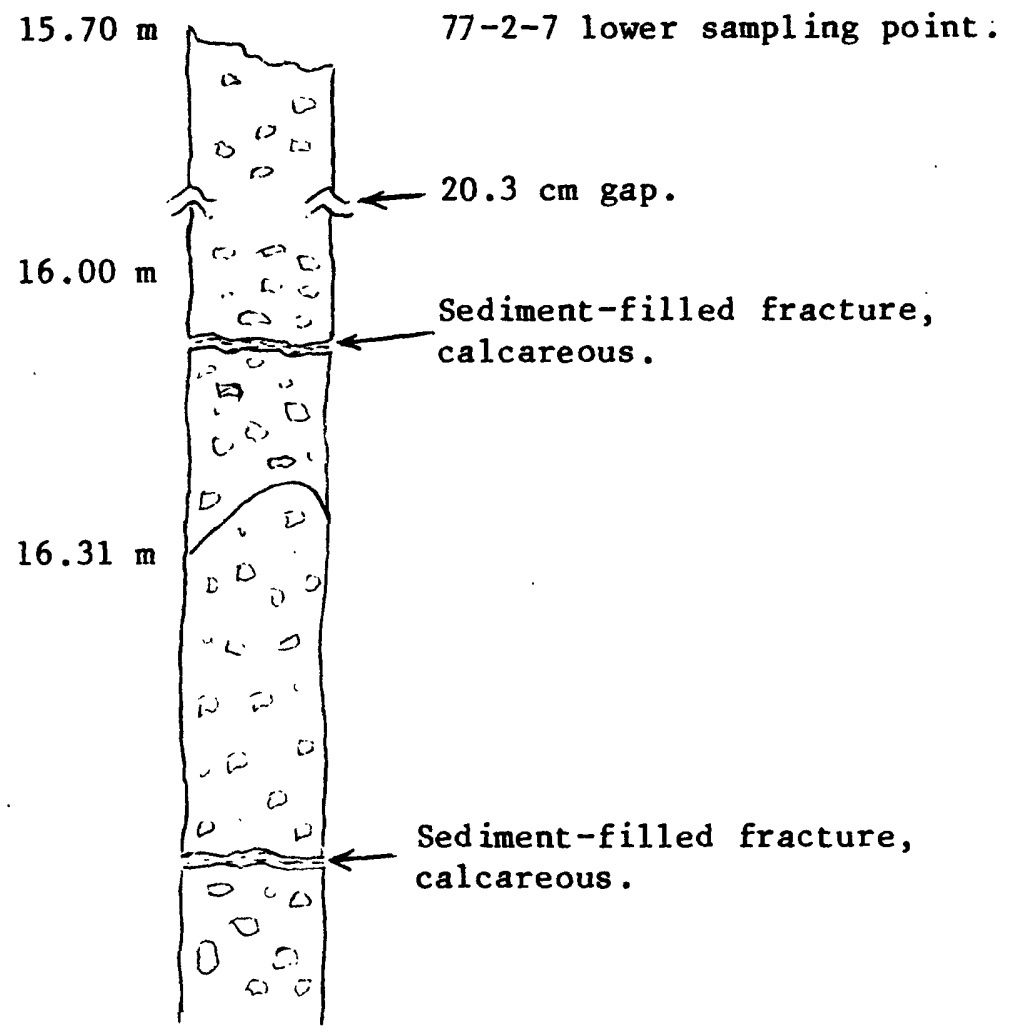


$77-2-9$

$19.02-19.78 \mathrm{~m}$

$77-2-9($ a $)$

$19.02-19.23 \mathrm{~m}$

$77-2-9(b)$
Coated and filled diagonal fractures in dense mediumgray basalt. Upper fractures (19.02 to $19.23 \mathrm{~m} \mathrm{t)}$ are only 1 ined or coated with 1 ight-tan clay. The lower fractures ( 19.54 to $19.78 \mathrm{~m}+$ ) contain sufficient fine silt to fine sand, medium brown, to be filled.

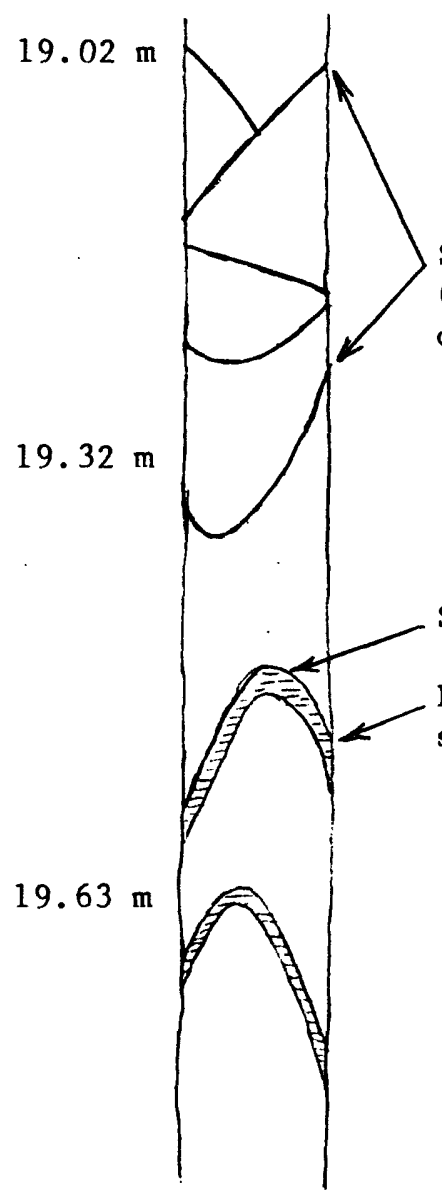

Sl ight 1 y, sed iment-1 ined ( 5 Y $7 / 2$ ) diagonal fractures, calcareous.
Fracture cemented together by sedimentary material. 
$77-2-10$

$20.36-20.79 \mathrm{~m}$

$77-2-10(b)$

$77-2-10(a)$

$77-2-11$

$21.58-21.67 \mathrm{~m}$
Vertical fracture in dense medium-gray basalt filled with up to $1.5 \mathrm{~cm}$ of sedimentary material in two sizes.

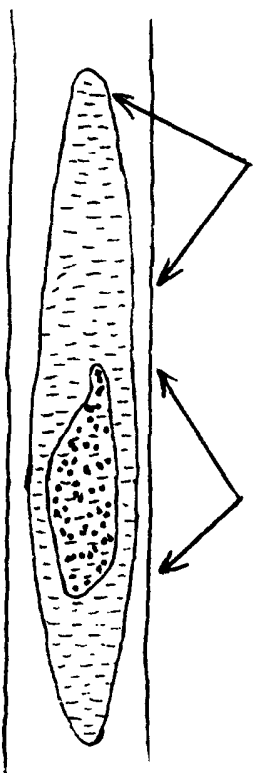

Fine light-tan clay, non-calcareous (10 YR 6.5/3).

Coarser fine sand(?) medium brown, non-calcareous $(5$ Y $6 / 2)$.

Fracture and vesicle filling at beginning of oxidized vesicular basalt.

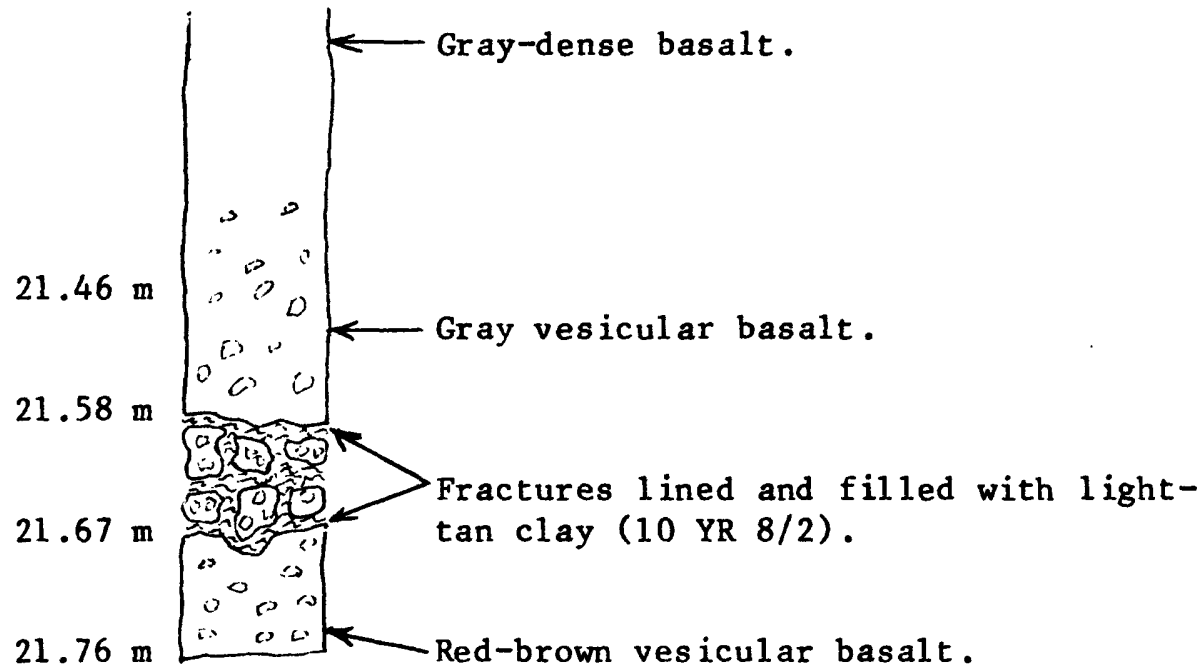

Bottom surface of gray vesicular basalt--showing light-tan clay on top of darker (1ight-medium brown), slightly coarser material (5 Y 6/2).

Evidence of two episodes of fracture filling. 
$77-2-12$

$21.98-22.07 \mathrm{~m}$

$77-2-13$

$23.29 \mathrm{~m}$

$77-2-14$

$26.12 \mathrm{~m}$

$77-2-15$

$26.33-26.64 \mathrm{~m}$
Series of diagonal fractures in red-brown coarsely vesicular basalt. Some fractures, the wider ones(?), filled with sedimentary material. Narrower ones only clay coated.

$22.07 \mathrm{~m}$

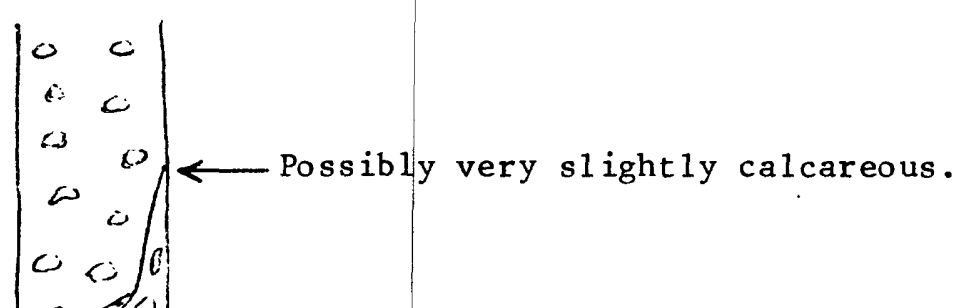

$21.98 \mathrm{~m}$

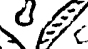

$\therefore 0$ i 6
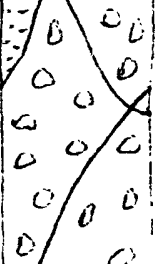

c.

$\int \mathrm{c}$

Clay and fine silt filled diagonal fracture in red-brown vesicular basalt (10 YR 6/3). Clay on upper surface.

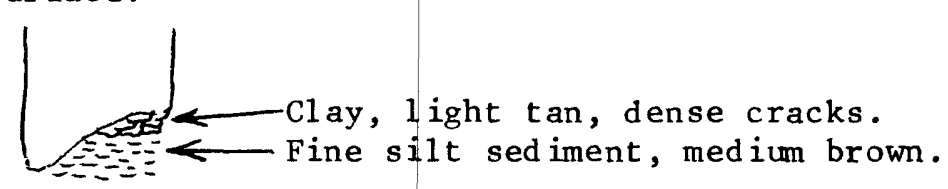

Water producing. zone, horizontal and diagonal fractured dense medium-gray basalt ( 5 Y $7 / 2$ ).

$26.33 \mathrm{~m}$

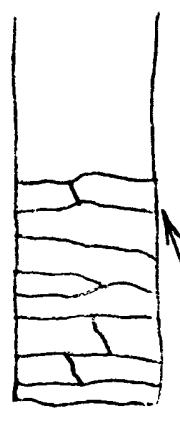

Minimal clay coatings on any of

$26.03 \mathrm{~m}$ the fracture surfaces except void

$26.33 \mathrm{~m}$

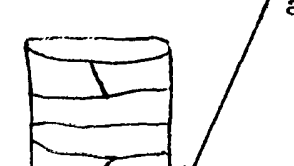
at $26.64 \mathrm{~m}$.

$26.64 \mathrm{~m}$

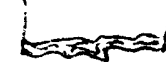

Clay-lined surface of void (5 Y 7.5/3). 


\section{THIN-SECTION ANALYSES}

Thin-section analyses of samples from the 1976-1977 drilling program were made to determine significant sedimentary characteristics. In addition to cored. samples, surficial sedimentary samples were collected to attempt better characterization of the surficial sedimentary material and to relate this characterization to those observed in the sedimentary interbeds. Sedimentary samples were also obtained from trenches excavated beneath pit 2 (see fig. 2), which was utilized from 1959 through 1963 for the burial of transuranic waste. These samples are designated EWR samples for their locations beneath Early Waste Retrieval (EWR) pits.

Thin-section observations and those made utilizing scanning electron microscropy are presented in the following section.

WELL $76-1$

Sample 76-1-1 taken at $26.21 \mathrm{~m}$ shows a sediment-basalt contact in a fracture (fig. 3). This sequence starts with unaltered basalt. The first sedimentary layer may be a zone of basalt alteration up to $60 \mu \mathrm{m}$ thick. It contains small, diameters up to $12 \mu \mathrm{m}$, opaque mineral grains not observed in the overlying thicker clay layer and is bounded on the sedimentary side in some places by an iron-oxyhydroxide band up to $36 \mu \mathrm{m}$ thick. The second sedimentary layer is a series of layers of clay up to $550 \mu \mathrm{m}$ thick. The clay shows evidence of compaction and desiccation. Because most of the desiccation fractures are continuous into the overlying coarser material and show no infilling by the coarser material, it is believed that the fracturing occurred after coring. The desiccation fractures do not penetrate the zone of basalt alteration but turn parallel to it. This may be a function of "armoring" by the iron-oxyhydroxide layer.

Sand fracture-filling material appears to have been introduced in at least two events. The first sand fill consists of poorly sorted quartz sand grains, up to $100 \mu \mathrm{m}$ in diameter, in a fine silt-clay matrix. Some of the elongated grains show orientation with long axis parallel to fracture 
surface. The second sand fill has a much larger average grain size but the maximum grain size is only $120 \mu \mathrm{m}$. The matrix is a clay-silt material.

Secondary amorphous silica is observed as partial vesicle filling and complete vesicle lining (76-1-1 at $27.83 \mathrm{~m}$ ). The silica structure has grown away from a point on the wall of the vesicle with no obvious route for solution migration. The bottom of the vesicle also contains layered amorphous silica. Some vesicles in the same thin section are filled with layered silica. All of these samples (76-1-2(a), $-2(b)$, and $-2(c)$ ) were collected from vesicles in the flow which in other nearby wells is overlain by the 34-m sedimentary interbed. No chemical precipitants are observed in vesicles of the shallowest flow in this sequence suggesting that the flow was not exposed long enough under climatic conditions conducive to the development of alteration products similar to those associated with the 34-m interbed.

Additional observations in the same sequence include the replacement of secondary silica by later-stage secondary carbonate (76-1-3(b) - figure 4, and white precipitation in 76-1-4(b) and 76-1-4). C1ay-coated grains observed in section 76-1-4(a) from a sand-filled fracture show secondary silica coating the clay coated quartz grain. This silica coating occurred following the emplacement of the sand in the fracture as evidenced by the discontinuity of the silica coatings where clay-size material is present as matrix material in the sand. Interlayering of silica and carbonate observed in 76-1-4 suggests either selective replacement or a sequential deposition which would require alteration in water chemistry. The former hypothesis is more plausible.

Samples identified as 76-1-4 show a thick (up to $1 \mathrm{~cm}$ ) layered silica and carbonate precipitate on the upper surface of sand-filled voids. There is no evidence of clay lining the bottom surface of the void. C1ay is observed overlying the sand and coating a vertical fracture which cuts the sand and the underlying basalt.

$X-r a y$ analysis of a sample of stalactitic vesicle filling material $(76-1-6 c)$ at a depth of $29.02 \mathrm{~m}$ indicates poorly crystalline cristobalite 


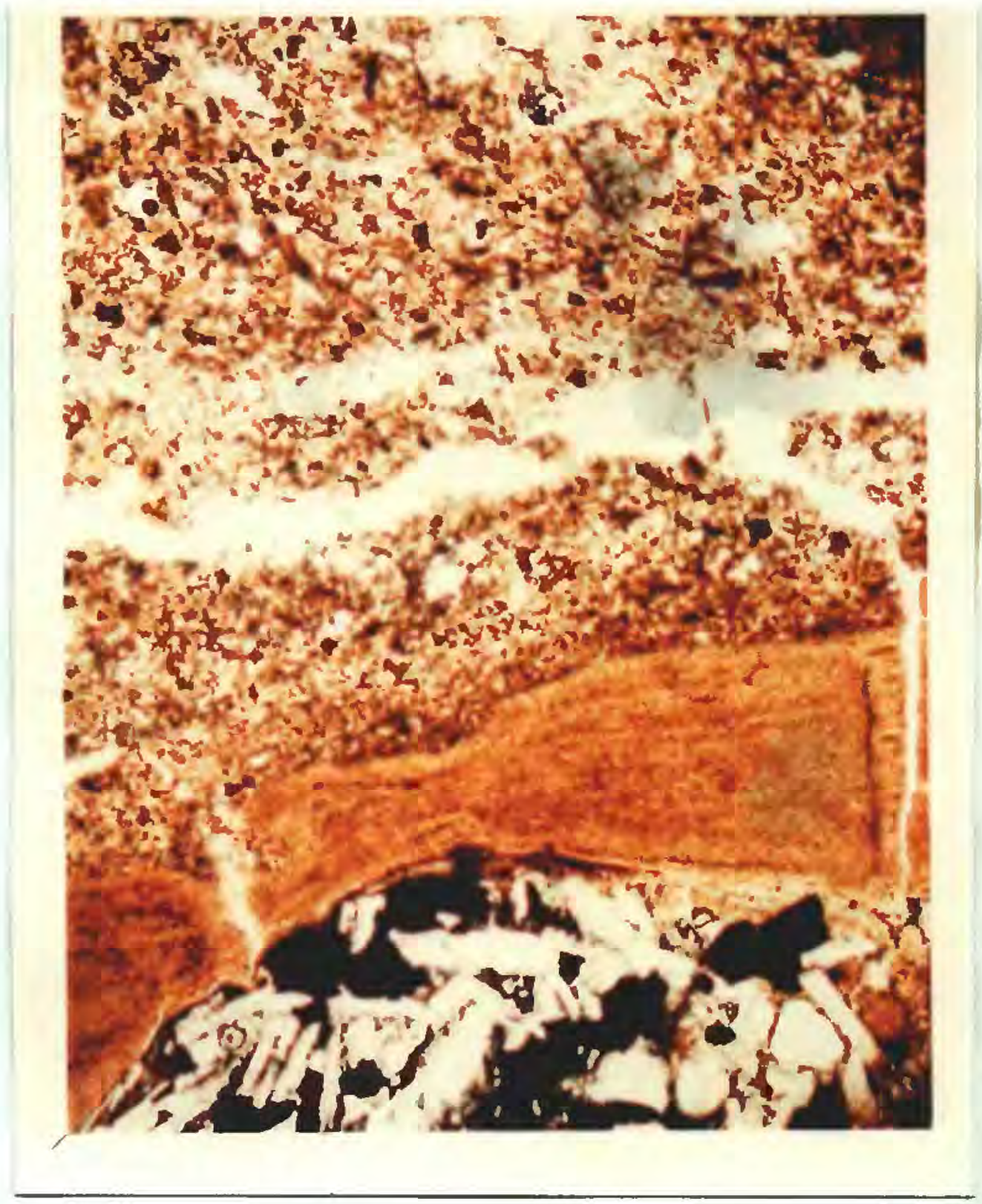

Figure 3.--Photograph of a thin section from sample 76-1-1, showing a basalt-sedimentary contact in a fracture located at $26.21 \mathrm{~m}$ in well 76-1. 


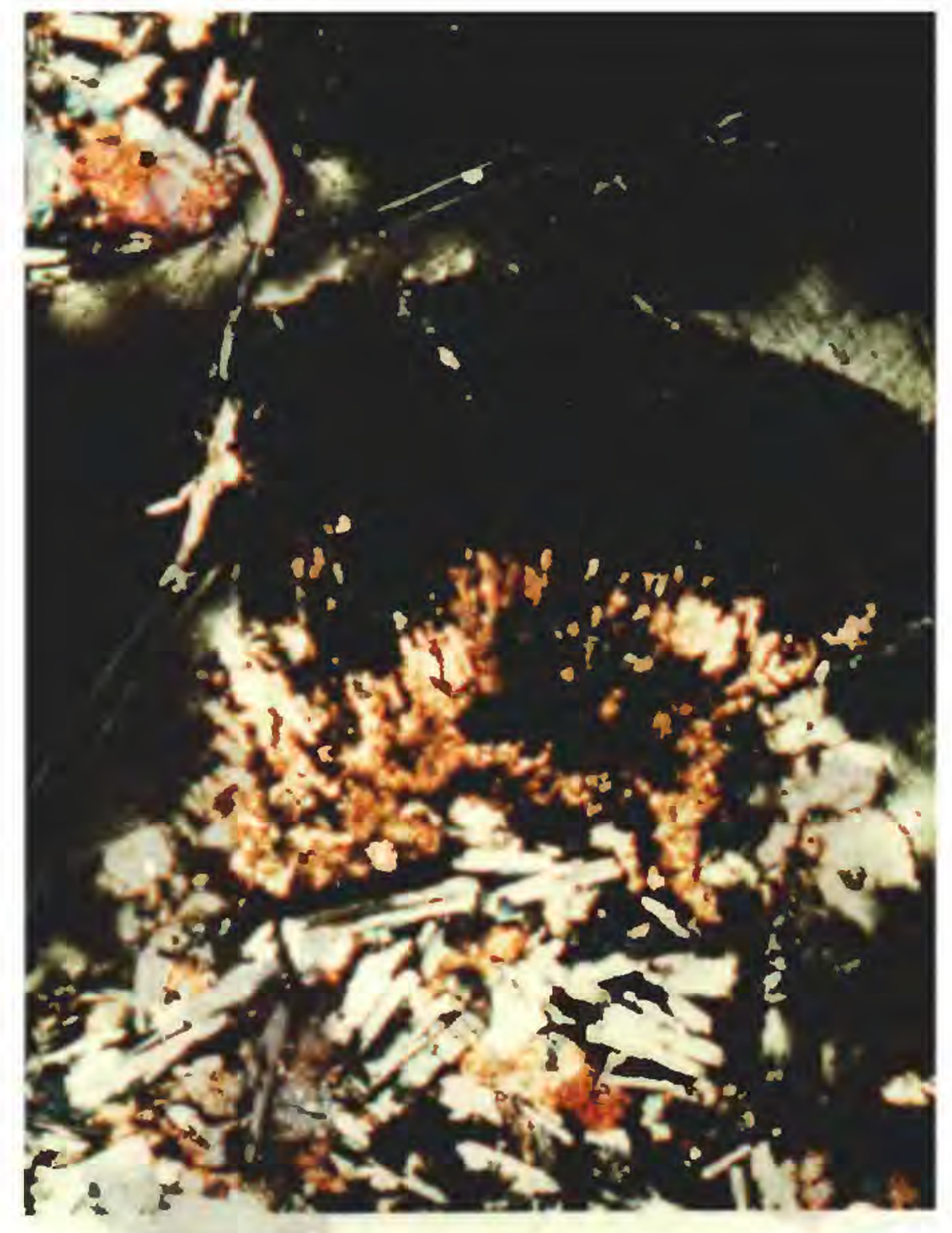

Figure 4.--Photograph of a thin section from sample 76-1-3(b), showing replacement of secondary silica by laterstage secondary carbonate. 
(approximately 90 percent) with some calcite, a little feldspar, and very little quartz.

WELL 76-2

Thin section 76-2-4, from a depth of $8.05 \mathrm{~m}$ in well $76-2$, shows the presence of amorphous silica within a fracture immediately below the 9-m sedimentary interbed. A thin section of sample 76-2-5(a), from a depth of $9.11 \mathrm{~m}$ in the same wel1, shows carbonate stalactites with a fibrous or radiating fabric of groups of crystals.

WELL 76-3

A sequence of sediment-basalt and sediment-sediment relationships observed in a fracture in sample 76-3-11(b) (fig. 5), from a depth of $25.15 \mathrm{~m}$, shows what appears to be cross-bedded clay material deposited on a fracture surface in the basalt. This surface shows some evidence of alteration (fig. 6); i.e., small opaque particles in a discontinuous layer within the clay.

The clay layer is overlain by a layer of slightly coarser ( 2 to $3 \mu \mathrm{m}$ ) material, which in turn is overlain by a fracture filling unit of sand particles up to $180 \mu \mathrm{m}$ in a matrix of 2 to $3 \mu \mathrm{m}$ material. The entire sequence is in excess of $1.5 \mathrm{~mm}$ thick and indicates at least three recharge episodes of increasing intensity.

Thin section 76-3-22(b), at $38.28 \mathrm{~m}$, shows vividly the permeability of the basalt flows to fluids. Large calcite crystals are observed overlying sedimentary layers in most voids in the basalt. Some vesicles containing no sediment are filled with calcite crystals up to 625 by $47 \mu \mathrm{m}$. Similar large calcite crystals have been observed previously only in well 93A. In that well a one centimeter-wide fracture was encountered that has been filled with cement from adjacent well 93. It is felt that the large calcite crystals observed in this thin section and in the core (we11 76-3) is also 


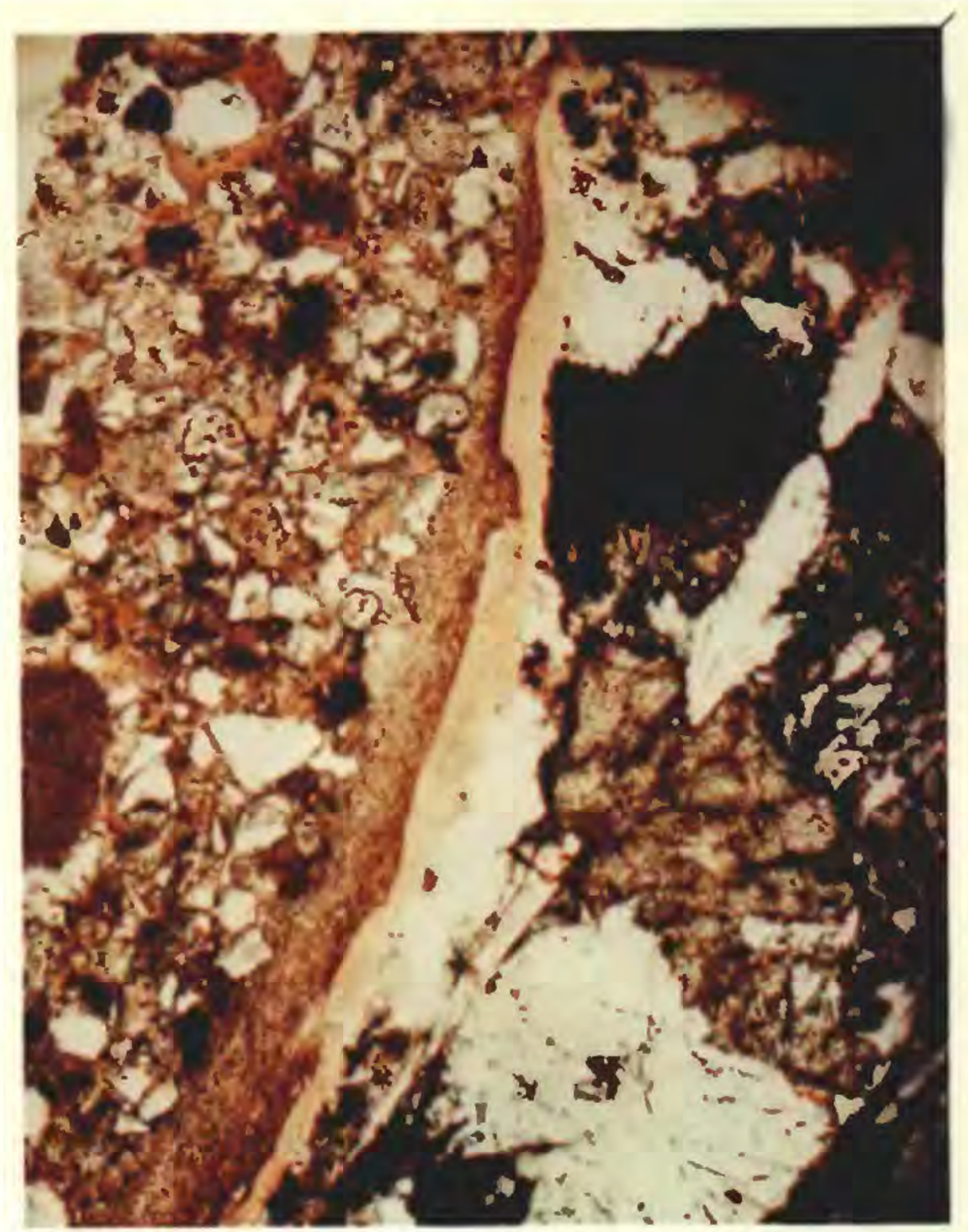

Figure 5.--Photograph of a thin section from sample 76-311(b), showing cross-bedded(?) clay material in a fracture located at $25.15 \mathrm{~m}$ in well 76-3. 


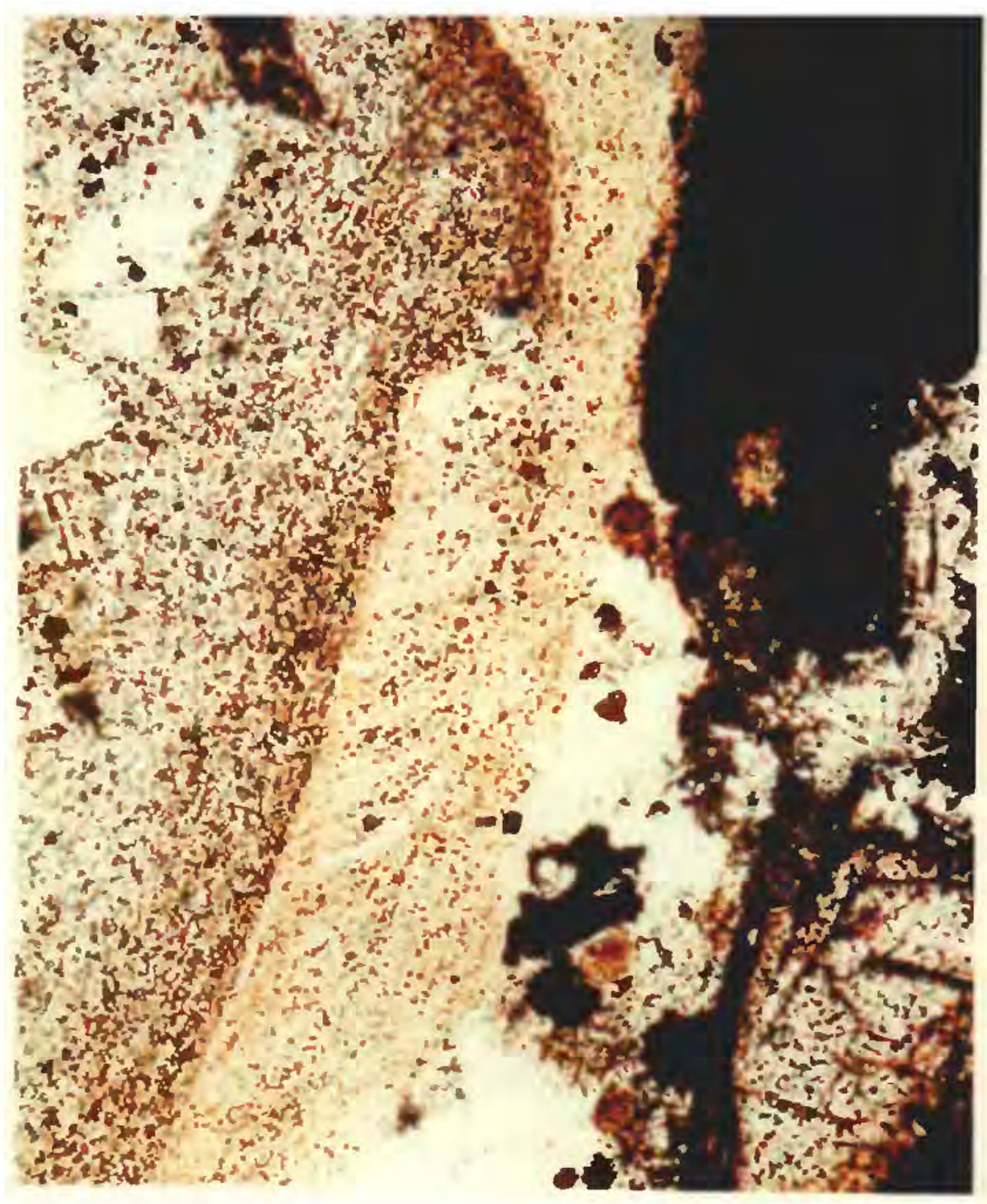

Figure 6.--Photograph of a portion of the thin section shown in figure 5, showing small opaque particles within the clay. 
and 76-4A were in a topographic low where water could collect. Sample 76-4-12(f) shows what appears to be the replacement of a lath-like mineral by carbonate. The most prominent lath-shaped mineral in the system is plagioclase feldspar, suggesting the possibility of carbonate replacement of basalt minerals. The sediment-basalt contact in this section is diffuse suggesting the possibility of alteration.

EWR SUBPIT SAMPLES

Examination of a thin section collected from beneath the surficial sedimentary material in the EWR subpit sampling showed several cycles of $\mathrm{CaCO}_{3}$ precipitation. Thin section SP-2 shows at least five layers, the dominant one being a thick ( $1 \mathrm{~mm}$ ) layer of radiating $\mathrm{CaCO}_{3}$ crystals. This is underlain and overlain by layers of drusy $\mathrm{CaCO}_{3}$. Thin section Surf-1 of a basalt currently exposed on the surface shows vesicle fillings with approximately 15 layers of $\mathrm{CaCO}_{3}$ in a $900 \mu \mathrm{m}$ thick section. The thickness of individual layers and the size of the calcite crystals must depend on the availability of moisture. The age of the flow in which this carbonate development is observed is estimated at less than 200,000 years by Kuntz and others (1980).

SCANNING ELECTRON MICROSCOPY

Scanning electron microscopy (SEM) analyses were conducted in an attempt to ascertain the mineralogic and chemical composition of selected samples, particularly those from vesicles underlying the basalt flow contact where the $34-m$ sedimentary interbed is missing. X-ray mineralogic determinations were carried out to verify mineralogic determination made utilizing the SEM.

A very brief description for each sample follows:

$76-1-3(c)$

$27.92-28.13 \mathrm{~m}$.

Mineralization in vesicles (chemical precipitate). SEM - Homogeneous clay 
$76-1-3(c)$ $27.92-28.13 \mathrm{~m}$.

$76-1-4(c)$

$28.22 \mathrm{~m}$

$76-1-6(c)$

$29.00 \mathrm{~m}$
$\mathrm{X}$-ray - Clay and feldspar are the major minerals present. The feldspar is bytownite(?), the clay is a mixed layer but has clearly evident peaks for 7,10 , and $15 \mathrm{~A}$, quartz is minimal.

White precipitate on wall of vesicle.

SEM - The dominant mineral is smectite with abundant mobile silica and minimal aluminum in system. Large plates with plately texture at $30 \mathrm{~m}$. Small, lightcolored crystals on surface of plates are calcite.

$\mathrm{X}$-ray - Clay minerals $>$ quartz > feldspar. Well developed clay peaks on whole rock diffraction trace. Sample about 60 percent clay mineral. The feldspar present is albite.

White precipitate on the upper fracture surface. SEM - Large clay platelets (smectite) surrounded by calcite crystals (fig. 7). Calcite crystals on surface of clay plates. Energy Dispersive X-ray Analysis (EDXA) shows smectite is calcium-rich. $\mathrm{X}$-ray - Calcite $>$ quartz $>$ clay $>$ feldspar. The clay
almost completely mixed layer illite/smectite. The feldspar is highly weathered making identification difficult.

White stalactitic growth.

SEM - Smectite, or calcite plus clay (fig. 8). One point on sample analysed by EDXA showed very high iron aluminum silicate and may contain nontronite or iron oxide plus clay. Small light crystals on smectite surface are calcite.

$X$-ray - approximately 90 percent of precipitate material is poorly cry\$talline cristobalite. Some calcite, feldspar and yery little quartz. Clay minerals present are smectite and mixed-layer clays. 


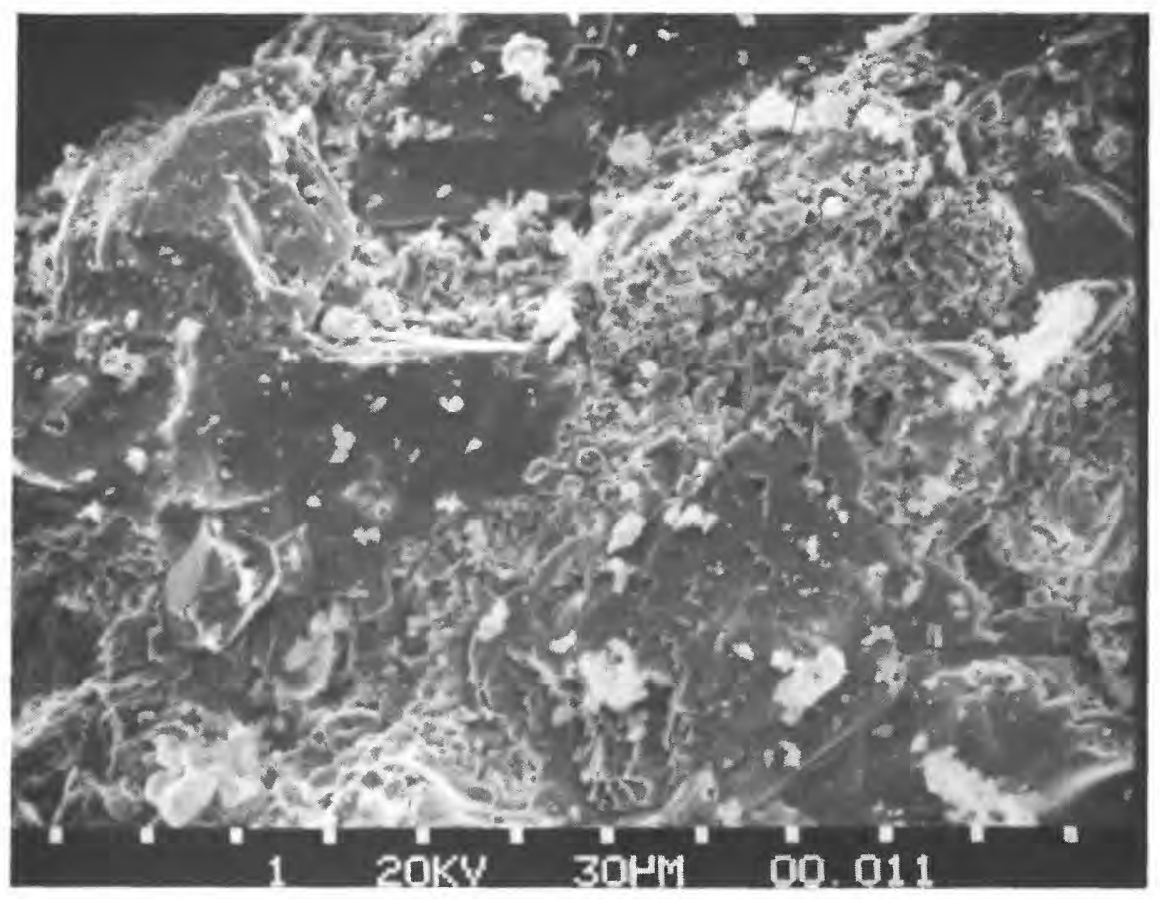

Figure 7.--SEM photograph of sample 76-1-4(c), showing clay platelets (smectite) surrounded by calcite crystals on the upper surface of a fracture located at $28.22 \mathrm{~m}$ in well $76-1$.

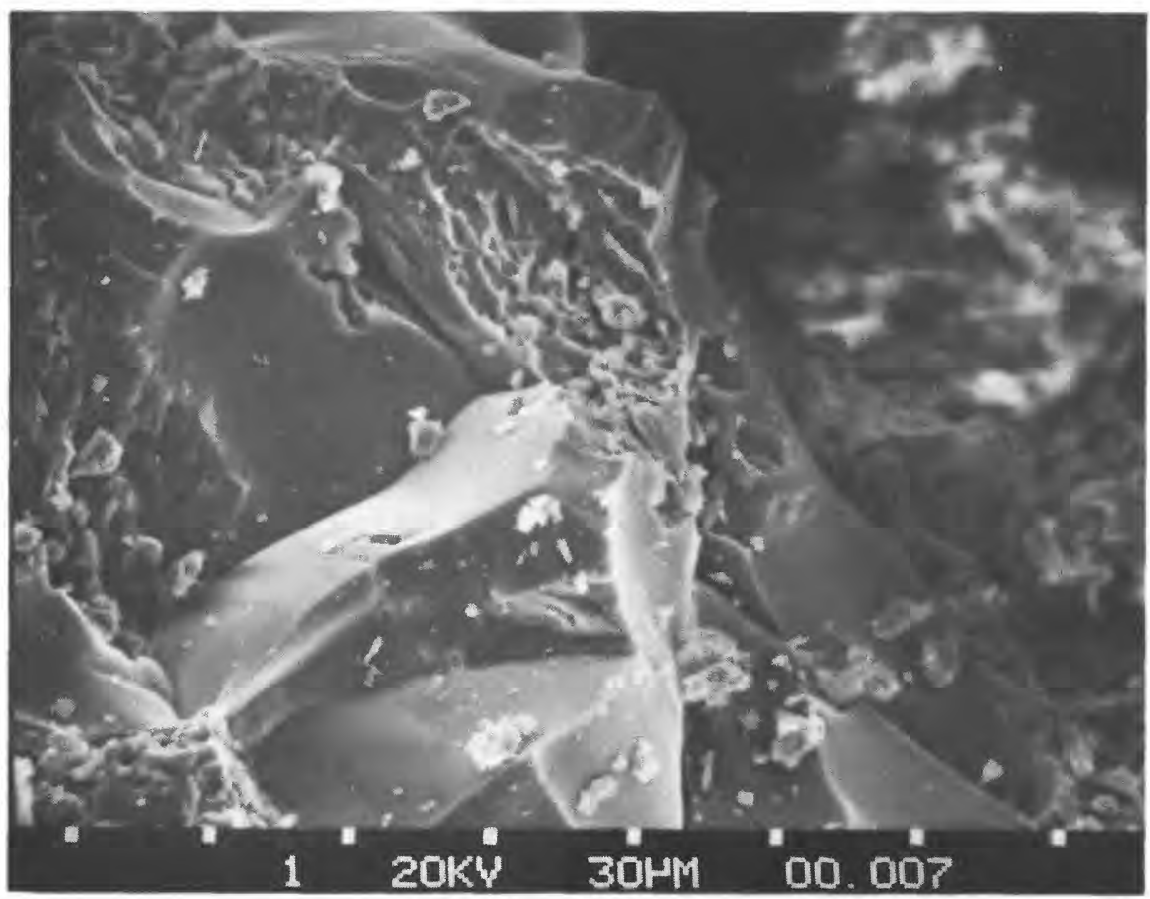

Figure 8.--SEM photograph of sample 76-1-6(c), showing a white stalactitic growth, composed of smectite or calcite plus clay, at $29.00 \mathrm{~m}$ in well 76-1. 
$76-4-12$

$29.93 \mathrm{~m}$

$93 \mathrm{~A}-1 \mathrm{~B}-1$

$7.41 \mathrm{~m}$

$93 A-1 B-2$
Thin highly calcareous caliche unit underlying the thin $34-m$ sedimentary interbed. Samples of carbonate.

SEM - There is much clay mixed in with the carbonate.

Calcium is approximately equal to silica in the clay system.

$\mathrm{X}$-ray - The vesicle filling contains primarily wellcrystallized calcite with mixed layer clays. Minor amounts of albite and quaftz are present.

Calcite and clay lined fracture.

SEM - Clay being altered, possibly to zeolite (heulandite? or clinoptilolite?). The blade is calcium silicate, low in iron and magnesium (plagioclase?). The the right of the blade is a smectite, a calcium aluminum silicate (fig. 9)

X-ray - Analysis shows presence of mixed layer clays, possibly chlorite and chabazite, mixed feldspars and quartz.

SEM - Clay platelet on top of small crystals. The small crystals are bladed with a random orientation. Possibly clinoptilolite (fig. 10).

These analyses indicate that in addition to detrital clay minerals, (quartz, feldspar, etc.) there are some authigenic clay minerals, possibly some zeolites, also cristobalite, and abundant calcite form in place within the basalt and sedimentary layers in the RWMC area.

\section{ANALYTICAL PROCEDURES}

Samples of rain and snow were collected for chemical and isotopic analyses to provide background information on the principal input to the system. Selected samples have been analyzed for deuterium and oxygen-18 content. X-ray mineralogic analyses were conducted on surficial sediment, 


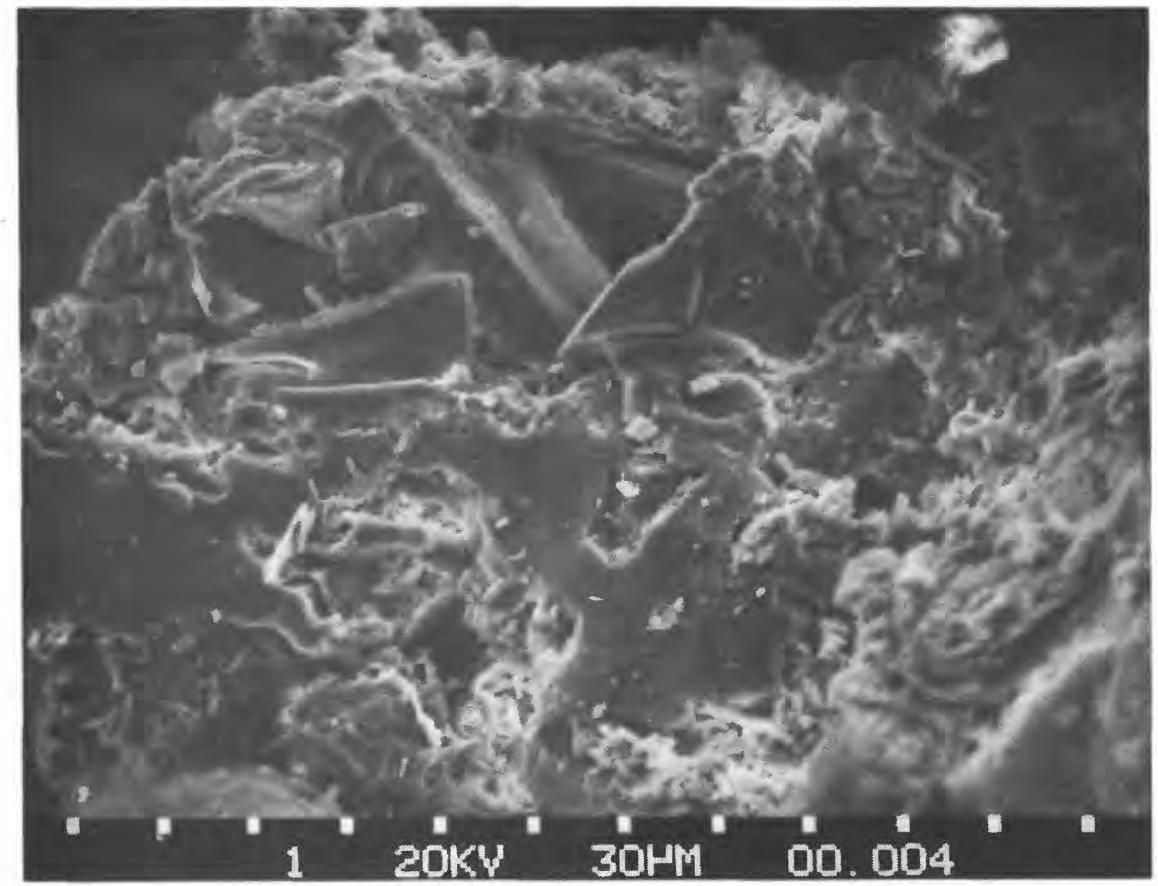

Figure 9.--SEM photograph of sample 93A-1B-1, showing calcite and clay material lining a fracture at $7.41 \mathrm{~m}$ in well $93 \mathrm{~A}$.

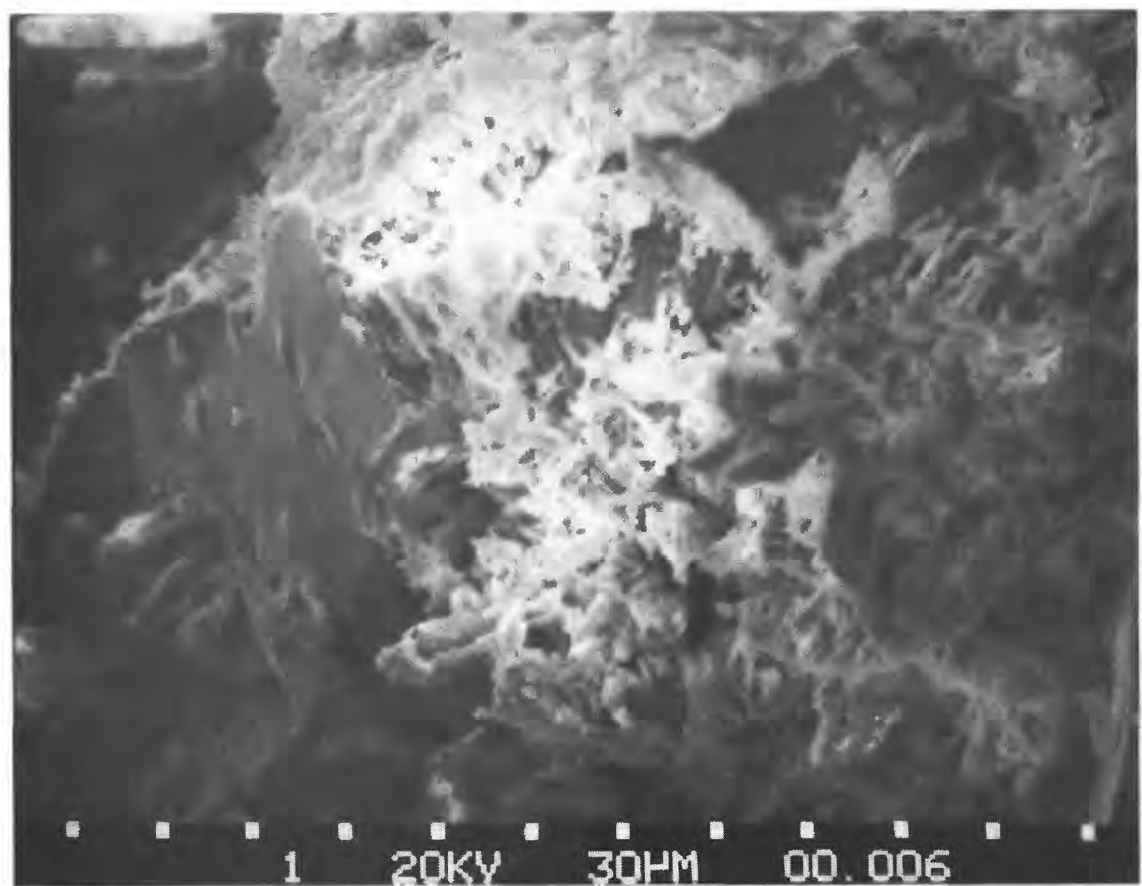

Figure 10.--SEM photograph of sample 93A-1B-2, showing a clay platelet on top of small crystals from the same sampling locality as depicted in figure 9. 
interflow sediment, and fracture filling sedimentary material to facilitate the determination of sediment origin. Carbonate content and carbon and oxygen-isotope ratios of the calcium carbonate in sedimentary material were determined to help ascertain sedimentary surface stability and age. Sample preparation and analytical techniques are detailed in the following section.

The analysis of stable isotope content of the various components in natural systems contributes significantly in determining what chemical reactions or physical processes have occurred and to what extent these processes have approached completion. Isotopic data should be considered as one tool to be used in conjunction with hydfologic, mineralogic, and chemical data to aid in the interpretation of complex hydrogeochemical problems. No attempt will be made here to explain all the intricacies of stable isotope geochemistry; however, because results of this study relied significantly on isotopic evidence, it is desirable to present a brief introduction to the subject to familiarize the uninitiated.

Carbon, oxygen, and hydrogen are found in the natural environment distributed among several naturally occurring isotopes. Carbon has two stable isotopes carbon-13 $\left({ }^{13} \mathrm{C}\right)$ and carbon-12 $\left({ }^{12} \mathrm{C}\right)$ with an average abundance of 1.11 and 98.89 percent, respectively. The ${ }^{12} \mathrm{C} /{ }^{13} \mathrm{C}$ ratio in meteoric and terrestrial materials ranges from 88 to 94 percent.

Oxygen occurs as three stable isotopes, oxygen-16 ( $\left.{ }^{16} 0\right)$, oxygen-17 $\left({ }^{17} 0\right)$, and oxygen-18 $\left({ }^{18} 0\right)$ with a natural abundance in ocean water of $99.763,0.0372$, and 0.1995 percent, respectively. The ${ }^{18} 0 /{ }^{16} 0$ ratio exhibits a total variation of 10 percent in nature.

Hydrogen occurs as stable isotopes of hydrogen (H) and deuterium (D) in a natural abundance of 99.984 percent and 0.016 percent. 
STANDARDS AND $\delta$ NOTATION

In geochemical studies the absolute ratios of the isotopes are generally not discussed, a more convenient notation being the differences in those ratios. Because of this, geoscientists normally report isotopic differences in the $\delta$ (delta) notation. The value in per mil or parts per thousand $(\%)$ reports the ratio of a sample relative to that of a known standard. The value is defined as:

$$
\delta_{\mathrm{SPL}}(\%)=\frac{\mathrm{R}_{\mathrm{SPL}}-\mathrm{R}_{\mathrm{STD}}}{\mathrm{R}_{\mathrm{STD}}} \times 10^{3}
$$

where $\mathrm{R}_{\mathrm{SPL}}$ is the ratio of $\mathrm{D} / \mathrm{H},{ }^{18} \mathrm{O} /{ }^{16} \mathrm{o}$, or ${ }^{13} \mathrm{C} /{ }^{12} \mathrm{C}$ for the sample and $\mathrm{R}_{\mathrm{STD}}$ is the corresponding ratio for a known standard. The ratio is always that of the heavy isotope to the light isotope. A positive number indicates that the sample is enriched in the heavy isotope relative to the standard, while a negative number indicates that the sample is depleted in the heavy isotope relative to the standard. The value is what is actually measured by an isotope ratio mass spectrometer.

The standards most commonly used for reporting stable isotope data are supplied by the U.S. National Bureau of Standards and the International Atomic Energy Agency (IAEA, Vienna, Austria). There are two internationally accepted standards for reporting oxygen-isotope contents. The PDG (Pee Dee Belemnite) standard, which was the working standard of the University of Chicago Laboratory at the time the oxygen paleotemperature scale was developed, is normally used only for ocean paleotemperature studies. The SMOW (Standard Mean Ocean Water) standard was defined by Craig (1961a) in terms of an NBS reference water, NBS-1. Since then IAEA-Vienna has prepared a large quantity of water which they distribute as SMOW.

Intercomparison by many laboratories shows that the oxygen isotope composition of this standard agrees with that defined by Craig (1961a) within the limits of analytical uncertainty $( \pm 0.5 \%$ 
The SMOW standard is used for reporting hydrogen isotope compositions also and was defined by Craig (1961b) relative to NBS-1. IAEA water distributed as SMOW has been found to be depleted in deuterium by $1.2 \%$ (relative to Craig's (1961b) defined standard (Coplen and Clayton, 1973)). Most laboratories do not quote precision greater than $1.5 \%$ so this difference may not be serious.

The internationally accepted carbon standard is the PDB standard which is no longer available. Carbon-isotope samples are generally run against laboratory standards which are calibrated against two reference standards distributed by U.S. National Bureau of Standards NBS-20 (Solenhofen limestone) and NBS-21 (spectrographic graphite). The analytical data is then reported relative to $\mathrm{PDB}$ for ease of comparison with earlier data.

\section{FRACTIONATION FACTORS}

Fractionation discussed in isotope studies is the differentiation of a mixture by the separation of components in any mass-transfer process. Fractionation of isotopes is on the basis of slight difference in molecular mass. In general terms both physical and chemical processes can lead to isotopic fractionation with the heavier isotope remaining in the condensed phase and the lighter isotope favoring the more volatile phase.

A fractionation factor under equilibrium conditions is related to a chemical equilibrium constant, $K$, in that it tells the isotopic fractionation that one should expect between two related phases under isotopic equilibrium conditions. The isotope fractionation factor between substances $A$ and $B$ is defined as:

$$
\alpha_{A-B}=\frac{R_{A}}{R_{B}} \text {. }
$$

If isotopes are randomly distributed over all possible bonding sites in species $A$ and $B$, the fractionation factor $(\alpha)$ is related to the chemical 
equilibrium constant, $K$, for isotope exchange reactions in the following way:

$$
\alpha=\mathrm{K}^{1 / \mathrm{n}} \text {, }
$$

where $\mathrm{n}$ is the number of atoms exchanged. For the isotope exchange reaction of oxygen in $\mathrm{CO}_{2}$ to oxygen in water vapor.

$$
\begin{aligned}
& { }_{1 / 2} \mathrm{C}^{16} \mathrm{O}_{2}+\mathrm{H}_{2}{ }^{18} \mathrm{o}_{<--}^{->} \mathrm{b}_{2} \mathrm{C}^{18} \mathrm{o}_{2}+\mathrm{H}_{2}{ }^{16} \mathrm{O}, \\
& \mathrm{K}=\frac{\left(\mathrm{C}^{18} \mathrm{O}_{2}\right)^{3 / 2}}{\left(\mathrm{c}^{16} \mathrm{O}_{2}\right)^{3 / 2}} \cdot \frac{\left(\mathrm{H}_{2}{ }^{16} \mathrm{O}\right)}{\left(\mathrm{H}_{2}{ }^{18} \mathrm{O}\right)}
\end{aligned}
$$

The equilibrium constants for these reactions are equal to the fractionation factor:

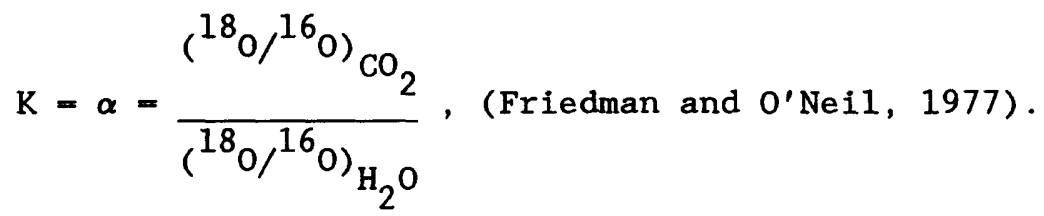

NATURAL FRACTIONATION

Isotope fractionation may be caused by physical processes (evaporation), chemical processes (mineral precipitation, redox reactions) or biological processes ( $\mathrm{CO}_{2}$ fixation during photosynthesis). Generally, it is safe to say that during a physical or chemical process the molecule enriched in the heavier isotope tends to remain in or enter the more condensed phase. If we look at the evaporation process with a limited water reservoir and evaporate the water, the water molecules depleted in either ${ }^{18} \mathrm{O}$ or $\mathrm{D}$ will escape across the air-water interface more easily. If we keep removing the water vapor so as not to attain saturation, the residual water will become more and more enriched in the heavy molecules until evaporation is completed. If we use an infinite reservoir like the ocean, the enrichment 
in the residual water will not be significant, but an equilibrium fractionation will exist between the ocean and the water vapor.

This fractional is observed in reverse in the condensation of water vapor from the atmosphere as rain. Once the air mass containing the water vapor leaves the ocean and starts moving across a land mass, conditions conducive to condensation and precipitation will occur. In this case the heavier molecules will tend to condense first leaving moisture in the air mass even more depleted in the heavy isotopes. In a gross simplification, the moisture precipitating furthest from the source and at the coldest temperature will be the most depleted in heavy isotopes.

It must be emphasized that isotope fractionation factors, like chemical equilibrium constants, are very dependent on temperature. This is what permits the utilization of isotopes as paleotemperature indicators.

Friedman and O'Neil (1977) have published a compendium of available fractionation factors which are of geochemical interest. The fractionation factors used in this study are from this source, unless noted otherwise.

In addition to the fractionation process which is used to explain the stable isotope values observed in precipitation and ground-water samples, the relationship of oxygen in waters to oxygen in minerals formed in equilibrium with these waters must be considered. When $\mathrm{CaCO}_{3}$ precipitates from water under isotopic equilibrium conditions at 6 oC ( 279 oK), the average temperature of ground water at the INEL, the fractionation factor is 1.03279 or $32.79 \%$. Then, if the oxygen isotope content of the carbonate and the temperature $(6 \circ \mathrm{or})$ are known, the isotopic composition of the water with which it was in equilibrium at the time of formation can be determined. Similar calculations can be made for clay minerals.

For carbon isotope fractionation in the carbonate system, where precise calculations are needed, data presented by Deines, Langmuir, and Harmon (1974) will be utilized. Where 


$$
\begin{aligned}
\mathrm{K}_{0} & =\frac{\mathrm{R}_{2} \mathrm{CO}_{3}}{\mathrm{R}_{\mathrm{CO}_{2}}}, \\
\mathrm{~K}_{1} & =\frac{\mathrm{R}_{\mathrm{HCO}_{3}^{-}}}{\mathrm{R}_{\mathrm{CO}_{2}}}, \\
\mathrm{~K}_{2} & =\frac{\mathrm{R}_{\mathrm{CO}_{3}^{-2}}}{\mathrm{R}_{\mathrm{CO}}}, \text { and } \\
1000 \text { In } \mathrm{K}_{3} & =3.63+1.194 \frac{10^{6}}{\mathrm{R}_{\mathrm{CaCO}}}=\frac{\mathrm{T}^{2}}{\mathrm{R}_{\mathrm{CO}}}, \\
1000 \text { In } \mathrm{K}_{2} & =-3.4+0.879 \frac{10^{6}}{\mathrm{~T}^{2}}, \text { and } \\
1000 \text { In } \mathrm{K}_{1} & =-4.54+1.099 \frac{10^{6}}{\mathrm{~T}^{2}}, \\
& =0.91+0.0063 \frac{10^{6}}{\mathrm{~T}^{2}},
\end{aligned}
$$

where $\mathrm{T}$ is in degrees Kelvin (oK).

The isotope geochemistry of clay minerals has been studied by Savin (1967), Savin and Epstein (1970), Lawrence (1970) and O'Neil and Kharaka (1976) to mention a few. These studies lead to the conclusion that clay minerals formed in equilibrium with waters under sedimentary conditions maintain their isotopic composition in a low-temperature environment (less than $100 \circ \mathrm{O})$. At $100 \mathrm{oC}$ hydrogen exchange has been noted in clays. The exchange rate for smectites (montmorillonite) is 3 to 5 times that for illite and kaolinite (0'Neil and Kharaka, 1976). O'Neil and Kharaka (1976) 
further state that clays formed by surficial weathering will not evidence post-formation exchange of hydrogen unless the isotopic composition of meteoric waters changed radically and that except possibly for smectite minerals, oxygen isotope exchange is negligible. Their study and a study by James and Baker (1976) at 22 oC utilizing illite indicate that oxygen isotope exchange is a function of the accessibility of water to the interlayer positions. This suggests that interlayer illite/smectite and smectite minerals will be much more susceptible to oxygen exchange than we11crystalized illites or kaolinites. Under sedimentary conditions if exchange occurs it is unlikely to achieve equilibrium unless significant chemical and structural changes occur (James and Baker, 1976).

Savin (1967) reports fractionation factors for clay minerals as follows:

Fractionation factors between clay minerals and water at 25 oC

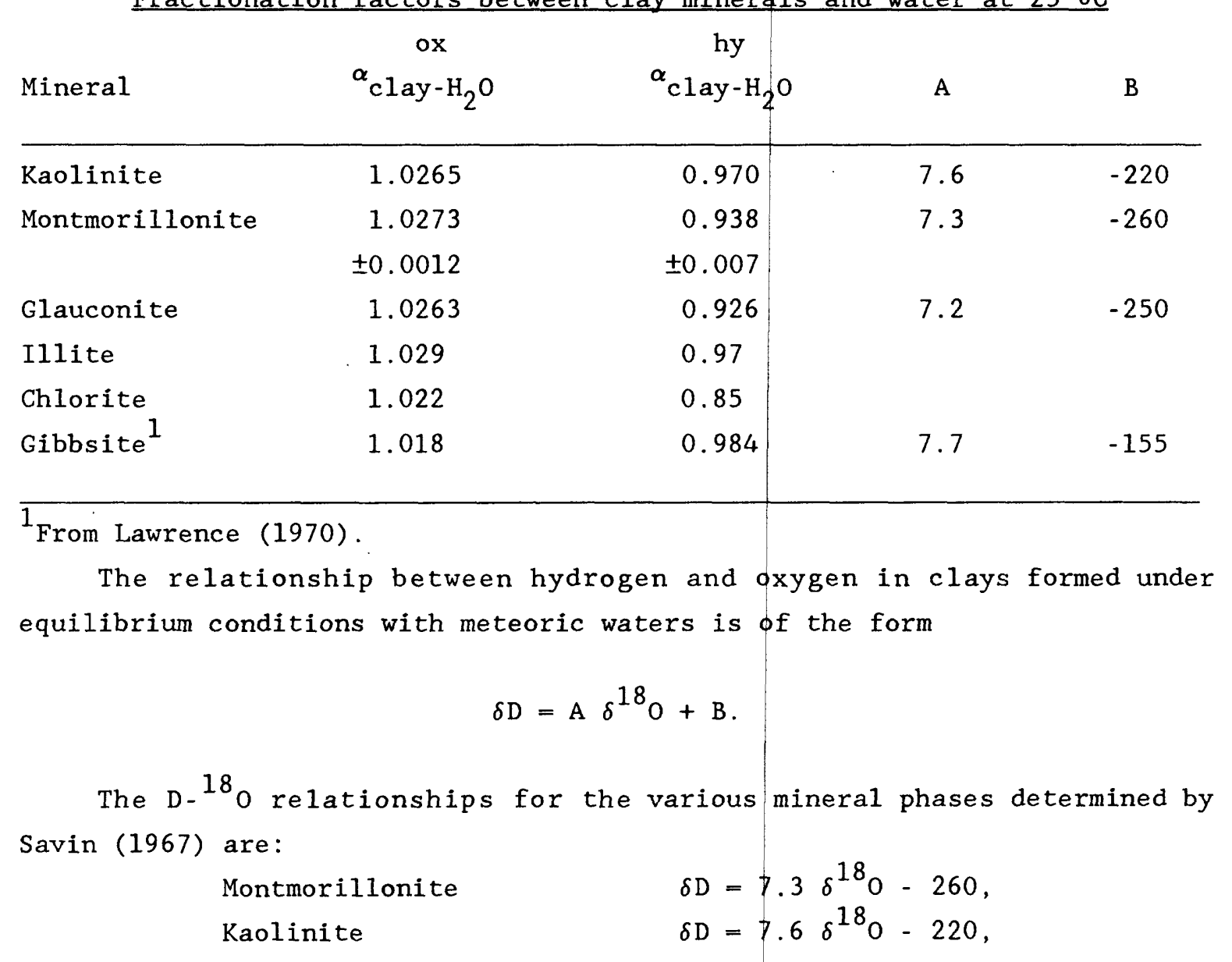




$$
\begin{array}{ll}
\text { Glauconite } & \delta \mathrm{D}=7.2 \delta^{18} \mathrm{O}-250, \text { and } \\
\text { Gibbsite } & \delta \mathrm{D}=7.7 \delta^{18} \mathrm{O}-155 .
\end{array}
$$

Gibbsite determination from Lawrence (1970).

Redox reactions cause the most significant isotope fractionations. The fractionation factor for $\mathrm{CO}_{2}-\mathrm{CH}_{4}$ formed in equilibrium at 25 oC is $1.070 \%$ with the $\mathrm{CO}_{2}$ enriched and the $\mathrm{CH}_{4}$ depleted in ${ }^{13} \mathrm{C}$. Usually most observed redox fractionation reactions are assisted by microbial reduction. Uncatalyzed chemical reduction does occur, but usually with very slow reaction rates. The presence of micro-organisms in the system may significantly enhance the reaction.

One biochemical fractionation process worth mentioning involves the fixation of $\mathrm{CO}_{2}$ during photorespiration. The common Calvin Cycle (C-3 pathway) plants fractionate atmospheric $\mathrm{CO}_{2}\left(\delta^{13} \mathrm{C}\right.$ value of $-7 \%$ oo $)$ by utilizing the depleted $\mathrm{CO}_{2}$ in the plant structure $\left(\delta^{13} \mathrm{C}\right.$ of approximately $-25 \%$ oo). Some plants grown in stressed environments, such as deserts, salt marshes, and the tropics, are more efficient users of $\mathrm{CO}_{2}$ and do not fractionate the carbon nearly as much. These plants are not as selective of the mass of the $\mathrm{CO}_{2}$ molecule incorporated into the structure and the overall plant is more enriched in ${ }^{13} \mathrm{C}$. These plants utilize the Hatch-Slack or $\mathrm{C}-4$ pathway of carbon fixation and have $\delta^{13} \mathrm{C}$ values as heavy as $-12 \%$.

\section{PALEOTEMPERATURE DETERMINATIONS}

Because fractionation factors among various mineral phases and water are all temperature dependent, it is possible to calculate the temperature of the solution from which a mineral precipitated if the isotopic composition of the water is known, assuming isotopic equilibrium, or to calculate the isotopic composition of the water, if the isotopic composition of the mineral is known, and temperature is assumed. This process can be utilized to attempt to determine the paleoclimatic environment of an area by making we1l-defined assumptions. 
By taking the oxygen-isotope composition of secondary carbonate minerals developed in the sediment horizons it may be possible to make an estimate of the oxygen-isotope composition of the water from which that material precipitated. Likewise, by taking the oxygen-isotope composition of secondary silica observed it may be possible to calculate the isotopic composition of the water. If it is felt that these two minerals precipitated at about the same time, it may then be possible to cross-check the environment of formation of the secondary minerals.

\section{$\mathrm{X}$-RAY ANALYSES}

Sample preparations to yield less than $1 \mu \mathrm{m}$ fraction utilized for $\mathrm{X}$-ray analysis and for the clay oxygen-18 analysis were conducted by the set of procedures established fy Janet Hoffman (oral commun., 1976) for the U.S. Geological Survey's mineral-water interaction laboratory located at Reston, Virginia. The X-ray slides of the less than $1 \mu \mathrm{m}$ material were run on a Norelco $X$-ray Diffractometer using CuK radiation. The percentage of clay minerals was determined using techniques described by Schultz (1964). Approximations of the percent expandable layers in the mixed layer, illitesmectite (I/S), clays were determined using techniques of Reynolds and Hower (1970). Oriented samples were run untreated, saturated with ethylene glycol, and heated to 350 oC for half an hour.

\section{ISOTOPE ANALYSES}

Clay samples for isotope analysis were separated as described in a previous section and the oxygen extracted utilizing bromine pentafluoride equipment by R.O. Rye in the U.S. Geological Survey's laboratory located at Denver, using the techniques of Clayton and Mayeda (1963). The oxygen thus extracted was converted to $\mathrm{CO}_{2}$ and analyzed for ${ }^{18} 0$ content by mass spectrometer by C.T. Rightmire in the U.S. Geological Survey's laboratory located at Reston, Virginia. 
The carbonate samples were prepared by reacting the solid carbonate with 100 percent phosphoric acid (McCrea, 1950). The $\mathrm{CO}_{2}$ thus liberated was analyzed for ${ }^{13} \mathrm{C}$ and ${ }^{18} \mathrm{O}$.

Water samples were analyzed in the laboratory of L. Merlivat, Centre d'Etudes Nuclaires de Saclay, Gif-Sur-Yvette, France, for both $D$ and ${ }^{18} 0$ analyses.

\section{SUMMARY}

This report describes the cored material and subpit sedimentary samples, and documents the sample preparation and analytical techniques used to characterize the hydrogeologic and geochemical environment of the unsaturated zone at the Radioactive Waste Management Complex, Idaho National Engineering Laboratory, on the eastern Snake River Plain in southeastern Idaho. This characterization is needed to develop a conceptual model of the hydrogeochemical environment of the shallow unsaturated $z$ one, and to determine how changes in that environment may influence the mobility and migration of waste radionuclides buried in pits and trenches at the facility between the early 1950's and the early 1970's.

Visual and optical inspections of cored material collected from 8 wells drilled during a 1976-1977 drilling program, along with subpit sedimentary samples, provided the needed hydrogeologic data. A sequence of at least 13 basalt flows or flow units and 3 interflow sedimentary beds have been identified between land surface and about $183 \mathrm{~m}$ in boreholes drilled at the RWMC. The 3 interflow sedimentary beds were observed at depths of 9,34 , and 73 meters. These sedimentary deposits are composed largely of fine sand, silt, and clay.

Sample preparation and analytical techniques were required that would provide the needed information on geochemical characteristics of the unsaturated zone. Analytical procedures were established following an intensive literature search and information was collected on the following topics: Geochemical use of stable isotope data; Standards and $\delta$ notation; 
Fractionation factors; Natural fractionation; Paleotemperature determinations; X-ray analyses; and Isotope analyses.

\section{REFERENCES}

Barraclough, J.T., Robertson, J.B., and Janzer, V.J., 1976, Hydrology of the solid waste burial ground, as related to the potential migration of radionuclides, Idaho National Engineering Laboratory, with a section on Drilling and sample analyses, by L.G. Saindon: U.S. Geological Survey Open-File Report 76-471, IDO-22056, 183 p.

Burgus, W.H., and Maestas, S.E., 1976, The 1975 RWMC core drilling program, a further investigation of subsurface radioactivity at the Radioactive Waste Management Complex, Idaho National Engineering Laboratory: U.S. Energy Research and Development Administration, Office of Waste Management, Idaho Operations Office Publication, IDO-10065, 36 p.

Clayton, R.N., and Mayeda, T., 1963, The use of bromine pentafluoride in the extraction of oxygen from oxides and silicates for isotopic analysis: Geochimica et Cosmochima Acta, v. 27, p. 43-52.

Coplen, T.B., and Clayton, R.N., 1973, Hydrogen isotopic composition of NBS and IAEA stable isotope water reference samples: Geochimica et Cosmochima Acta, v. 37, p. 2346-2349.

Craig, Harmon, 1961a, Isotopic variations in meteoric waters: Science, v. 133, p. $1702-1703$.

-. - 1961b, Standard for reporting concentrations of deuterium and oxygen-18 in natural waters: Science, v. 133, p. 1833-1834.

Deines, Peter, Langmuir, Dona1d, and Harmon, R.S., 1974, Stable carbon isotope ratios and the existence of a gas phase in the evolution of carbonate ground waters: Geochimica et Gosmochima Acta, v. 38, p. 1147-1164.

Friedman, Irving, and O'Neil, J.R., 1977, Compilation of stable isotope fractionation factors of geochemical interest: U.S. Geological Survey Professional Paper 440-KK, 109 p.

Humphery, T.G., and Tingey, F.H., 1978, The subsurface migration of radionuclides at the Radioactive Waste Management Complex, 1976-1977: U.S. Department of Energy, Idaho Operations Office Publication, TREE 1171, 98 p.

James, A.T., and Baker, D.R., 1976, Oxygen isotope exchange between illite and water at 25 oC: Geochimica et Cosmochima Acta, v. 40, p. 235-240.

Kuntz, M.A., 1978a, Geology of the Arco-Big Southern Butte area, eastern Snake River Plain, and volcanic hazards to the Radioactive Waste Management Complex, and other waste storage and reactor facilities at the Idaho National Engineering Laboratory, Idaho, with a section on 
statistical treatment of the age of lava flows, by J.0. Kork: U.S. Geological Survey Open-File Report 78-691, 70 p.

Kuntz, M.A., Dalrymple, G.B., Champion, D.E., and Doherty, D.J., 1980, Petrography, age, and paleomagnetism of volcanic rocks at the Radioactive Waste Management Complex, Idaho National Engineering Laboratory, Idaho, with an evaluation of potential volcanic hazards: U.S. Geological Survey Open-File Report, 80-388, 63 p.

Lawrence, J.R., 1970, ${ }^{18} \mathrm{O} /{ }^{16} \mathrm{O}$ and $\mathrm{D} / \mathrm{H}$ ratios of soils, weathering zones and clay deposits: California Institute of Technology, Pasadena, Unpublished $\mathrm{PhD}$. Thesis, $263 \mathrm{p}$.

Lewis, B.D., and Goldstein, F.G., 1982, Evaluation of a predictive groundwater solute-transport model at the Idaho National Engineering Laboratory, Idaho: U.S. Geological Survey Water Resources Investigation $82-25,71 \mathrm{p}$.

McCrea, J.M., 1950, The isotopic chemistry of carbonates and a paliotemperature scale: Journal of Chemical Physics, v. 28, p. 849-857.

O'Neil, J.R., and Kharaka, Y.K., 1976, Hydrogen and oxygen isotope exchange reactions between clay minerals and water: Geochimica et Cosmochima Acta, v. 40, p. 241-246.

Reynolds, R.C., Jr, and Hower, John, 1970, The nature of interlayering in mixed-layer illite-montmorillonites: Clays and Clay Minerals, v. 18, p. $25-36$.

Rightmire, C.T., 1984, Description and hydrogeologic implications of cored sedimentary material from the 1975 drilling program at the Radioactive Waste Management Complex, Idaho: U.S. Geological Survey WaterResources Investigations Report 84-4071, 33p.

Robertson, J.B., Schoen, Robert, and Barraclough, J.T., 1974, The influence of liquid waste disposal on the geochemistry of water at the National Reactor Testing Station, Idaho, 1952-1970: U.S. Geological Survey Open-File Report IDO-22053, 231 p.

Savin, S.M., 1967, Oxygen and hydrogen isotope ratios in sedimentary rocks and minerals: California Institute of Technology, Pasadena, Unpublished Ph.D. Thesis, $220 \mathrm{p}$.

Savin, S.M., and Epstein, Samuel, 1970, The oxygen and hydrogen isotope geochemistry of clay minerals: Geochimica et Cosmochima Acta, V. 34, p. $25-42$.

Schultz, L.G., 1964, Quantitative interpretation of mineralogic composition from X-ray and chemical data for the Pierre Shale: U.S. Geological Survey Professional Paper 391-C, 31 p. 


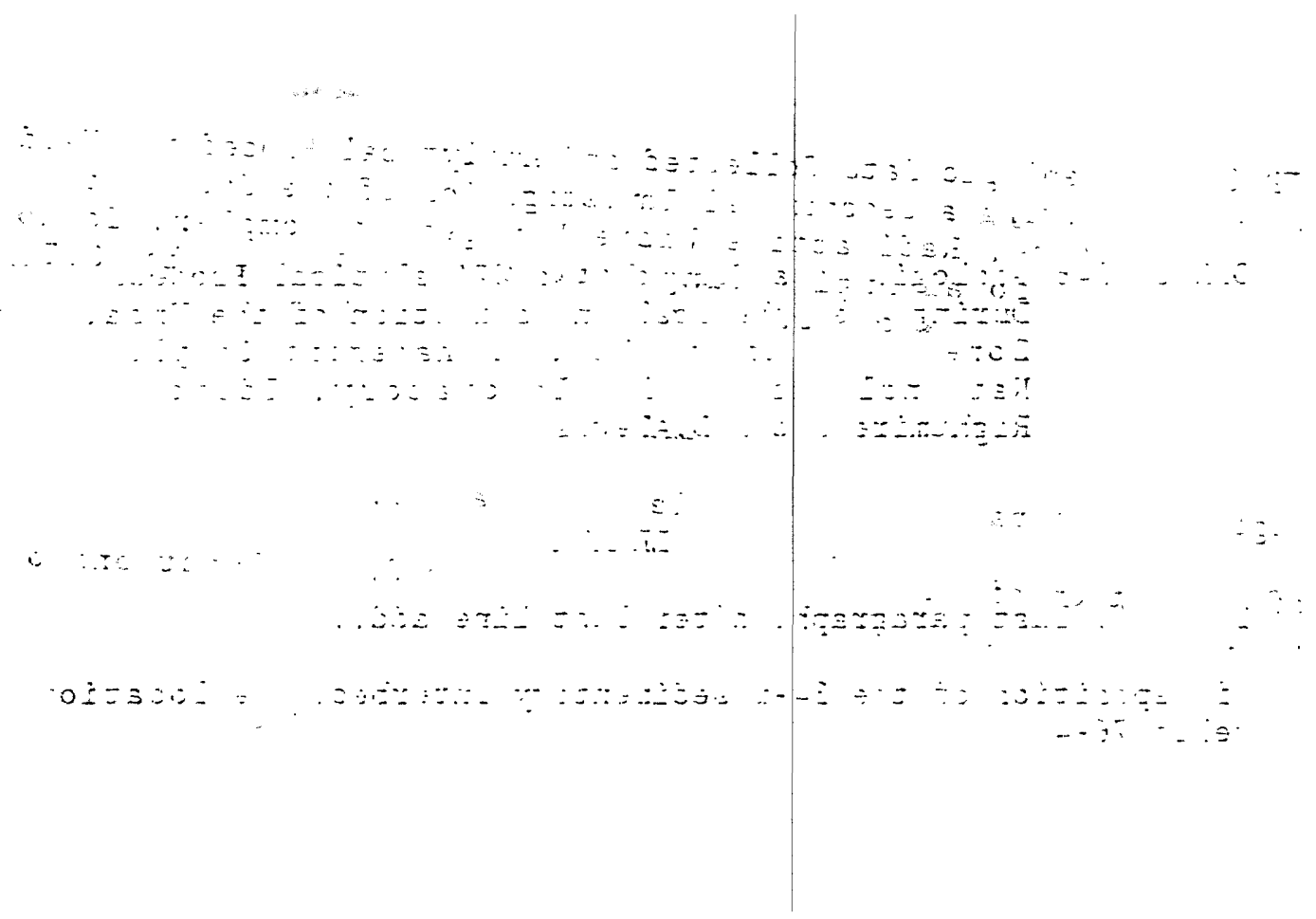


OFR 87-246 Geologic Data Collected and Analytical Procedures Used During a Geochemical Investigation of the Unsaturated Zone, Radioactive Waste Management Complex, Idaho National Engineering Laboratory, Idaho, by C.T. Rightmire and B.D. Lewis

\section{ERRATA}

Page 64, last paragraph, after last line add...

of deposition of the 34-m sedimentary interbed, the locations of wells $76-4$ 